\title{
AS MULHERES E SUAS DECISÕES REPRODUTIVAS, DIANTE DA EPIDEMIA DE HIV/AIDS
}

\section{NAILA JANILDE SEABRA SANTOS}

Tese apresentada ao Departamento de Epidemiologia da Faculdade de Saúde Pública da Universidade de São Paulo para obtenção do título de Doutor em

Saúde Pública

Área de Concentração: Epidemiologia

Orientador: Prof. Dr. Ruy Laurenti

São Paulo 
A todas as mulheres;

que têm filhos ou não; que são portadoras do HIV ou não 


\section{AGRADECIMENTOS}

Ao meu orientador. Dr. Ruy Laurenti, por ter me acolhido como orientanda, após o falecimento do Dr. Edmundo Juarez, por sua compreensão e apoio para realização deste trabalho.

Ao Dr. Edmundo Juarez, em memória

À Dra. Cássia M. Buchalla, por sua co-orientação tão amiga.

A Dra. Vera Paiva, com quem compartilhei a realização da pesquisa com as mulheres, pelo seu jeito especial e humano de ser pesquisadora.

Às outras profissionais que participaram da pesquisa com as mulheres: Betina Leme, Letícia Tunala, Tayra Lopes, Regiane Nigro, Laura Bugamelli, Sonia Garcia e Rebecca Plank e ao suporte financeiro e parceria com os cientistas Arthur Reingold da Fogarty International AIDS Training e Norman Hearst do Center for AIDS Prevention Studies at the University of California at San Francisco.

Ao Dr. Ivan França Jr., por suas valiosas sugestões para a análise e aprimoramento deste trabalho.

À Dra. Bernadete Waldvogel, pela sua leitura e sugestões, e pela agradável parceria de trabalho que ela nos proporciona, sempre.

À Dra. Denise P. Bergamaschi e à Dra. Maria do Rosário D. O. Latorre que, muito gentilmente, me orientaram na análise dos dados. 
A Enf. Angela Tayra, pelo seu auxílio tão carinhoso e competente.

A Dra lone Aquemi, pelas explicações e sugestões na reta final da análise dos dados.

A Dra. Emily Anna C. Ruiz, pelo apoio de sempre e pela tradução, para o inglês, do resumo deste trabalho.

A Enf. Sirlene Caminada, pelo presente de um livro sobre o tema, auxiliando, como ela sempre faz, minha reflexão no trabalho

À minha irmã, Prof. Naira J. S. Santos, pela revisão gramatical desta tese e pela sua disposição de estar, sempre, me ensinando os porquès da língua portuguesa.

Aos amigos: Dr. Paulo Roberto Teixeira, Dr. Artur O. Kalichmann, Dra Maria Clara Gianna, Alexandre Grangeiro, Rosemeire Munhoz e Josefa Laurindo pelos muitos anos de jornada juntos, no trabalho com DST/AIDS.

Às minhas companheiras na Vigilância Epidemiológica de DST/AIDS: Sirlene, Ângela, Marisa, Ana Lúcia , Nanci, Emily Anna, Ione Aquemi, Marta Ramalho, Elisa, Sara, Leda Fátima, Carmen Silvia, Berenice, Altamira, Eliana, Magda e Júlia, pelo respeito, carinho e seriedade com que cada uma conduz nosso trabalho, tornando-o, para mim, uma fonte de realização

À Sonia Regina, bibliotecária do CRT-DST/AIDS, por sua solicitude e auxilio nos levantamentos bibliográficos.

À Dra. Regina Barbosa, por suas sugestões de bibliografia.

A Maria José e a Núbia, companheiras de trabalho, que muitas vezes nos últimos tempos, "seguraram a minha barra" no ambulatório da CETESB, para que eu finalizasse este trabalho. 
A minha mãe. Yvonne, pelo estimulo e orgulho que demonstra de sua filha médica que, se Deus quiser, e os julgadores da banca concordarem. em breve sera doutora

Ao meu pai, Antonio, em memória.

Ả minha Tia Leticia, minhas irmãs Najla, Naira, Nadja, Naida e Cássia e meus (minhas) sobrinhos(as) pela nossa união e pelo apoio.

Aos meus filhos, Guilherme, Rafael e Ana Clara, que muitas vezes me atrapalharam docemente, mas que são, sempre, o estímulo maior da minha vida.

Ao meu marido, Sérgio Giannella, pelo apoio logistico com as crianças e na finalização de cada etapa da tese, e por seu carinho, que torna tudo melhor.

$\mathrm{E}$, por fim, agradeço, sincera e especialmente, às mulheres que participaram desta pesquisa e, que, a ela emprestaram suas experiências. 


\section{Resumo}

Introdução: A epidemia de AIDS tem crescido rapidamente entre as mulheres no nosso meio, como se vê no perfil epidemiológico da AIDS em São Paulo elaborado neste trabalho. A feminização da epidemia traz a tona várias discussões especificas do gênero feminino. Objetivos: Estudar as questões relativas a saúde reprodutiva de mulheres HIV positivas, seu desejo de ter filhos e as variáveis a ele associadas. Método: Estudo exploratório com entrevista de 148 mulheres HIV positivas, atendidas em ambulatório especializado. Resultados: O desejo de ter filhos não se altera substancialmente nas mulheres em conseqüência da infecção pelo HIV. Um maior número de filhos, filhos vivos e filhos que moram com as mães são fatores que interferem negativamente no desejo de ter filhos. Não foi encontrada associação deste desejo com outras variáveis como percepção de risco, situação sorológica do parceiro, uso de contraceptivos, e outros. Conclusão: Mulheres HIV positivas precisam ter seus direitos reprodutivos e sexuais discutidos e respeitados em todos os serviços de atenção à sua saúde. São necessários serviços que promovam um ambiente de suporte para estas discussões às mulheres e a seus parceiros, propiciando às pessoas vivendo com HIVIAIDS condições de realizar opções conscientes no que concerne a sexualidade e às decisões reprodutivas.

Descritores: Mulheres, direitos reprodutivos, contracepção, HIV, AIDS. 
Abstract

Introduction: The AIDS epidemic has been increasing faster in women than in men, as shown by the profile AIDS epidemic in the State of Sao Paulo. Objectives: To study the reproductive health needs of HIV positive women, and the wish of them to have children. Methods: We interviewed 148 HIV positive women, to know what they had to say about reproductive life and others factors even associated. Results: The wish of have children seems do not change with HIV infection. The number of children, number of alive children and the fact of they live with their mothers modify the wish of maternity. There is no association between wish and risk perception, partners sorologic status, contraceptive use and others factors. Conclusion: HIV positive women need to have their sexual and reproductive rights discussed and respected. Services fostering supportive environment to open up discussion on reproductive rights of HIV positive people are urgently needed.

Descriptors: Women, reproductive rights, risk perception, contraception, HIV, AIDS. 


\section{ÍNDICE}

página

\section{INTRODUÇÃO}

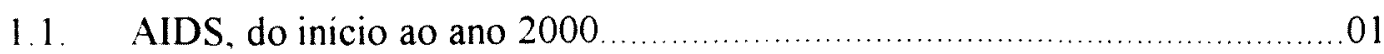

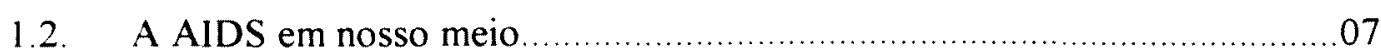

1.2.1. Perfil da epidemia de AIDS no Estado de São Paulo ..................................08

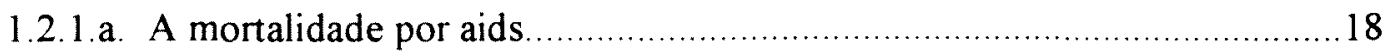

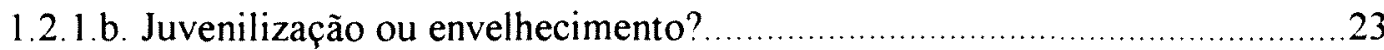

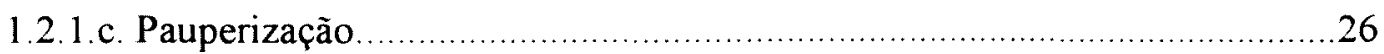

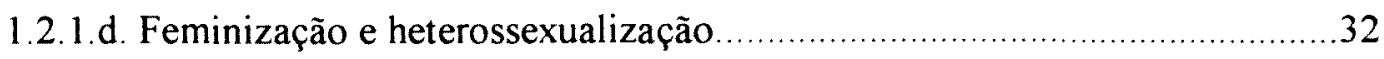

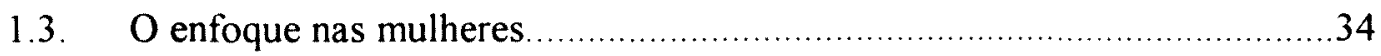

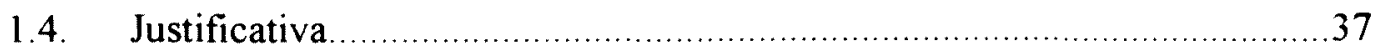

\section{OBJETIVOS}

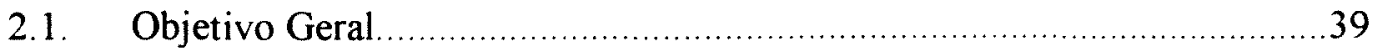

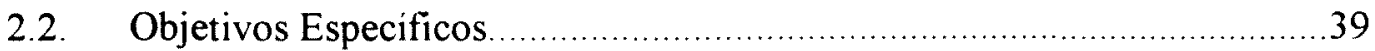

\section{MÉTODO}

3.1. Pesquisa realizada com 148 mulheres soropositivas para o HIV ...............40 


\section{RESULTADOS}

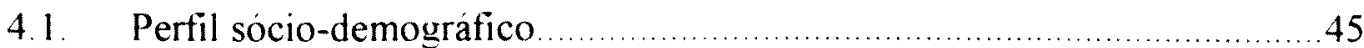

4.2. Número de parceiros sexuais e atividade sexual destas mulheres.............47

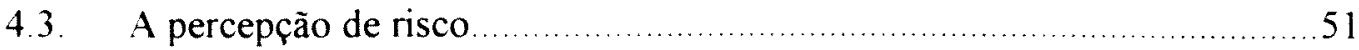

4.4. Contracepção, proteção dupla e planejamento familiar ..........................53

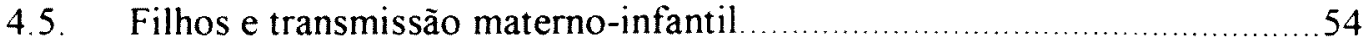

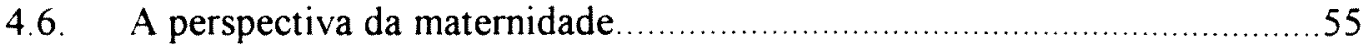

4.7. Estímulo para viver e possibilidade de faltar aos filhos........................61

5. DISCUSSÃO

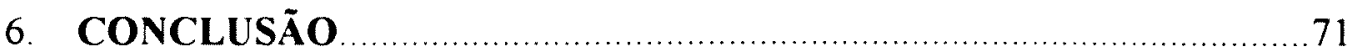

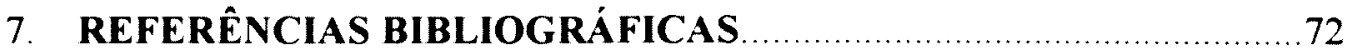




\section{INTRODUÇÃO}

\subsection{AIDS, do início ao ano 2000}

Os primeiros casos da Síndrome da Imunodeficiència Adquirida - AIDS ou aids como se denomina atualmente no Brasil, foram descritos em $1981(26,38)$ e, ainda que naquele momento não se conhecesse sua causa, a nota editorial que acompanhava a publicação sugeria "uma disfunção da imunidade celular relacionada a uma exposição comum" e "uma patologia adquirida por contato sexual" (25) . Na primeira metade da década de 80 o virus da imunodeficiência humana (HIV) foi isolado e relacionado à $\operatorname{AIDS}(10,34)$.

Embora inicialmente vinculado aos homens que fazem sexo com outros homens (HSH), particularmente nos paises industrializados e na América Latina, o HIV se disseminou rapidamente entre os diversos segmentos da sociedade alcançando paulatinamente mulheres, crianças e homens com prática heterossexual.

Essa disseminação se deu não só, embora principalmente, pela via sexual $(23,32,66)$, mas também pela via sangǘnea, através do compartilhamento de seringas e agulhas por usuários de drogas injetáveis e das transfusões de sangue e hemoderivados e, ainda, pela via materno-infantil (transmissão da mãe para a criança na gestação, parto ou durante o aleitamento materno), na medida em que as mulheres foram sendo atingidas pela epidemia.

No inicio da epidemia, quando não havia um controle efetivo da qualidade do sangue no que concerne à sua contaminação pelo HIV, uma grande parcela da população de transfundidos e hemofilicos foi atingida. Hoje a probabilidade deste tipo de transmissão é bem menor, dado ao controle de qualidade do sangue estabelecido em vários paises (56). Em estudo realizado na Fundação PróSangue/Hemocentro de São Paulo, o risco residual de transmissão do HIV, via transfusão sangüínea, foi estimado em 1,56 por 100.000 doações, e este valor é cerca de 10 vezes maior do que o estimado para os Estados Unidos da América (EUA) e Europa (82). 
Pode-se perceber diferentes padrões de transmissào da infecção pelo HIV obedecendo a distintas formas de organizaçào social $(11.24,63.76)$. No continente africano, as principais formas de transmissào do HIV sempre foram as relações heterossexuais e a transmissão materno-infantil. Na Europa Ocidental, EUA e em varios paises da America Latina, apesar da relevància dos $\mathrm{HSH}$, particularmente nos primórdios da epidemia. o compartilhamento de seringas e agulhas por usuarios de drogas injetáveis surgiu como uma importante forma de disseminação do HIV.

No Estado de São Paulo, os padrões de transmissão são distintos nas diversas regiões do Estado (87) e, também em nosso meio, o compartilhamento de seringas e agulhas pelo uso de drogas injetáveis destaca-se enquanto forma de disseminação da infecção pelo $\mathrm{HIV}$, tendo se constituido em um modo bastante eficiente de atingir a população heterossexual, através da alta porcentagem de individuos que se infectaram pela parceria sexual com usuários(as) de drogas injetáveis $(85,88)$.

Assim, se no início a infecção pelo HIV parecia limitar-se a determinados "grupos de risco" compostos por homossexuais, hemofilicos e usuários de drogas, com o correr do tempo ela foi buscando caminhos e tomando espaços na população geral $(27,32)$ e "socializando" a sua possibilidade de ocorrência, que antes parecia restrita aos "diferentes e famosos", levando progressivamente à pauperização $(11,13,53,73,80,94)$ e feminização $(12,24,70,78,85)$ da epidemia.

Em poucos anos a infecção pelo HIV transformou-se em uma pandemia A Organização Mundial de Saúde (OMS) estima que, do inicio da epidemia até dezembro do ano $2000,36,1$ milhões de pessoas em todo o mundo contrairam o HIV (com aproximadamente 20 milhões de óbitos), sendo destas 34,7 milhões de adultos e 1,4 milhões de menores de 15 anos, ressaltando-se que 80 a $90 \%$ das infecções em crianças são decorrentes da transmissão materno-infantil

Estima-se que só no ano 2000,3 milhões de pessoas evoluiram para óbito por AIDS, destas 1,3 milhões eram mulheres e 500.000 menores de 15 anos de idade e que, aproximadamente, 1 em cada 100 adultos entre 15 e 49 anos apresentase infectado, dos quais $43 \%$ são mulheres (esta proporção cresce dia a dia), e ainda, a imensa maioria destas infeç̧ões ocorrem nos paises em desenvolvimento (50). 
Tendo atingido particularmente a populaçào de adultos jovens em todo o mundo, a AIDS foi responsável por milhares de APVP (Anos Potenciais de Vida Perdidos) do final dos anos 80 a meados dos 90 . levando em varias localidades a uma diminuição significativa da esperança de vida. e aparecendo como a principal causa de mortalidade para a população entre 15 e 49 anos em inúmeros paises. inclusive no Brasil No Municipio de São Paulo. em 1995 a AIDS foi a segunda causa na hierarquização dos APVP para os homens e a primeira para as mulheres (60).

$\mathrm{Na}$ África sub-saariana, onde se vive a mais grave epidemia de HIV, estão as 21 maiores taxas de prevalència do mundo Em 13 paises africanos, pelo menos, $10 \%$ da população adulta está infectada pelo HIV , e as taxas de prevalência em muitas capitais são de $35 \%$ ou mais. Botswana e Zimbabwe tem apresentado uma prevalência de $25 \%$ da população, isto é, um em cada quatro adultos está infectado Na Namibia, a AIDS provoca o dobro das mortes por malária. a segunda causa mais comum de mortalidade naquele pais

A crescente desigualdade entre os paises desenvolvidos e os em desenvolvimento se reflete tanto na magnitude da propagação do HIV quanto na mortalidade por AIDS. Na medida em que se acentuam as diferenças de acesso ao tratamento, a mortalidade por AIDS diminui nos paises mais ricos e aumenta nos paises mais pobres (51), exceção feita ao Brasil, que é um dos poucos paises do mundo que adotaram a política de distribuição gratuita de antiretrovirais aos portadores de HIV/AIDS

Em alguns paises da África, a esperança de vida retrocedeu na década de 90 aos niveis da década de 60. Em Zimbabwe, a mortalidade entre crianças de 1 a 5 anos de idade passou de 8/1000 a 20/1000 entre 1988 e 1996. Entre os africanos orientais, a AIDS mais do que duplicou a mortalidade dos adultos nas zonas rurais, onde quase $10 \%$ da população é HIV positiva, e é a causa de 4 em cada 5 óbitos de pessoas entre 25 e 34 anos

No entanto, apesar do panorama sombrio, alguns paises africanos tèm conseguido uma diminuição das taxas de infecção pelo HIV claramente vinculadas a programas de prevenção sólidos com a promoçào do uso de condom, regulamentação do sexo comercial, tratamento de doenças sexualmente transmissiveis e mobilização da comunidade. Uganda conseguiu reduzir a prevalència de HIV de quase $13 \% \mathrm{em}$ 
1994 a 9.5\% em 1997. In Masaka. Uganda. a prevalència de HIV em mulheres de 20 a 24 anos decresceu de 20,9\% em 89/90 a 13.8\% em 96/97. Na Zàmbia, em mulheres assistidas em clínicas de pré-natal, de 15 a 19 anos. a soroprevalència passou de 27\% em 1993 a 17\% em 1998 (24). Mesmo no mundo industrializado não se tem uma redução desta magnitude, calcada em programas de prevenção

$\mathrm{Na}$ Ásia, América Latina e Europa Oriental, apesar de apresentarem taxas baixas de prevalência, há uma sub-notificação importante e, segundo estimativas da OMS. em muitos paises o número de casos deve ser multiplicado por dois ou por três para nos aproximarmos do real.

Com mais de $90 \%$ das pessoas infectadas pelo HIV vivendo em paises em desenvolvimento, onde há poucos serviços para atender à demanda da população, a UNAIDS (Joint United Nations Programme on HIV/AIDS) estima que 9 entre cada 10 pessoas infectadas não conhecem seu estado sorológico

$\mathrm{Na}$ Ásia, que acolhe a metade da população do planeta, embora a AIDS só tenha aparecido no fim dos anos 80 , começo dos 90 , na atualidade já ocorre uma de cada cinco infecções do mundo. $\mathrm{Na}$ Índia, embora a proporção conhecida de individuos infectados esteja abaixo de $1 \%$, se estima que 4 milhões de pessoas vivem com HIV

Na Europa Oriental, a propagação da infecção pelo HIV observada em vários paises está estreitamente ligada ao consumo de drogas, e explica a maior parte dos 100.000 casos novos estimados em 1997. Ao mesmo tempo o alto número de doenças sexualmente transmissiveis, que se observa na Rússia e outros paises da região, aumenta a preocupação com relação ao potencial de propagação sexual (52).

A AIDS cresceu em todo o mundo mas, nos últimos anos, nos países desenvolvidos, há uma tendência a queda dos óbitos por esta doença. Numerosos paises industrializados e alguns poucos paises em desenvolvimento, entre os quais o Brasil, tèm conseguido modificar o perfil de mortalidade da epidemia, o que, até bem pouco tempo atrás, parecia praticamente impossivel.

Nos Estados Unidos da América (EUA) em 1996, houve pela primeira vez uma diminuição dos casos anuais de AIDS (6\%), e a mortalidade por esta doença caiu $26 \%$ entre $95(15,6 / 100.000)$ e $96(11,6 / 100.000)$. Antes, a mortalidade aumentava em média 16\% ao ano de 87 a 94, até começar a declinar em 95. De 1996 
a 1997. as taxas de mortalidade pela infecção pelo HIV nos EUA tiveram um declinio sem precedentes de $47 \%$. e. no mesmo periodo. a infeç̧ão pelo HIV caiu do oitavo ao $14^{\circ}$ lugar entre as principais causas de mortalidade (22). Para a idade de 2544 anos as doenças relacionadas ao HIV cairam da primeira causa de mortalidade em 95. para a terceira em 96 e a quinta em 97

Entretanto. nas populaçōes minoritárias. negros e hispànicos, o número de casos continua aumentando

De acordo com o CDC (Centers for Disease Control and Prevention), os dados sugerem que, enquanto as taxas de mortalidade decrescem drasticamente, o número anual de novas infecções pelo HIV nos EUA não tem decrescido nos últimos anos, e a combinação destes dois fatores, o decréscimo da mortalidade e o aumento e/ou manutenção da incidència, tem aumentado o número total de pessoas vivendo com HIV/AIDS

Na Europa Ocidental, América do Norte, Austrália e Nova Zelândia a terapia anti-retroviral está retardando o aparecimento da AIDS nas pessoas infectadas pelo HIV Na Europa Ocidental os dados disponiveis mostram uma diminuição de cerca de 30\% dos casos novos de AIDS em 1997, com relação a 1995, ano em que ainda não se dispunha de antiretrovirais para o tratamento que prolonga a vida e a condição de soropositivo assintomático dos pacientes.

Quanto às taxas de mortalidade, elas têm diminuido desde setembro de 1995 na Europa e, no inicio de 1998 eram menores do que um quinto de seus niveis anteriores (no periodo de 1994 a 1995). Esta diminuição da mortalidade pode ser explicada em grande parte pelo uso de novas terapias antiretrovirais ou pela combinação destas (69). Entretanto, esta diminuição da mortalidade não tem sido acompanhada de uma queda na incidência da infeç̧ão pelo HIV, reiterando a idéia de que cresce, no mundo, a prevalência de pessoas vivendo com HIV/AIDS (32).

É fundamental observar que diversos outros fatores são capazes de influenciar o tempo e a qualidade de vida dos individuos com HIV/AIDS.

O acompanhamento laboratorial e o manejo clínico cuidadoso e adequado dos individuos HIV positivos por clínicos treinados e eficientes, a quimioprofilaxia e tratamento de determinadas infecções oportunistas que aumentam o risco de evolução fatal $(28,79)$, a compreensão dos fatores constitucionais e o 
acompanhamento psicológico dos pacientes (18), sào todos aspectos fundamentais a serem considerados, sem os quais, a administração pura e simples da terapêutica anti-retroviral não será suficiente para mudar o prognóstico da infecção pelo HIV Observe-se que, mesmo antes da instituição desta terapèutica, a sobrevida dos pacientes já era maior nos paises industrializados do que nos paises em desenvolvimento

Os avanços da terapia anti-retroviral e as tendências atuais da epidemia, concentrando-se em paises e populações mais socialmente vulneráveis (68), devem levar a novas reflexões sobre as formas de abordagem do HIV/AIDS sob suas diversas nuanças, que vão desde o manejo clínico e psicológico dos pacientes já infectados, diante da possibilidade de prolongamento de suas vidas na condição de soropositivos assintomáticos para o HIV, até a implementação e manutenção de politicas públicas de prevenção e assistência cada vez mais eficientes, com o desafio e a obrigação moral e ética de tomá-las acessíveis a toda a população (40). 


\subsection{A AIDS em nosso meio}

No Brasil os primeiros casos foram diagnosticados em 1982. Há, contudo, um caso notificado no Estado de São Paulo, com data de diagnóstico de 1980. para o qual foi realizado um estudo retrospectivo. tendo sido o diagnóstico reportado ao ano em que o paciente apresentou quadro clinico compativel com AIDS

Apesar da importância relativa da região Sudeste na epidemia, a AIDS já foi notificada em todos os Estados brasileiros, apresentando, desde seu início até $30 / 06 / 2001,215.810$ casos notificados, $155.456 \mathrm{em}$ homens adultos, $53.040 \mathrm{em}$ mulheres adultas e 7314 em menores de 13 anos de idade (66)

Vale ressaltar que as estatísticas de casos notificados de AIDS em nosso pais são referentes apenas ao número de indivíduos que desenvolveram doença (no Brasil apenas a AIDS é de notificação compulsória), e não ao número de soropositivos para o HIV. O Brasil tem utilizado, até hoje, os resultados dos estudos de clínicas-sentinela e a soroprevalència em populações especificas para estimar o número de HIV positivos existentes no país

A epidemia de AIDS é, hoje, um grande problema de saúde pública no Brasil e, embora, até a atualidade, haja muito mais casos notificados em individuos do sexo masculino, a velocidade de crescimento da epidemia é, como em outros paises, muito maior entre as mulheres do que entre os homens.

No Brasil, a AIDS é uma das principais causas de mortalidade em adultos jovens. No entanto, apesar das condições sócio-econômicas pouco privilegiadas da maioria da população, a mortalidade vem apresentando uma queda acentuada a partir de 1996, sendo o uso de antiretrovirais um dos principais fatores associados a esta diminuição, alem da descentralização do atendimento levando a um diagnóstico mais precoce, com intervenção adequada sobre as infecções oportunistas, o que altera sobremaneira a sobrevida dos pacientes. 


\subsubsection{Perfil da epidemia de A1bS no Estada de São Paulo}

Analisamos os dados obtidos através do Sistema de Vigilância Epidemiológica de DST/AIDS do Estado de São Paulo (ESP), com o intuito de descrever o perfil da epidemia neste Estado e discutir os termos juvenilização, pauperização, heterossexualização e feminização que foram sendo introduzidos no discurso desta epidemia, na tentativa de acompanhar as mudanças de seus padrões epidemiológicos.

O Estado de São Paulo (ESP) tem sido, desde os primórdios da epidemia, responsável por mais de $50 \%$ do total de notificações do pais, senđo o Municipio de São Paulo o que apresenta o maior número absoluto de casos de AIDS no Brasil, como seria de se esperar dada a sua densidade populacional e suas demais caracteristicas de grande centro urbano.

O número de casos de AIDS no Estado de São Paulo com data de diagnóstico e de notificação até 31/12/2001 è de 106.873 casos e destes $44 \%$ (47.047 casos) são residentes no Municipio de São Paulo.

No inicio da epidemia no Estado a imensa maioria dos casos era em homens, e os coeficientes de incidência no sexo masculino eram expressivamente maiores do que no sexo feminino, mas houve um aumento no número de casos em mulheres de tal forma que a relação masculino/feminino que em 1984 era de 27/1 aproxima-se de 2/1 em 1997 e mantém-se neste nivel, apresentando a partir de então ligeira queda ano a ano (tabela 1 e figura 1). Os coeficientes de incidência obedecem a um padrão semelhante ao de número de casos, isto é, aumentam até 1995/1996 para os homens e para o total de casos e até 1998 para a população feminina. 
Tabela 1

Casos notificados de Aids, Coeficiente de Incidência* (CI) por 100.000 habitantes. segundo ano de diagnóstico, sexo e razão de sexo. Estado de São Paulo. 1980-20

\begin{tabular}{|c|c|c|c|c|c|c|c|c|}
\hline \multirow{3}{*}{$\begin{array}{c}\text { Ano de } \\
\text { Diagnóstico }\end{array}$} & \multicolumn{4}{|c|}{ sexo } & \multirow{2}{*}{\multicolumn{2}{|c|}{ total }} & \multirow{3}{*}{$\begin{array}{l}\text { razão } \\
\text { de } \\
\text { sexo }\end{array}$} & \multirow[b]{3}{*}{$\%$} \\
\hline & \multicolumn{2}{|c|}{ masculino } & \multicolumn{2}{|c|}{ feminino } & & & & \\
\hline & casos & $\mathrm{CI}$ & casos & $\mathrm{Cl}$ & casos & CI & & \\
\hline 1980 & 1 & 0,01 & - & - & 1 & 0,00 & - & - \\
\hline 1981 & - & - & - & - & - & - & - & - \\
\hline 1982 & 8 & 0,06 & - & - & 8 & 0,03 & - & - \\
\hline 1983 & 24 & 0,18 & 2 & 0,02 & 26 & 0,10 & $12 / 1$ & 12,00 \\
\hline 1984 & 80 & 0,59 & 3 & 0,02 & 83 & 0,31 & $27 / 1$ & 26,67 \\
\hline 1985 & 326 & 2,36 & 12 & 0,09 & 338 & 1,22 & $27 / 1$ & 27,17 \\
\hline 1986 & 585 & 4,16 & 31 & 0,22 & 616 & 2,18 & $19 / 1$ & 18,87 \\
\hline 1987 & 1363 & 9,50 & 163 & 1,12 & 1526 & 5,28 & $9 / 1$ & 8,36 \\
\hline 1988 & 2164 & 14,78 & 367 & 2,47 & 2531 & 8,57 & $6 / 1$ & 5,90 \\
\hline 1989 & 2929 & 19,62 & 507 & 3,33 & 3436 & 11,40 & $6 / 1$ & 5,78 \\
\hline 1990 & 4224 & 27,73 & 786 & 5,05 & 5010 & 16,28 & $5,5 / 1$ & 5,37 \\
\hline 1991 & 5349 & 34,42 & 1166 & 7,34 & 6515 & 20,72 & $5 / 1$ & 4,59 \\
\hline 1992 & 6455 & 40,84 & 1664 & 10,27 & 8119 & 25,36 & $4 / 1$ & 3,88 \\
\hline 1993 & 6739 & 42,03 & 1914 & 11,61 & 8653 & 26,61 & $3,5 / 1$ & 3,52 \\
\hline 1994 & 6837 & 42,02 & 2098 & 12,51 & 8935 & 27,04 & $3,5 / 1$ & 3,26 \\
\hline 1995 & 7368 & 44,64 & 2613 & 15,32 & 9981 & 29,60 & $3 / 1$ & 2,82 \\
\hline 1996 & 7492 & 44,76 & 3033 & 17,49 & 10525 & 30,89 & $3 / 1$ & 2,47 \\
\hline 1997 & 6912 & 40,52 & 3272 & 18,67 & 10184 & 29,45 & $2 / 1$ & 2,11 \\
\hline 1998 & 7026 & 40,57 & 3589 & 20,15 & 10615 & 30,22 & $2 / 1$ & 1,96 \\
\hline 1999 & 5879 & 33,53 & 3011 & 16,68 & 8890 & 24,98 & $2 / 1$ & 1,95 \\
\hline 2000 & 5002 & 27,66 & 2631 & 14,40 & 7633 & 21,00 & $2 / 1$ & 1,90 \\
\hline 2001 & 2135 & - & 1113 & - & 3248 & - & $2 / 1$ & 1,92 \\
\hline TOTAL & 78.898 & & 27.975 & & 106.873 & & $3 / 1$ & 2,82 \\
\hline
\end{tabular}

Fonte: SINAN- Vigilància Epidemiológica - Programa Estadual DST/Aids-SP

(*) Utilizada projeção populacional da Fundação SEADE

(**) Dados preliminares, sujeitos a revisão mensal, até 31/12/01.

Apesar do aumento do número absoluto de casos até 1996, o ritmo de crescimento diminui gradativamente nos anos 90 , especificamente às custas da população masculina. 
É precoce avaliar o impacto desta diminuição, pois é sabido que há um atraso muito grande nas notificações e conseqüente demora na chegada da informação ao nível central do Sistema de Vigilância Epidemiológica. Sendo assim, o decréscimo percebido nos anos de 1999 e 2000 não pode ainda ser considerado como real, de uma vez que tem havido, ao longo do tempo, inclusão de casos novos em anos muito anteriores à chegada das notificações e isto se observa mais intensamente nos anos mais recentes.

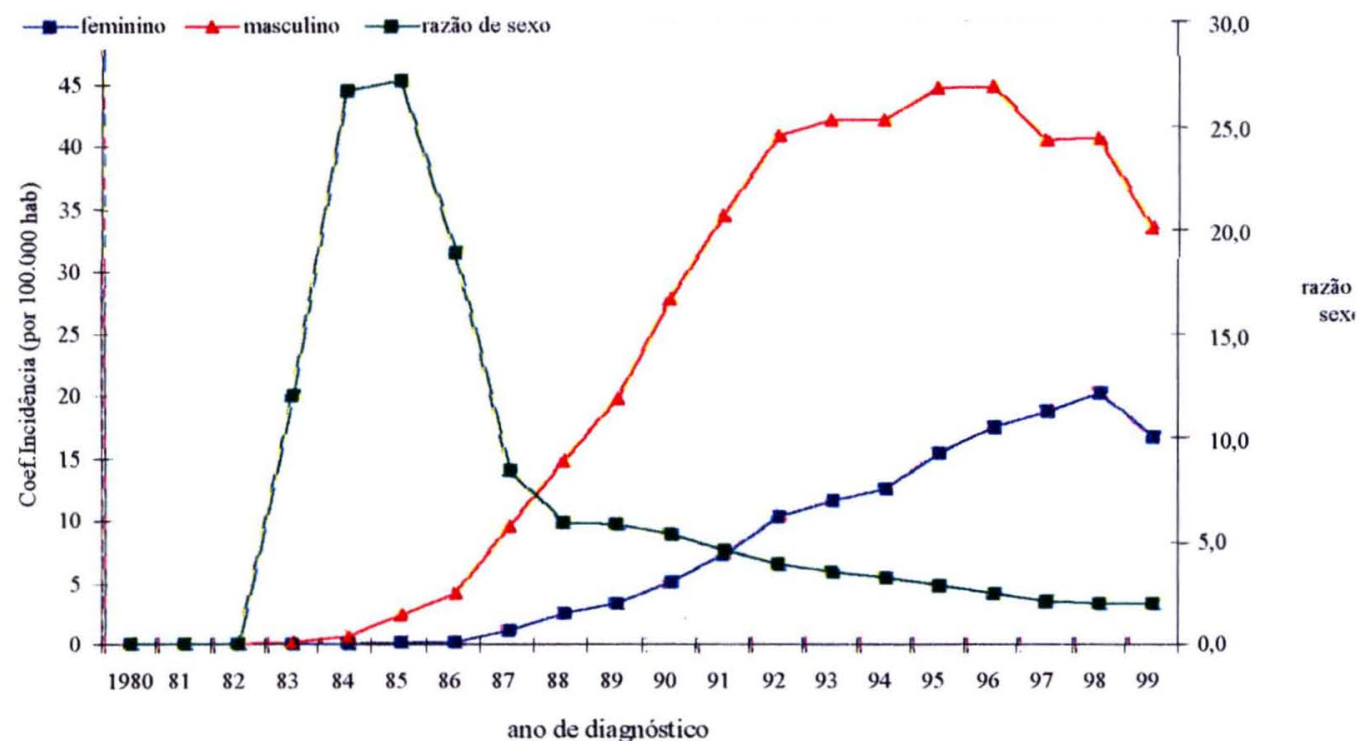

Figura 1. Coeficiente de Incidência de Aids segundo sexo, razão de sexo e ano de diagnóstico, Estado de São Paulo, 1980 a 1999*

Fonte: SINAN -Vigilância Epidemiológica - Programa Estadual

( ${ }^{*}$ dados até $\left.30 / 12 / 01\right)$

A transmissão por via sexual tem sido a mais importante tanto em homens quanto em mulheres, sendo responsável por $50 \%$ do total de casos. Segue a transmissão por via sangüínea, responsável por aproximadamente $30 \%$ dos casos. Dentro da transmissão sangüínea, a via mais importante, em ambos os sexos, é o uso de drogas injetáveis. Pode-se observar nítida queda da transmissão por transfusão sangüínea, em ambos os sexos e em homens hemofilicos depois de 1989, certamente em função da legislação de controle do sangue e hemoderivados que diz respeito à infecção pelo HIV, instituída no Estado de São Paulo em 1986 e no Brasil em 1988 $(57,58)$. 
Há um predominio muito marcado das categorias homossexual e bissexual no início da epidemia e, até 1987 , elas representavam juntas mais de $50 \%$ dos casos masculinos. Nesse ano o uso de drogas injetáveis desponta como uma categoria de transmissão importante para os casos de AIDS e passa a representar cerca de um terço dos casos até meados da década de 1990, quando a proporção da categoria heterossexual aumenta sensivelmente em importância no cenário da epidemia masculina, sendo, atualmente, o uso de drogas injetáveis e a categoria heterossexual, as situações de risco mais prevalentes entre os homens (tabela 2).

Saliente-se que na hierarquização de risco utilizada pela VE de DST/AIDS, a categoria heterossexual só é considerada como forma de transmissão do HIV se o individuo não tiver prática bissexual e não referir nenhum risco de transmissão sanguínea. Mesmo assim imagina-se que este número esteja super estimado, e a importància relativa dos bissexuais na epidemia esteja subestimada, pois no Brasil, a questào da bissexualidade é muitas vezes camuflada por questões morais e culturais, e os individuos tendem a esconder este fato, ressaltando suas relações heterossexuais $(11,74,75)$. $O$ aumento da proporção de individuos heterossexuais pode ser explicado também pelo aumento do número de mulheres infectadas na população.

Quando analisamos a evolução da epidemia no sexo feminino (tabela 3), no ESP, observamos três fases distintas em termos de maior risco para a aquisição da infecção pelo HIV. A primeira fase, até 1986, quando a transmissão pela via sexual era a mais importante, sendo, naquele momento, as parcerias com homens bissexuais e transfundidos as mais freqüentes. Nesse período era importante, também, a transmissão pela transfusão sangüinea. A segunda fase, de 1987 a 1990, quando prevaleceram os casos pelo uso de drogas injetáveis e, a terceira fase, de 1991 ate o presente, quando a prática heterossexual voltou a ser a principal situação de risco descrita entre os casos de AIDS em mulheres, sendo agora a parceria sexual com homens usuários de drogas injetáveis a mais relevante (Tabela 3 ).

Temos, ainda, notificado um caso feminino, que é o primeiro caso confirmado de AIDS por acidente profissional no Brasil. 
$|\wedge B| 1 \wedge 2$

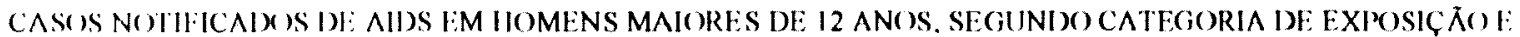

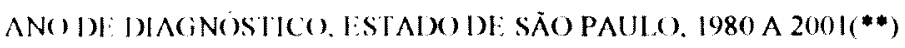

\begin{tabular}{|c|c|c|c|c|c|c|c|c|c|c|c|c|c|c|c|c|c|c|c|c|}
\hline \multirow{3}{*}{$\begin{array}{c}\text { Amo } \\
\text { de } \\
\text { Dagmintico }\end{array}$} & \multicolumn{18}{|c|}{ Calcgoria de Exposiçáo } & \multirow{2}{*}{\multicolumn{2}{|c|}{ TOTAL. }} \\
\hline & \multicolumn{2}{|c|}{11() $\mathrm{MO})$} & \multicolumn{2}{|c|}{131} & \multicolumn{2}{|c|}{ HIIII:RO } & \multicolumn{2}{|c|}{ III)I } & \multicolumn{2}{|c|}{$\left.|\|S\| \div| U D\right|^{*}$} & \multicolumn{4}{|c|}{ HIEMOFII T.SANGUE(\& } & \multicolumn{2}{|c|}{ INVI:SI. } & \multicolumn{2}{|c|}{$\longdiv { M \wedge T I N I }$} & & \\
\hline & No. & "0 & No. & $" 0$ & No. & $\circ$ & No. & $\therefore$ & No. & $0_{0}$ & No. & $0_{0}$ & No. & ${ }^{0} 0$ & No. & ${ }^{\circ}{ }_{0}$ & No. & $0_{0}^{\circ}$ & No. & $0_{0}$ \\
\hline 1980 & - & - & 1 & 100.0 & - & - & - & - & - & - & . & - & - & - & - & - & - & - & 1 & . \\
\hline 1981 & - & - & - & - & - & - & - & . & - & - & - & - & - & - & - & - & - & - & - & - \\
\hline 1082 & 2 & 25.0 & 3 & 37.5 & 1 & 12.5 & . & - & 2 & 250 & - & - & . & . & - & . & - & . & 8 & - \\
\hline 1983 & 12 & 52.2 & 7 & 30.4 & - & - & 1 & 4.3 & . & - & - & - & - & - & 3 & 13.0 & - & - & 23 & 100.0 \\
\hline 1084 & 4.4 & 56.4 & 16 & 20.5 & 1 & 1.3 & 6 & 7.7 & 4 & 5.1 & 1 & 1.3 & - & - & 6 & 7,7 & - & - & 78 & 100.0 \\
\hline 1985 & 162 & 50.9 & 80 & 25.2 & 12 & 3.8 & 10 & 3.1 & 19 & 6.0 & 4 & 1.3 & 2 & 0.6 & 29 & 9.1 & - & - & 318 & 100,0 \\
\hline 1980 & 303 & 53,3 & 106 & 18.6 & 28 & 4.9 & 47 & 8.3 & 36 & 6,3 & 10 & 1.8 & 3 & 0,5 & 36 & 6.3 & - & . & 569 & 100.0 \\
\hline 1987 & 555 & 42.3 & 192 & 14.6 & 89 & 6.8 & 208 & 15.9 & 106 & 8.1 & 24 & 1,8 & 11 & 0,8 & 127 & 9.7 & - & - & 1312 & 100.0 \\
\hline 1988 & 753 & 35.7 & 282 & 13.4 & 157 & 7,4 & 511 & 24.2 & 139 & 6.6 & 37 & 1.8 & 15 & 0.7 & 216 & 10.2 & - & - & 2110 & 100,0 \\
\hline 1989 & 857 & 29.9 & 342 & 11.9 & 293 & 10.2 & 834 & 29.1 & 228 & 8.0 & 27 & 0.9 & 21 & 0.7 & 263 & 9.2 & - & . & 2865 & 100.0 \\
\hline 1990 & 10.49 & 25.5 & 396 & 9.6 & +32 & 10.5 & 1384 & 33.7 & 316 & 7.7 & 39 & 0.9 & 20 & 0.5 & 475 & 11.6 & - & - & 4111 & 100.0 \\
\hline 1991 & 1173 & 22.4 & 472 & 9,0 & 673 & 12,9 & 1862 & 35.6 & 412 & 7.9 & .37 & 0.7 & 29 & 0.6 & 57.4 & 11,0 & - & . & 5232 & 100.0 \\
\hline 1992 & 1283 & 20.3 & 567 & 9.0 & 957 & 15.2 & 2193 & 34.8 & 443 & 7.0 & 31 & 0.5 & 29 & 0.5 & 804 & 12.7 & - & - & 6307 & 100.0 \\
\hline$\{99\}$ & 1143 & 17.4 & 484 & 7.4 & 1191 & 18.1 & 2296 & 34.9 & 382 & 5.8 & 27 & 0.4 & 22 & 0.3 & 1036 & 15.7 & - & - & 6581 & 100.0 \\
\hline$|(9)|$ & 1102 & 16.5 & $4(10)$ & 7.0 & 1296 & 19.4 & 2119 & 31.8 & .357 & 5.4 & .30 & 0.4 & 18 & 0.3 & 1280 & 19.2 & - & - & 6671 & 100.0 \\
\hline 1045 & 11132 & 141 & $|x|$ & 6.7 & 1.390 & 19.4 & 2095 & 29.2 & 377 & 5.2 & 28 & 0.4 & 30 & 0.4 & 1748 & 24,3 & - & - & 7181 & 100,0 \\
\hline foves & 1129 & 15.5 & 411 & 6.0 & 1651 & 22.6 & 2017 & 27.6 & 32.4 & 4.4 & 25 & 0.3 & 24 & 0.3 & 1687 & 23.1 & - & - & 7298 & 100.0 \\
\hline $19 y 7$ & 1126 & 16.8 & 5.3 .3 & 7.9 & 1720 & 25.6 & 1776 & 26.4 & 350 & 5.2 & 34 & 0.5 & 7 & 0.1 & 1175 & 17.5 & - & - & 6721 & 100.0 \\
\hline $\mid(1) \times$ & 1071 & 15.5 & $5 \times 4$ & 8.5 & 1756 & 25.5 & 1.461 & 21,2 & 388 & 5.6 & 13 & 0.2 & 1 & - & 1622 & 23.5 & - & . & 6896 & 100,0 \\
\hline $\mid 0(y)$ & 861 & 15.0 & 509 & 8.8 & 1565 & 27.2 & 1138 & 19.8 & 280 & 4.9 & 8 & 0.1 & - & - & 1391 & 24.2 & 1 & 0.0 & 5753 & 100.0 \\
\hline 2000 & 748 & 15.3 & 420 & 8.6 & 1370 & 28.0 & 922 & 18.8 & 245 & 5.0 & 5 & - & - & - & 1187 & 24.2 & 2 & 0.0 & 4899 & 100.0 \\
\hline 20011 & 304 & 14.7 & 194 & 9.2 & $6+1$ & 30.5 & 356 & 16.9 & 76 & 3.6 & 2 & - & - & - & 526 & 25.0 & - & - & 2104 & 100.0 \\
\hline
\end{tabular}

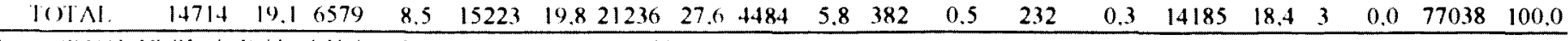

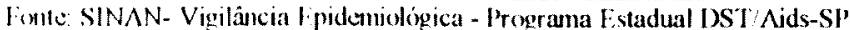

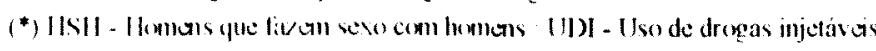

(**) Dador préliminares. sujecilos al revisào mutsal, até 31:1201.

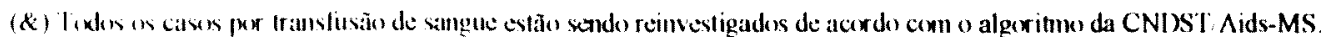


TABBIA:

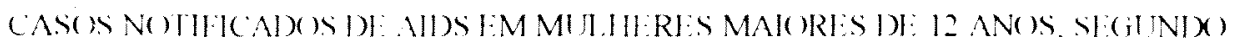

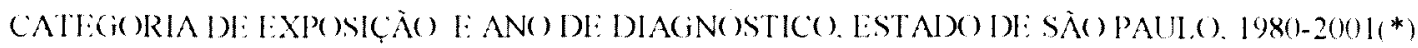

\begin{tabular}{|c|c|c|c|c|c|c|c|c|c|c|c|c|}
\hline \multirow{3}{*}{$\begin{array}{c}\text { ANODH: } \\
\text { DIAGNOSTICO }\end{array}$} & \multicolumn{10}{|c|}{ CATEOCORIADE EXPOSIÇAO } & & \\
\hline & \multicolumn{2}{|c|}{ HI:TH:RO } & \multicolumn{2}{|c|}{ IDI } & \multicolumn{2}{|c|}{ T.SANCIUI: \& } & \multicolumn{2}{|c|}{ MATINT: } & \multicolumn{2}{|c|}{ INVEST } & \multicolumn{2}{|c|}{ TOTAL } \\
\hline & No. & $0 \%$ & No. & $\%$ & No. & $\%$ & No. & $\%$ & No. & $\%$ & No. & $\%$ \\
\hline 1980 & - & - & - & - & - & - & $\cdot$ & - & - & - & - & - \\
\hline 1981 & - & - & - & - & - & - & - & - & - & - & - & - \\
\hline 1982 & - & - & - & - & - & - & $\cdot$ & - & - & - & - & - \\
\hline 198.3 & 1 & 50.0 & 1 & 50.0 & - & - & - & - & - & - & 2 & 100.0 \\
\hline 1984 & 1 & - & - & - & - & - & - & - & 2 & 66.7 & 3 & 100,0 \\
\hline 1985 & 6 & 54.5 & 1 & - & 1 & 9.1 & - & - & 3 & 27.3 & 11 & 100.0 \\
\hline 1986 & 13 & 46.4 & 8 & 28.6 & 2 & 7.1 & - & - & 5 & 17.9 & 28 & 100,0 \\
\hline 1987 & 45 & 30.4 & 82 & 55.4 & 6 & 4.1 & - & - & 15 & 10.1 & 148 & 100,0 \\
\hline 1988 & 105 & 33.7 & 158 & 50,6 & 11 & 3.5 & - & - & 38 & 12.2 & 312 & 100,0 \\
\hline 1989 & 164 & 36.8 & 217 & 48.7 & 15 & 3.4 & - & - & 50 & 11.2 & 446 & 100.0 \\
\hline 1990 & 309 & 43.5 & 318 & 44.7 & 14 & 2,0 & - & - & 70 & 9.8 & 711 & 100,0 \\
\hline 1991 & 483 & 45.7 & 404 & 38,2 & 24 & 2.3 & - & - & 146 & 13.8 & 1057 & 100.0 \\
\hline 1992 & 823 & 53.5 & 526 & 34.2 & 25 & 1.6 & - & - & 164 & 10.7 & 1538 & 100.0 \\
\hline 1993 & 1027 & 57.7 & +90 & 27.5 & 20 & 1.1 & - & - & 244 & 13.7 & 1781 & 100.0 \\
\hline 1994 & 1218 & 62.2 & 436 & 22,3 & 13 & 0,7 & - & - & 290 & 14.8 & 1957 & 100,0 \\
\hline 1995 & 1480 & 61.4 & 413 & 17,1 & 20 & 0,8 & - & - & 498 & 20,7 & 2411 & 100,0 \\
\hline 1996 & 1810 & 63,9 & 469 & 16,6 & 18 & 0,6 & - & - & 534 & 18.9 & 2832 & 100,0 \\
\hline 1997 & 2168 & 70.1 & 428 & 13.8 & 5 & 0.2 & 1 & - & 489 & 15.8 & 3091 & 100.0 \\
\hline 1998 & 2253 & 65.2 & 390 & 11,3 & 2 & 0,1 & 1 & 0,0 & 807 & 23.4 & 3453 & 100,0 \\
\hline 1999 & 1896 & 65.9 & 277 & 9,6 & - & - & - & - & 703 & 24.4 & 2876 & 100,0 \\
\hline 2000 & 1629 & 64,2 & 192 & 7,6 & 1 & - & - & - & 717 & 28,2 & 2539 & 100,0 \\
\hline 2001 & 721 & 66.6 & 81 & 7.5 & - & - & 1 & 0.1 & 280 & 25,9 & 1083 & 100.0 \\
\hline TOTAL & 16152 & 61.5 & 4891 & 18.6 & 177 & 0.7 & 3 & 0.0 & 5055 & 19.2 & 26279 & 100,0 \\
\hline
\end{tabular}

Fonte: SINAN- Vigilancia Epidemologica - Programa Estadual DST/Aids-SP

(**) Dados preliminares. sujeitos a revisão mensal. até 31/12/01.

For contirmado um caso de exposiçao por acidente protissional em 1996

(\&) Todos os casos por transtusão de sangue estão sendo reinvestigados de acordo com o algoritmo da CNDST/Aids-MS.

Em trabalho realizado com 2759 mulheres notificadas no ESP com diagnóstico até julho/1992, 34,6\% das mulheres, que referiram como situação de risco principal a prática sexual, eram parceiras de homens UDI (85). Pelos dados obtidos através da Vigilància Epidemiológica de DST/AIDS do Estado de São Paulo, entre todas as mulheres notificadas com AIDS no Estado, com categoria de exposição heterossexual, do inicio da epidemia ate $1997,40,1 \%$ referiram parceria sexual com UDI. Em dezembro de 2001 a proporção de mulheres heterossexuais com parceiros usuários de drogas desde o inicio da epidemia foi de $31,7 \%$ 
Na tabela 4 e Figura 2 podemos observar a proporçào do tipo de parcerias entre o total de casos notificados em homens e mulheres com categoria de exposição heterossexual. Note-se que a multiplicidade de parceiros é relatada muito mais frequentemente pelos homens, e que a parceria com usuarios de drogas injetáveis é do tipo mais frequente entre as mulheres, seguida pela multiplicidade de parceiros.

\begin{tabular}{|c|c|c|c|c|}
\hline \multirow{4}{*}{ Tipo de Parceria } & \multirow{2}{*}{\multicolumn{3}{|c|}{ Sexo }} & \\
\hline & & & & \\
\hline & \multicolumn{2}{|c|}{ Masculino } & Feminino & \\
\hline & No. & $\%$ & No. & $\%$ \\
\hline Múltipla parceria & 9933 & 65,10 & 3924 & 24,30 \\
\hline Parceiro UDI & 950 & 6,20 & 5120 & 31,70 \\
\hline Parc. Múltiplos Parceiro & 1025 & 6,70 & 2259 & 14,00 \\
\hline Parc. Transfundido & 184 & 1,20 & 201 & 1,20 \\
\hline Parc.Hemofilico & - & - & 73 & 0,50 \\
\hline Parc. Bissexual & - & - & 1137 & 7,00 \\
\hline Outras parcerias & 3131 & 20,80 & 3438 & 21,30 \\
\hline Total & 15223 & 100,00 & 16152 & 100,00 \\
\hline
\end{tabular}

Estes dados reiteram a observação de que o uso de drogas injetáveis se constituiu em um importante fator de disseminação da epidemia de AIDS em nosso meio, particularmente para a população feminina, quer pela transmissão sangüinea entre os usuários de drogas injetáveis, quer pela parceria sexual com os mesmos.

Atualmente, tomando-se o total de casos femininos desde 1983, temos que a maioria das mulheres se contaminou pelas relações heterossexuais, sendo o uso de drogas injetáveis, a segunda categoria de transmissão mais prevalente entre os casos femininos notificados. 

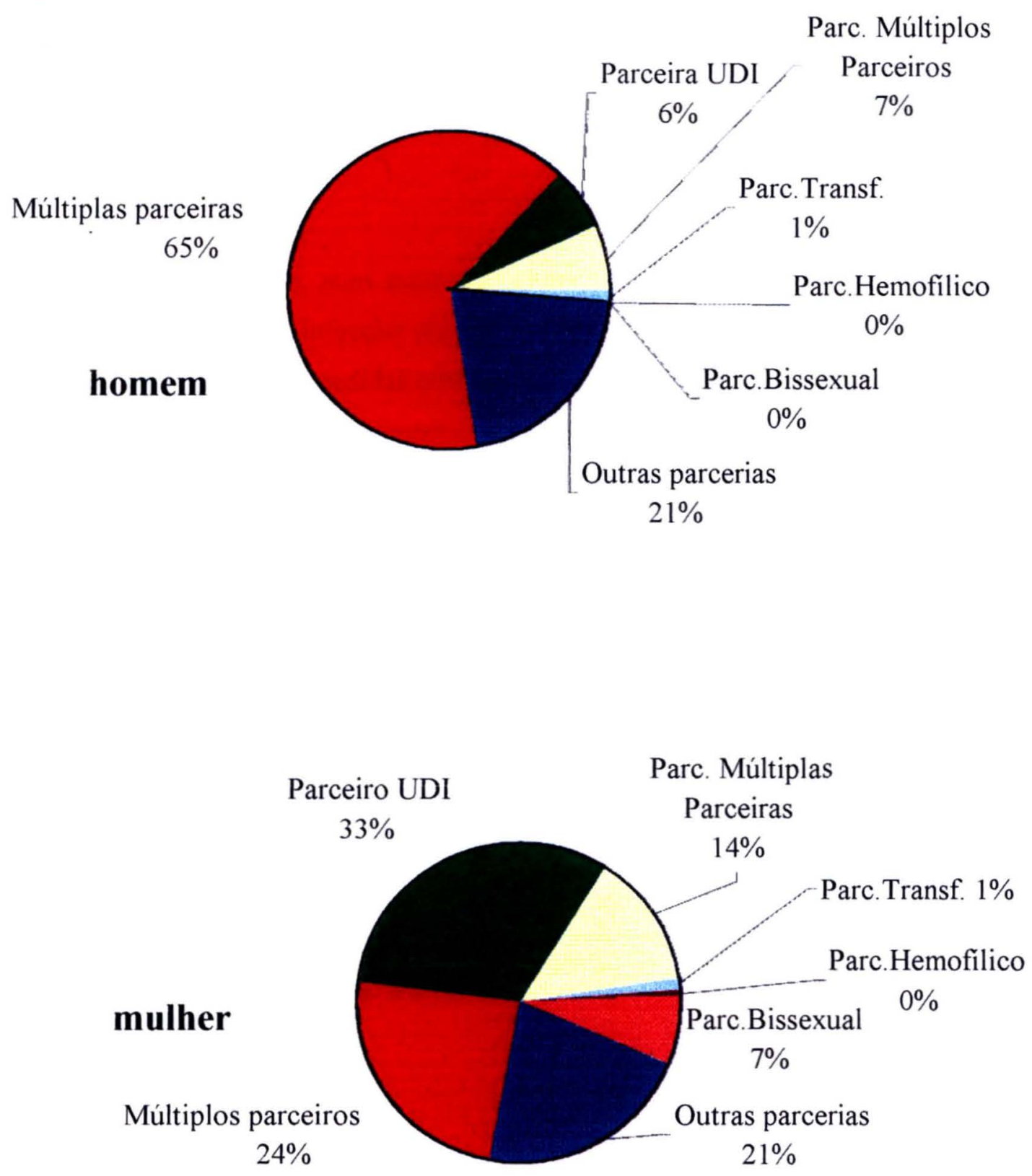

Figura 2. Casos notificados de Aids, em indivíduos com categoria de transmissão heterossexual, segundo parceria sexual e sexo, Estado de São Paulo, 1980 a 2001* Fonte: Vigilância Epidemiológica - Programa Estadual DST/Aids ( ${ }^{*}$ dados até 30/12/01) 
$\mathrm{O}$ aumento do número de casos em mulheres traz, como consequência. um maior numero de casos em crianças pela transmissão materno-infantil. Esta forma de transmissào é responsavel por mais de $80 \%$ dos casos notificados em menores de 13 anos de idade (Tabela 5)

Ressalte-se que, num momento anterior, já tivemos um resultado bastante satisfatório na redução da infecção pelo HIV através das transfusões sangüineas e de hemoderivados, através das medidas então preconizadas para o controle da qualidade do sangue transfundido, e, analogamente, a transmissào materno-infantil pode ser drasticamente reduzida desde que a gestante e seu concepto tenham o diagnóstico da infecção pelo HIV realizado a tempo de instituir as medidas profiláticas hoje disponiveis.

Embora em número muito pequeno, aparecem casos de AIDS em menores de 13 anos devidos à transmissão sexual (3 casos) e ao uso de drogas injetáveis (6 casos), ainda que estes casos não tenham impacto em relação ao total da epidemia, têm uma importância social muito grande, pois denotam a falta de proteção a que muitas crianças estão expostas na nossa sociedade. Os demais casos são conseqüentes à contaminação pela transfusão sangüinea e de hemoderivados que, como para os adultos, vêm diminuindo rapidamente ano a ano. 
I.1B11.AS

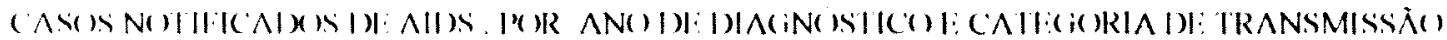

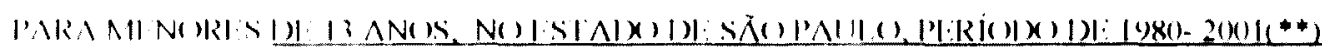

\begin{tabular}{|c|c|c|c|c|c|c|c|c|c|c|c|c|c|c|c|c|c|c|}
\hline \multirow{3}{*}{ 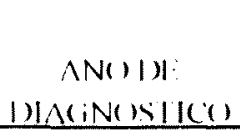 } & \multicolumn{16}{|c|}{ 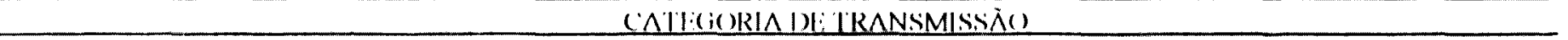 } & & \\
\hline & \multicolumn{2}{|l|}{$116 \mathrm{MC})$} & \multicolumn{2}{|c|}{ III:II:R() } & \multicolumn{2}{|c|}{$\mid 11) \mid$} & \multicolumn{2}{|c|}{$\|s\|+\|\|) \mid$} & \multicolumn{2}{|c|}{ HIM( $)$} & \multicolumn{2}{|c|}{ I SAN(iUlE(\&) } & \multicolumn{2}{|c|}{ MAII:RNCLINI: } & \multicolumn{2}{|c|}{ INVI:ST } & \multicolumn{2}{|c|}{ U() } \\
\hline & No. & $11 / 0$ & No. & $\%$ & No. & $\%$ & No. & $\%$ & No. & $\%$ & No. & $\%$ & No. & $\%$ & No. & $\%$ & No & $\%$ \\
\hline $14 x \cdot 4$ & - & - & - & - & - & - & - & - & 1 & 100.0 & - & 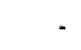 & - & - & - & - & 1 & 100.0 \\
\hline 85 & - & - & - & $\cdot$ & - & - & - & - & 3 & 75.0 & 1 & 25.0 & - & - & - & - & 4 & $I(1)(0)$ \\
\hline$x$, & . & - & - & - & - & - & - & . & 6 & 50,0 & 5 & 41.7 & - & - & 1 & 8,3 & 12 & 10101.0 \\
\hline 87 & - & . & - & - & - & - & - & - & 15 & 27.3 & 10 & 18.2 & 26 & 47.3 & 4 & 7.3 & 55 & $1(00.0)$ \\
\hline $8 x$ & 1 & 111 & - & . & 2 & 2.0 & . & - & 5 & 5.0 & 17 & 17.0 & 69 & 69.0 & 6 & 0,0 & 100 & $1(10), 0$ \\
\hline x' & - & - & - & . & 2 & 1,7 & - & - & 10 & 8,3 & 14 & 11.7 & 85 & 70,8 & 9 & 7.5 & 120 & 100.0 \\
\hline 91 & 1 & 0.6 & - & - & 1 & 0.6 & - & - & 15 & 8.9 & 11 & 6.5 & 128 & 76.2 & 12 & 7.1 & 16.8 & 100.0 \\
\hline 1) & - & . & 1 & 0,3 & - & - & - & - & 4 & 1.9 & 10 & 4.7 & 184 & 80,8 & 13 & 6.1 & 212 & {$[00.0$} \\
\hline 92 & - & . & - & . & - & - & . & - & 5 & 2.0 & 17 & 6.8 & 214 & 85.6 & 14 & 5,6 & 250 & 100,01 \\
\hline 93 & . & . & - & - & 1 & 0.4 & 1 & 0.4 & 3 & 1.1 & 11 & 4.1 & 230 & 85,8 & 23 & 8.6 & 26.8 & $\mid(x), 0$ \\
\hline 9.4 & $\cdot$ & . & - & . & . & - & - & . & 2 & 0.7 & 8 & 2.7 & 259 & 88.1 & 25 & 8.5 & 29.4 & $\mid(x), 0)$ \\
\hline 95 & . & . & - & . & - & - & - & - & 2 & 0,6 & 12 & 3,3 & 307 & 85.5 & 38 & 10.6 & 359 & $\ln (x), 0$ \\
\hline$x^{\prime}$ & . & - & - & - & - & - & - & - & 1 & 0.3 & 3 & 0.8 & 335 & 86.3 & 49 & 12,6 & 388 & 100.0 \\
\hline 97 & . & . & - & - & - & - & . & - & - & - & 1 & 0,3 & 342 & 93.4 & 23 & 6,3 & 360 & $1(0), 0$ \\
\hline xי & - & - & - & . & - & - & - & - & - & - & 1 & 0,4 & 215 & 83.0 & 43 & 16,6 & 259 & 100,0 \\
\hline (y) & - & . & - & . & - & - & - & - & 1 &. & 1 & . & 227 & 87.3 & 31 & 11.9 & 260 & 100,01 \\
\hline $2(x) 10$ & - & . & - & . & - & - & - & - & - & . & 2 & . & 165 & 84.6 & 28 & 14.4 & 195 & $I(K) .(1)$ \\
\hline $2 \times n 1$ & - & - & - & . & - & - & - & - & - & - & 2 & . & 53 & 80.9 & 6 & 9.8 & 61 & 100,11 \\
\hline $111 \times 1$ & 2 & (1). & 1 & 0,0 & $\theta$ & 0.2 & 1 & 0,0 & 73 & 22 & 126 & 3.7 & 2839 & 84,2 & 325 & 96 & 3372 & $1(0) 0$ \\
\hline
\end{tabular}

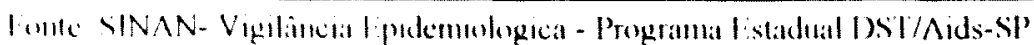

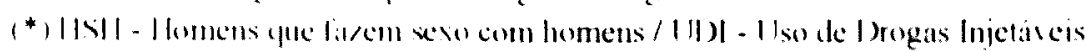

(**) ladus prelimmares, sujeites a revisio mensal. ate $31 / 12 / 01$

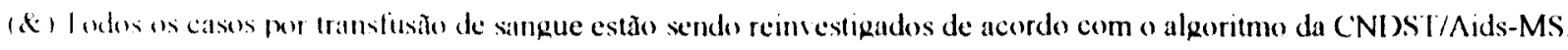




\subsection{1.a. A mortalidade por AIDS}

O pico de mortalidade por AIDS, em nosso Estado. ocorreu em 1995, ano em que ocorreram 7739 óbitos por AIDS no Estado. com uma taxa de mortalidade de 22.89 por $100.000 \mathrm{hab}$

A queda da mortalidade na população masculina aconteceu anteriormente à feminina. além de ocorrer em maior proporção entre os homens do que entre as mulheres, mas a velocidade de decréscimo dos obitos diminuiu muito nos dois últimos anos, e nas mulheres, particularmente. embora mantendo uma taxa de mortalidade praticamente constante, houve, no Estado de São Paulo, um pequeno acréscimo no número absoluto de óbitos registrados em 2000 (1241) com relação a 1999 (1200). Segundo dados do Programa de Aprimoramento das Informações de Mortalidade do Municipio de São Paulo - PRO-AIM, também em 2001, o numero absoluto de óbitos por AIDS em mulheres, no Municipio de São Paulo, foi um pouco maior com relação ao ano 2000,398 e 382 , respectivamente

Assim, como no número de casos, o declínio da relação masculino/feminino dos óbitos por AIDS tem demonstrado o avanço da epidemia entre as mulheres

$\mathrm{Na}$ tabela 6 podemos observar o número de óbitos por AIDS notificados ao Sistema de Vigilància por ano de ocorrência e por outras fontes de informação - o Sistema de Informações sobre Mortalidade (SIM) e o Sistema de Mortalidade por Aids - SAIDS, produzido pela Fundação Sistema Estadual de Análise de Dados SEADE, instituição responsável, no Estado de São Paulo, pela produção das estatisticas de óbitos e de nascimentos.

Comparando-se os óbitos por ano de ocorrência dos sistemas de informação há uma discrepància entre eles. Os números do sistema de VE são expressivamente maiores do que os do SIM ate 1990, e são bem menores do que os do SEADE a partir de 1991, com exceção de 1995 e 1998, anos em que o serviço de VE fez um trabalho de resgate manual dos óbitos de AIDS de todo o Estado, através das Declarações de Óbito (DO) fornecidas pela Fundação SEADE. 
TABELA 6

OBITOS DE AIDS. COEFICIENTE DE MORTALIDADE* (CM) POR $100,0(1)$ HABITANTES. SEGUNDO ANO DE DIAGNÓSTICO. ESTADO DE SÃO PAULO. 1980 A $2000(* *)$

\begin{tabular}{|c|c|c|c|c|}
\hline $\begin{array}{c}\text { ANODE } \\
\text { DIAGNOSTICO }\end{array}$ & $\begin{array}{c}\text { OBITOS* } \\
\text { (SIM/SEADE) }\end{array}$ & $\mathrm{CM}$ & $\begin{array}{l}\text { OBITOS } \\
\text { (SINAN) }\end{array}$ & $\mathrm{CM}$ \\
\hline 1980 & 1 & - & . & - \\
\hline 1981 & - & - & 1 & - \\
\hline 1982 & () & 0.00 & 2 & 0.01 \\
\hline 1983 & 1 & 0.00 & 16 & 0.06 \\
\hline 1984 & 0 & 0.00 & 50 & 0.18 \\
\hline 1985 & 74 & 0.27 & 173 & 0.62 \\
\hline 1986 & 198 & 0.70 & 297 & 1.05 \\
\hline 1987 & +37 & 1.51 & 705 & 2.44 \\
\hline 1988 & 1075 & 3.64 & 1379 & +.67 \\
\hline 1989 & 1665 & 5.52 & 2188 & 7.26 \\
\hline 1990 & 3098 & 10.06 & 3179 & 10.33 \\
\hline 1991 & +218 & 13.42 & +103 & 13.05 \\
\hline 1992 & 5021 & 15.68 & 4761 & 14.87 \\
\hline 1993 & $6+33$ & 19.78 & 5676 & 17.45 \\
\hline 1994 & 7091 & 21.46 & 6273 & 18.98 \\
\hline 1995 & 7739 & 22.95 & 7528 & 22.33 \\
\hline 1996 & 7269 & 21.33 & 6763 & 19.85 \\
\hline 1997 & 5536 & 16.01 & $+2+2$ & 12.27 \\
\hline 1998 & +591 & 13.07 & $+6+7$ & 13.23 \\
\hline 1999 & +257 & 11.96 & 3562 & 10.01 \\
\hline 2000 & +181 & - & 3568 & - \\
\hline TOTAL & 59434 & & 59113 & \\
\hline
\end{tabular}

Fonte: SINAN- Vigilància Epidemiológica - Programa Estadual DST/Aids-SP

*óbitos: SIM-DATASUS (1980 a 1989) e SEADE (1990 a 2000)

(**) Dados preliminares. sujeitos a revisão mensal até $31 / 12 / 01$

(***) Utilizada projeção populacional da Fundação SEADE.

não incluidos 9 óbitos sem data

Uma possivel explicação para isto é que no início da epidemia, por questões sociais e pseudo éticas, os medicos tivessem maior resistència para colocar o diagnóstico de AIDS na Declaração de Óbito (DO) e diversos casos evoluiram para óbito por AIDS, sem que isto constasse da DO (19) passando despercebidos pelos sistemas de informação, sendo provável que, num período inicial da epidemia, fosse mais freqüente o registro dos óbitos de pacientes já notificados A partir de 1991, com o grande número de óbitos ocorridos e a banalização do diagnóstico, mais casos foram sendo relatados oficialmente nas DO e, antagonicamente, esta mesma banalização talvez tenha levado a uma diminuição da sensibilidade dos profissionais para a notificação dos casos de AIDS, aumentando, portanto, o número de cusos 
conhecidos apenas atraves do sistema de mortalidade. Alem disto. desde 1990. o PRO-AIM e a Fundaçào SEADE tem trabalhado com as DO suspeitas de AIDS e encaminhado para investigạção

Comparando os coeficientes de mortalidade por sexo (tabela 7) vè-se que o pico da monalidade ocorreu em 1994/1995 para os homens e 1995/1996 para as mulheres. declinando, depois, mais intensamente na população masculina do que na feminina. A razão masculino/feminino dos óbitos é semelhante à dos casos, atinge seu pico em $1986(38.6 / 1)$ e diminui gradativamente até chegar a 2.36 no ano 2000.

TABILLA 7:

COEFICIFNTF DF MORTAIIDADE POR AIDS (POR 100.000 HABITANTES) E RAZÃO PROPORCIONAI DE OBITOS MASCULINOS E FEMININOS. SEGUNDO SEXO E ANO DE OCORRENCIA. ISTADO DE SÃO PAULO. 1980 A $2000\left({ }^{* *}\right)$

\begin{tabular}{|c|c|c|c|c|c|}
\hline \multirow{4}{*}{$\begin{array}{l}\text { ANODE } \\
\text { OBITO }\end{array}$} & \multicolumn{4}{|c|}{ Sexo } & \multirow{4}{*}{$\begin{array}{c}\text { RALÃO } \\
\text { OB. MF } \\
\text { SIM/SEADE* }\end{array}$} \\
\hline & \multicolumn{2}{|c|}{ Masculino } & \multicolumn{2}{|c|}{ Feminino } & \\
\hline & $\mathrm{CM}$ & & $\mathrm{CM}$ & & \\
\hline & SIM/SE AIDE* & V.E & SIM/SEADE* & V.E. & \\
\hline 1980 & - & - & $\cdot$ & - & - \\
\hline 1981 & - & 0.01 & - & - & - \\
\hline 1982 & - & 0.02 & - & - & - \\
\hline 1983 & 0.01 & 0.12 & - & - & - \\
\hline 1984 & - & 0.37 & - & - & - \\
\hline 1985 & 0.51 & 1.23 & 0,03 & 0.03 & 17.5 \\
\hline 1986 & 1.37 & 2.05 & 0.04 & 0.06 & 38.6 \\
\hline 1987 & 2.83 & 4.46 & 0.21 & 0.45 & 13.10 \\
\hline 1988 & 6.41 & 8.23 & 0.92 & 1.18 & 6.85 \\
\hline 1989 & 9.58 & 12.77 & 1.54 & 1.85 & 6.12 \\
\hline 1990 & 17.30 & 18.03 & 2.97 & 2.78 & 5.73 \\
\hline 1991 & 22.50 & 22.00 & 4.54 & 4.30 & 4.82 \\
\hline 1992 & 26.02 & 24.94 & 5.60 & 5.05 & 4.54 \\
\hline 1993 & 32.20 & 28.59 & 7.70 & 6.62 & 4.10 \\
\hline 1994 & 34.45 & 30.66 & 8.85 & 7.66 & 3.77 \\
\hline 1995 & 35.44 & 34.60 & 11.08 & 10.66 & 3.09 \\
\hline 1996 & 32.09 & 29.92 & 10.95 & 10.12 & 2.83 \\
\hline 1997 & 23.35 & 17.69 & 8,86 & 6.98 & 2.56 \\
\hline 1998 & 18.80 & 19.10 & 7.50 & 7.52 & 2.43 \\
\hline 1999 & 17.44 & 14.70 & 6.65 & 5.45 & 2.55 \\
\hline 2000 & 16.26 & 13.82 & 6.59 & 5.86 & 2.36 \\
\hline
\end{tabular}

Fonte: SINAN- Vigilância Epidemiológica - Programa Estadual DST/Aids-SP

*óbitos: SIM-DATASUS (1980 a 1989) e SEADE (1990 a 2000)

$\left({ }^{* *}\right)$ Dados preliminares. sujeitos a revisão mensal. até $31 / 12 / 01$.

$(* * *)$ Utilizada projeçào populacional da Fundação SEADE. 
Na faixa etaria do adulto jovem. segundo os dados do PRO-AIM e da Fundação SEADE. a AIDS figura entre as principais causas de mortalidade tanto no Municipio quanto no Estado de São Paulo, tendo sido a principal causa de mortalidade das mulheres em idade fértil de 1991 a 1998 . Em 1999 e 2000. a AIDS foi a segunda causa de morte para as mulheres entre 15 e 49 anos. no ESP, tendo surgido. como primeira causa. as Doenças Cerebro-Vasculares. Para os homens, A AIDS oscila. de 1991 ate o ano 2000, entre a segunda e a terceira causa, estando. para estes, em primeiro lugar os homicidios e os acidentes de trânsito. No ano de 1998 a AIDS foi a oitava causa de morte, em todas as idades no ESP, sendo a sexta para os homens e a décima para as mulheres

O comportamento apresentado pela mortalidade por Aids, segundo a idade, é diferente nas populaçòes masculina e feminina. Entre 1988 e 1997 o pico de idade para a mortalidade por AIDS foi entre 30-34 anos na população masculina e, para as mulheres, entre 25-29 anos (100).

Analisando a mortalidade por AIDS no Estado de São Paulo, de 1990 até o ano 2000, WALDVOGEL (2002) coloca : "Para os homens, observa-se uma redução nas taxas de mortalidade por Aids na população com ate 30 anos de idade, quando se comparam os dados de 1990 e 2000. A partir deste corte etário, as taxas aproximamse bastante .... O que difere em relação às mulheres é que para esta parcela da população a desaceleração da incidència e da mortalidade por Aids foi menor, de forma que a curva descrita pelas taxas de mortalidade por idade, em 2000, ainda não está proxima da correspondente a 1990. Note-se, também, para as mulheres, que houve uma defasagem nas idades mais atingidas pela Aids: em 1990 a faixa etária mais afetada situa-se entre 20 e 29 anos; em 2000, ela corresponde às idades entre 30 e 39 anos. semelhante ao padrão verificado na população masculina.

Por outro lado, os homens com mais de 35 anos registram um padrão distinto do descrito até o momento. Os casos fatais de Aids, observados em tal parcela da população, apresentam très movimentos: um primeiro aumento até atingir um máximo na metade da década. uma diminuição até 1998/1999 e um novo aumento entre 1999/2000 
As mulheres entre 20 e 29 anos tambem foram as primeiras a reverter a tendencia crescente dos casos fatais de Aids. O grupo etario entre 30 e 34 anos apresentou queda importante a partir de 1996/97, mas permanece no mesmo patamar nos dois ultimos anos considerados. As mulheres com mais de 35 anos registram padrão semelhante ao verificado pelos homens desta idade. com très movimentos na curva descrita pelos casos fatais de Aids." (101)

Apesar do quadro otimista com relação à evolução da mortalidade da AIDS em São Paulo, a diminuição da velocidade da queda dos obitos e o pequeno aumento no numero absoluto de casos em mulheres e das taxas de mortalidade em individuos maiores de 35 anos, são fatos que devem colocar sob alerta os programas de prevençào e controle de DST/AIDS, buscando entender ate onde vai o impacto das terapias anti-retrovirais hoje existentes e que outros fatores podem influenciar a dinàmica da mortalidade por AIDS em nosso meio 


\subsection{1.b. Juvenilização ou envelhecimento?}

A AIDS aparece em todas as faixas etarias sendo mais prevalente no adulto jovem. Foram construidos os coeficientes de incidència por faixa etária $\mathrm{e}$ sexo. buscando observar a questào da juvenilização da epidemia

O que se observa e uma proporçào mais ou menos constante de casos em cada faixa etária ao longo dos anos em ambos os gèneros. No masculino, a faixa etaria dos 30-39 anos mantem-se como a que apresenta maiores coeficientes de incidencia em todo o periodo estudado, seguida pela faixa de 20-29 anos. Observase. nesta ultima faixa etária. uma tendència decrescente a partir de 1995 (figura 3), relacionada à queda dos casos entre usuarios de drogas injetáveis. que mostrou maior impacto entre os homens jovens. Há. na verdade, um ligeiro aumento das faixas etarias mais avançadas. de 40-49 e 50-59. que, se mantido, pode indicar um leve “envelhecimento" da epidemia.

Nas mulheres. ao contrário de juvenilização. há um nítido crescimento dos coeficientes de incidència na faixa etária de 30-39 (figura 4), que vem em segundo lugar ate $1994 \mathrm{e}$, depois deste ano, passa a ser a mais prevalente entre os casos de AIDS femininos As demais faixas apresentam-se na mesma proporção desde o inicio da epidemia, com tendència de crescimento dos coeficientes nas faixas dos 20 aos 49 anos

Sendo assim. não se observa no Estado de São Paulo, como um todo, o fenòmeno da juvenilização da epidemia de AIDS, e esta hipótese não pode ser confirmada pelos casos notificados no Estado de São Paulo, a menos que haja diferenças mais sutis que possam ser percebidas em determinadas regiōes geograficas ou dentro de categorias de exposição especificas ou, ainda, através da vigilància e notificaçào de individuos infectados pelo HIV os quais ainda não manifestaram sintomas da AIDS

A analise dos dados de mortalidade por AIDS, no Estado, descrita anteriormente, também aponta um deslocamento dos obitos para faixas etarias mais altas contrariando a hipótese de juvenilização e levando a crer que está havendo um envelhecimento da pessoas atingidas pela epidemia de AIDS 


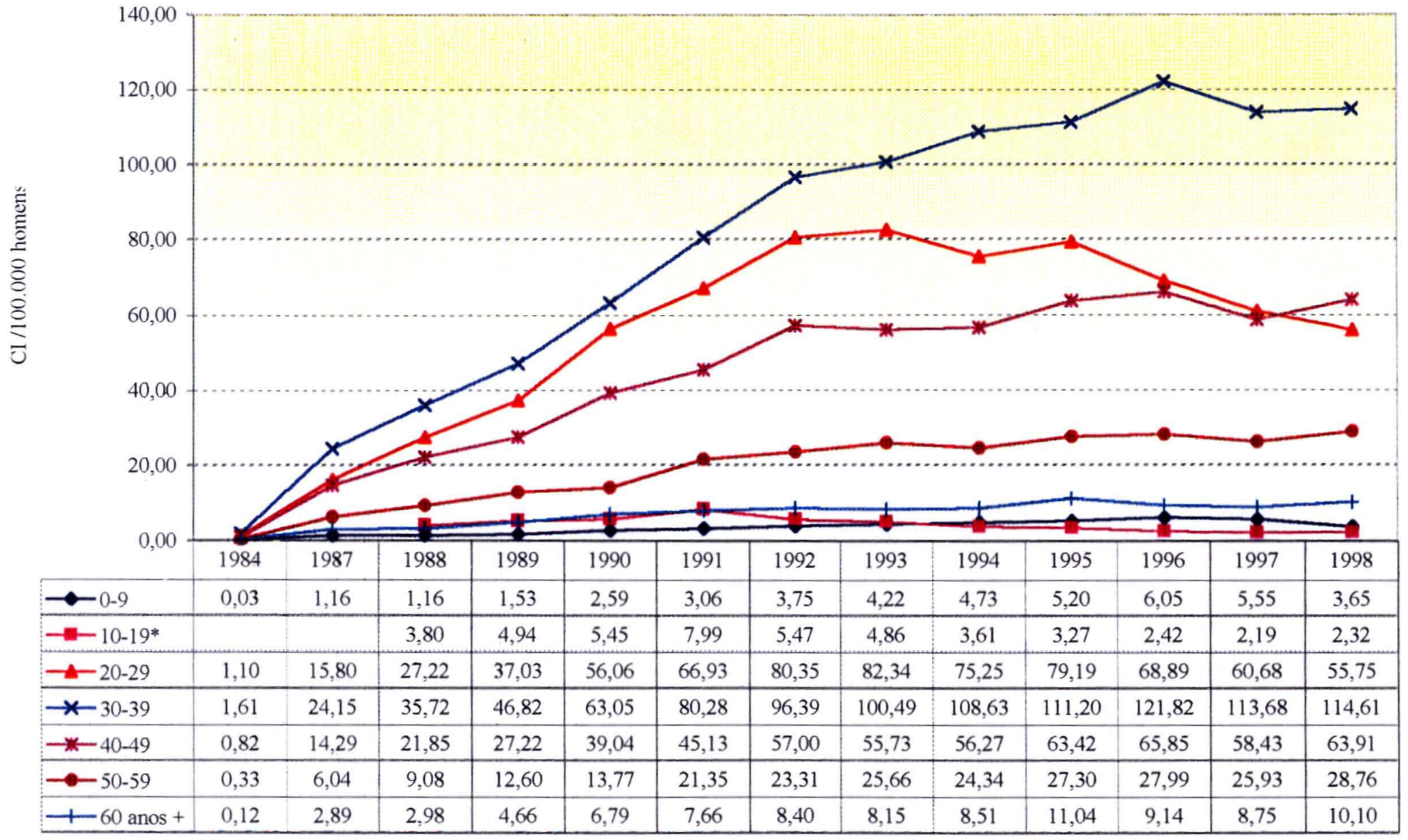

ano de diagnóstico

Figura 3. Coeficiente de Incidência (CI) no sexo masculino segundo faixa etária e ano de diagnóstico, Estado de São Paulo, 1984 a 1998(***)

Fonte:Vigilância Epidemiológica -Programa Estadual DST/Aids e *SEADE ***dados até 31/12/2001. 


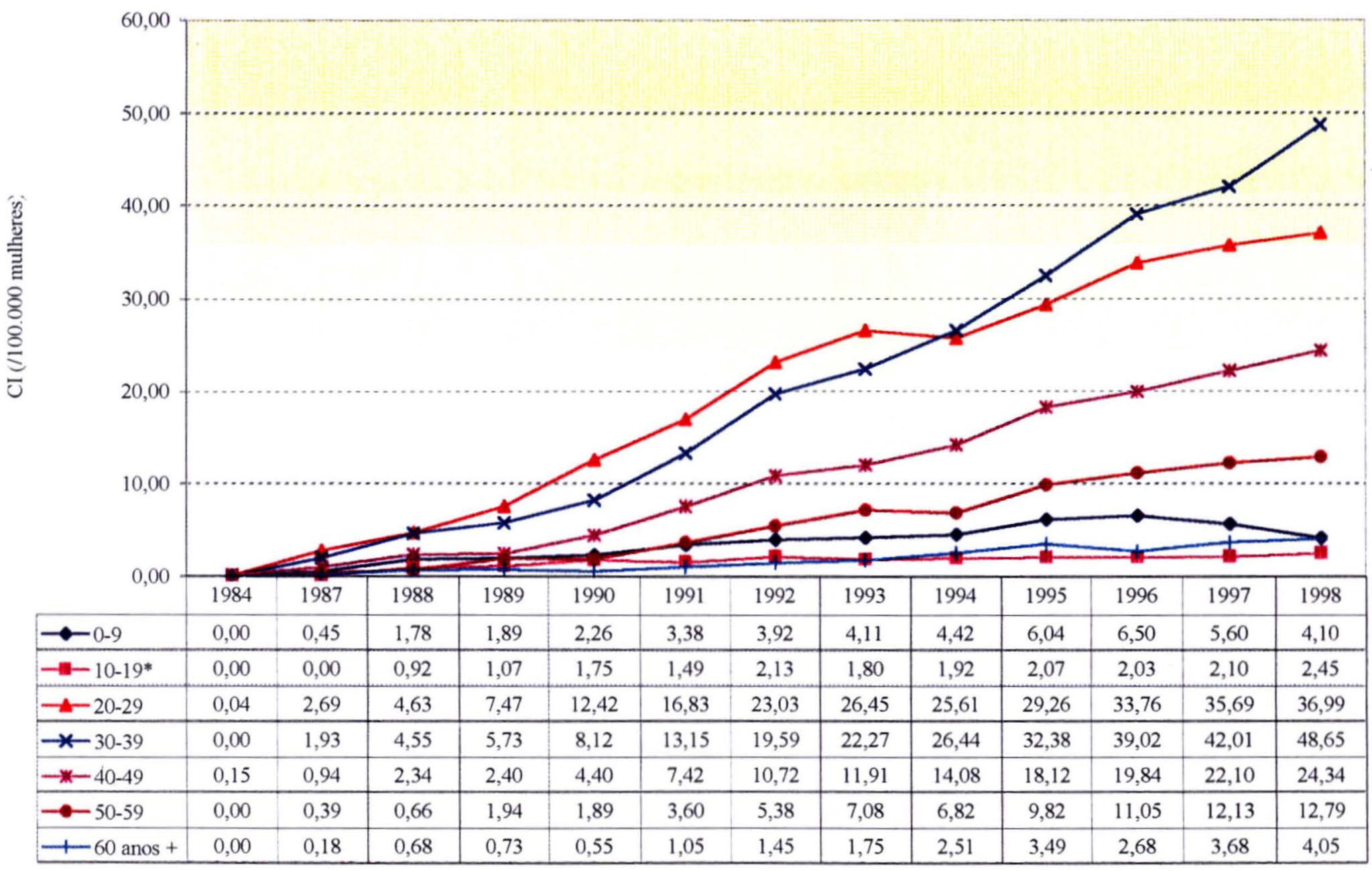

Figura 4. Coeficiente de Incidência (CI) no sexo feminino segundo faixa etária e ano de diagnóstico, Estado de São Paulo, 1984 a 1998(***)

Fonte:Vigilância Epidemiológica -Programa Estadual DST/Aids e *SEADE ***dados até 31/12/2001. 


\subsection{1. c. Pauperização}

A AIDS aparece em todas as camadas sociais. sendo que ao longo dos anos tem havido um aumento do numero de casos entre pacientes com escolaridade mais baixa e ocupações menos qualificadas. Um fato interessante de se observar é que, embora todas as categorias de transmissào apareçam entre as diversas camadas sociais, o uso de drogas injetaveis é proporcionalmente mais importante entre os pacientes com baixa escolaridade e ocupações menos qualificadas. e a transmissão sexual é proporcionalmente mais importante nos individuos de escolaridade mais alta, em ambos os sexos $(39,85)$

A escolaridade e a ocupaçào tèm sido usadas como marcadores das condições sócio-econòmicas dos pacientes com AIDS

Quanto à escolaridade dos casos notificados de AIDS, observa-se nas tabelas 8 e 9, a proporção de casos segundo o grau de instrução, para homens e mulheres. 
T. 1311.18

CASOS NOIIIIC WDOS DE AIDS LM HOMLNS MAIORI:S DE I ANOS. SLEGUNDO

ISCOI ARIDADI * I: ANODF DIACINOSTICO.FSTADODE SÃOPALT.O. 1980-2001(**) (iRAUD) ESCOI ARIDADI

\begin{tabular}{|c|c|c|c|c|c|c|c|c|}
\hline & & \multirow[b]{2}{*}{ Total } \\
\hline \multirow{2}{*}{$\begin{array}{c}\text { ANODI: } \\
\text { DIAGNOSTICO }\end{array}$} & INAIFAIBLIO & 1 (il & & 2"GR & & $S I \mathrm{PH}$ & & \\
\hline & No. & No. & $0_{0}$ & No. & $\sigma_{0}$ & No. & $\%$ & No. \\
\hline
\end{tabular}

\begin{tabular}{|c|c|c|c|c|c|c|c|c|c|c|}
\hline 1980 & - & - & - & - & 1 & 100.0 & - & - & 1 & 100.0 \\
\hline 1982 & - & - & 1 & 33.3 & 1 & 33.3 & 1 & 33.3 & 3 & 100.0 \\
\hline 1983 & - & - & 4 & 40.0 & 2 & 20.0 & 5 & 50.0 & 10 & 100.0 \\
\hline 1984 & - & - & 18 & 45.0 & 8 & 20.0 & 16 & 40.0 & 40 & 100.0 \\
\hline 1985 & 2 & 1.8 & 40 & 35.1 & 20 & 17.5 & 52 & 45.6 & 114 & 100.0 \\
\hline 1986 & 2 & 0.9 & 89 & $40 . .3$ & 48 & 21.7 & 82 & 37.1 & 221 & 100.0 \\
\hline 1987 & 17 & 2.5 & 338 & 49.3 & 150 & 21.9 & 181 & 26.4 & 686 & 100.0 \\
\hline 1988 & 22 & 1.6 & 728 & 53.6 & 302 & 22.2 & 306 & 22.5 & 1358 & 100.0 \\
\hline 1989 & 49 & 2.4 & 1177 & 58.7 & 416 & 20.8 & 362 & 18.1 & 2004 & 100.0 \\
\hline 1990 & 46 & 1.6 & 1727 & 59.2 & 636 & 21.8 & 507 & 17.4 & 2916 & 100.0 \\
\hline 1991 & 57 & 1.6 & 2247 & 61.5 & 812 & 22.2 & 539 & 14.7 & 3655 & 100.0 \\
\hline 1992 & 104 & 2.2 & 3012 & 63.6 & 992 & 21.0 & 626 & 13.2 & 4734 & 100.0 \\
\hline 1993 & 154 & 3.1 & 3190 & 64.0 & 1075 & 21.6 & 564 & 11.3 & 4983 & 100.0 \\
\hline 1994 & 143 & 2.8 & 3361 & 66.1 & 1053 & 20.7 & 527 & 10.4 & 5084 & 100.0 \\
\hline 1995 & 168 & 3.1 & 3652 & 67.2 & 1109 & 20.4 & 507 & 9.3 & 5436 & 100.0 \\
\hline 1996 & 196 & 3.6 & 3734 & 68.6 & 1026 & 18.8 & 488 & 9.0 & 5444 & 100.0 \\
\hline 1997 & 195 & 3.7 & 3633 & 69.0 & 1012 & 19.2 & 423 & 8.0 & 5263 & 100.0 \\
\hline 1998 & 165 & 3.0 & 3958 & 71.4 & 944 & 17.0 & 473 & 8.5 & 5540 & 100.0 \\
\hline 1999 & 1.36 & 2.9 & 3374 & 72.5 & 783 & 16.8 & 360 & 7.7 & 4653 & 100.0 \\
\hline 2000 & 120 & 3.1 & 2759 & 71.2 & 709 & 18.3 & 285 & 7.4 & 3873 & 100.0 \\
\hline 2001 & 53 & 3.3 & 1108 & 68.9 & 329 & 20.5 & 117 & 7.3 & 1607 & 100.0 \\
\hline IOTAL & 1629 & 2.8 & 38150 & 66.3 & 11428 & 19.9 & 6304 & 11.0 & 57511 & 100.0 \\
\hline
\end{tabular}

Fonte: Vigilancia Epidemiologica - Programa Estadual DST/Aids.

(*) Dados preliminares. sujeitos a revisão mensal. até 31/12/01

** Não incluidos 19.410 homens com escolaridade sem intormação.

Os casos masculinos tèm uma proporção muito maior de individuos de nivel superior do que as mulheres, especialmente nos primeiros anos da epidemia. Isto se deve ao fato de que, neste periodo, a categoria de exposiçào mais comum era a homossexual e que estes individuos apresentavam, em média, escolaridade muito maior do que a população em geral $(33,87)$.

Observa-se, ainda na tabela 8 , que, a partir do inicio dos anos 90 , a proporção de pessoas com primeiro grau completo e incompleto cresce entre os casos masculinos notificados, periodo este que corresponde à explosão dos casos transmitidos pelo uso de drogas injetáveis, que está sabidamente relacionada com uma parcela menos privilegiada. do ponto de vista sócio-econômico, da população $(11,39,85)$. 
Esta diminuiçào do g̣rau de instruçào dos pacientes com AIDS tem sido largamente citada como indicador de pauperizaçào $(5.33 .73 .94)$ da epidemia.

Nas mulheres. entretanto, nào ha evidència de deslocamento do grau de instrução dos casos ao longo dos anos pois, desde os primeiros anos, a maioria dos casos femininos esta entre aquelas com escolaridade menor ou igual ao primeiro grau. e a proporção de analfabetas e maior do que para os homens A proporçào de mulheres com escolaridade superior fica em torno de $+\%$, mantendo-se relativamente constante no decorrer dos anos (figuras 5 e 6).

TABII.A 9

CASOS NOTIFICAIXOS DE: AIDS MULHIERIS MAIORFS DE 12 ANOS. SFGUNIDO

ESCOL,ARIDADE* E ANO DE DIAGNOSTICO, ESTADO DE SÃOPAULO, 1980-2001(**)

\begin{tabular}{|c|c|c|c|c|c|c|c|}
\hline \multirow{3}{*}{$\begin{array}{c}\text { ANODF } \\
\text { DIACINOSTICO }\end{array}$} & \multicolumn{6}{|c|}{ (iRAU DE ESCOLARIDADE } & \multirow[b]{2}{*}{ Total } \\
\hline & ANALFABETO & I" GiRAU & 2"GRAU & & $s$ & & \\
\hline & No. & No. & No. & $\%$ & No & $\%$ & No. \\
\hline
\end{tabular}

\begin{tabular}{rrrrrrrrrrr}
1980 & - & - & - & - & - & - & - & - & - & - \\
1982 & - & - & - & - & - & - & - & - & - & - \\
1983 & - & - & 1 & 100.0 & - & - & - & - & 1 & 100.0 \\
1984 & - & - & 1 & 50.0 & 1 & 50.0 & - & - & 2 & 100.0 \\
1985 & - & - & 7 & 87.5 & 2 & 25.0 & - & - & 8 & 100.0 \\
1986 & - & - & 4 & 80.0 & 3 & 60.0 & 1 & 20.0 & 5 & 100.0 \\
1987 & 6 & 7.4 & 58 & 71.6 & 12 & 14.8 & 5 & 6.2 & 81 & 100.0 \\
1988 & 7 & 3.4 & 156 & 76.1 & 31 & 15.1 & 11 & 5.4 & 205 & 100.0 \\
1989 & 23 & 7.4 & 223 & 72.2 & 45 & 14.6 & 18 & 5.8 & 309 & 100.0 \\
1990 & 16 & 3.2 & 357 & 72.4 & 91 & 18.5 & 29 & 5.9 & 493 & 100.0 \\
1991 & 35 & 4.9 & 539 & 75.2 & 109 & 15.2 & 34 & 4.7 & 717 & 100.0 \\
1992 & 53 & 4.8 & 782 & 70.5 & 206 & 18.6 & 69 & 6.2 & 1110 & 100.0 \\
1993 & 78 & 5.7 & 984 & 72.4 & 241 & 17.7 & 56 & 4.1 & 1359 & 100.0 \\
1994 & 92 & 6.2 & 1094 & 73.6 & 236 & 15.9 & 64 & 4.3 & 1486 & 100.0 \\
1995 & 97 & 5.2 & 1350 & 72.6 & 337 & 18.1 & 76 & 4.1 & 1860 & 100.0 \\
1996 & 114 & 5.4 & 1541 & 72.8 & 374 & 17.7 & 87 & 4.1 & 2116 & 100.0 \\
1997 & 150 & 6.0 & 1858 & 74.4 & 394 & 15.8 & 95 & 3.8 & 2497 & 100.0 \\
1998 & 141 & 5.0 & 2160 & 77.1 & 394 & 14.1 & 105 & 3.8 & 2800 & 100.0 \\
1999 & 94 & 3.9 & 1872 & 77.5 & 364 & 15.1 & 86 & 3.6 & 2416 & 100.0 \\
2000 & 100 & 4.9 & 1549 & 75.8 & 317 & 15.5 & 78 & 3.8 & 2044 & 100.0 \\
2001 & 46 & 5.4 & 646 & 75.2 & 129 & 15.0 & 38 & 4.4 & 859 & 100.0 \\
$101 a 1$ & 1052 & 5.2 & 15182 & 74.5 & 3286 & 16.1 & 852 & 4.2 & 20.372 & 100.0 \\
\hline
\end{tabular}

Fonte SINAN-Vigilancia Epidemiologica - Programa Estadual DST/Aids-SP

(*) Dados preliminares sujeitos a revisào mensal ate 31/12/01

- Não incluidos 5.907 mulheres com escolaridade sem informaçăo. 

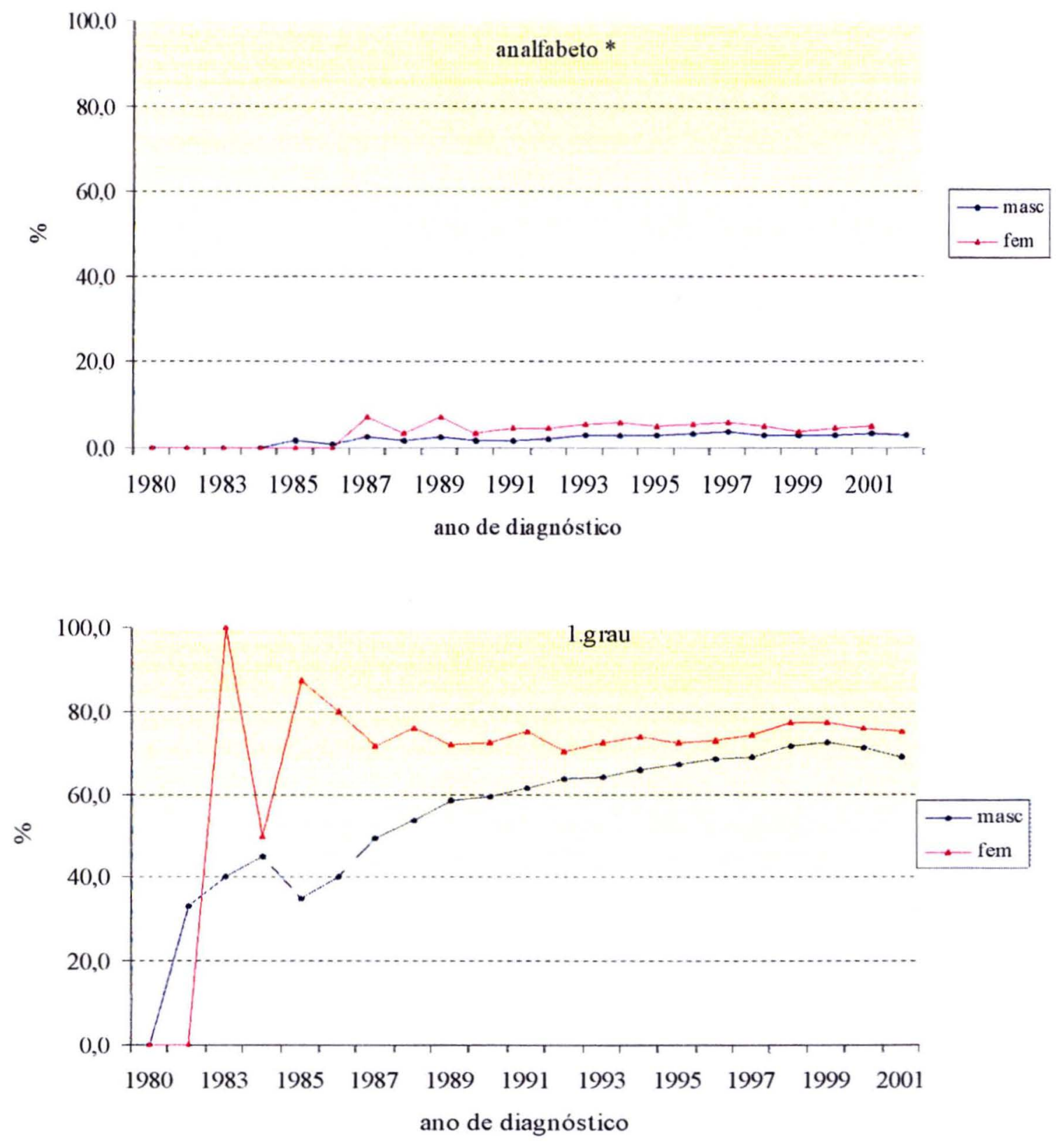

Figura 5. Proporção do nível de escolaridade - analfabeto e $1^{\circ}$ grau dos casos notificados de Aids segundo sexo e ano de diagnóstico, Estado de São Paulo, 1980 a $2001^{* *}$

Fonte: SINAN- Vigilância Epidemiológica - Programa Estadual DST/Aids-SP

(**)Dạdos preliminares, sujeitos a revisão mensal. até 31/12/01. 

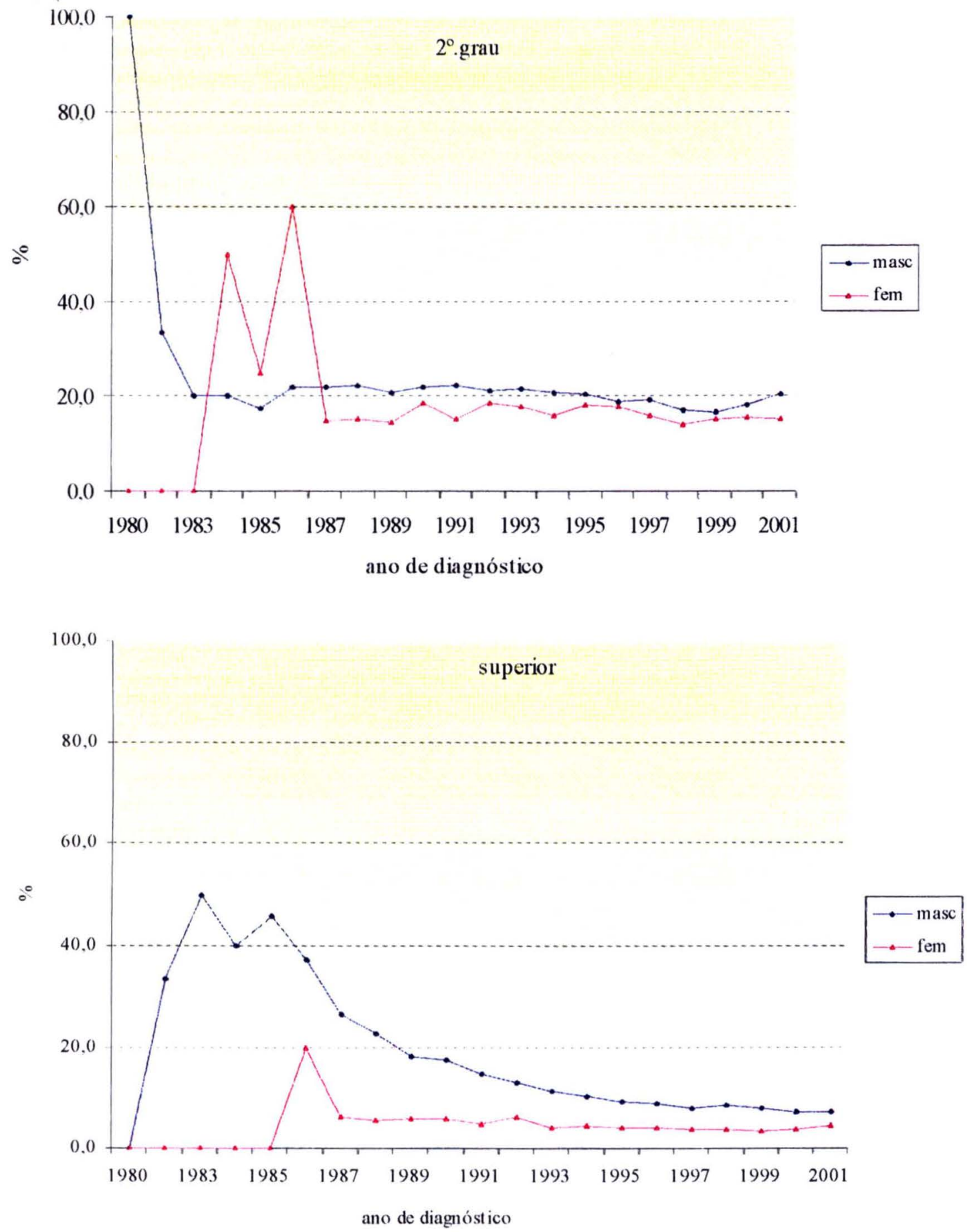

Figura 6. Proporção do nível de escolaridade - 2.o e 3.grau dos casos notificados de Aids segundo sexo e ano de diagnóstico, Estado de São Paulo, 1980 a 2001**

\section{Fonte: SINAN- Vigilância Epidemiológica - Programa Estadual DST/Aids-SP}

(**)Dados preliminares, sujeitos a revisão mensal, até 31/12/01. 
Assim a pauperização da epidemia e um fato que se observa claramente na epidemia masculina. mas nào na feminina. A epidemia de AIDS entre as mulheres esta pauperizada desde o seu inicio. mantendo entretanto uma porcentagem de casos entre as mulheres universitarias mais ou menos constante ao longo dos anos

E importante ressaltar este fato, pois o discurso da pauperização da epidemia dá às mulheres com maior escolaridade e melhor nivel sócio-econòmico uma falsa sensação de "proteção" e distanciamento da doença. Erro semelhante foi cometido no inicio da epidemia, quando o alarde sobre o fato de que a maioria dos casos ocorria em homens homossexuais. levou os demais segmentos da sociedade a se acreditarem "fora do risco". Esta crença foi. provavelmente. um dos fatores facilitadores da heterossexualização da epidemia. 


\subsection{1. d. Feminização e heterossexualização}

A epidemia de AIDS no Estado de São Paulo cresceu rapidamente, atingindo seu pico maximo de incidència entre 1995 e 1996 para os homens e. depois disto. começou a declinar. Vas mulheres apresentou ate 1998 uma tendència ascendente

Muito tem se discutido a respeito da diminuição da epidemia, o que na verdade se verifica mais claramente entre os homens e, mesmo entre estes, tomandose os individuos que referem à pratica heterossexual como categoria de exposição, há uma tendència de crescimento até 1997, acompanhando a tendência das mulheres.

Ainda que se acredite haver uma superestimativa dos casos em homens heterossexuais e que uma parcela destes homens sejam bissexuais não declarados, supõe-se que isto não aconteça na maioria dos casos e, que esta tendència represente, de fato, o modo de ocorrència da epidemia na população heterossexual masculina, até porque os homens homo e bissexuais têm apresentado um padrão de aumento e diminuição de casos semelhantes ao longo do tempo, inclusive com relação a um pequeno aumento do número de casos em 1998, contrariando a tendència de queda, ano a ano, dos individuos que relatam estas categorias de exposição.

O crescimento dos casos entre homens heterossexuais. junto ao marcante predominio desta forma de transmissão na população feminina, corrobora a hipótese de heterossexualização da epidemia

A feminização da epidemia é fato consumado. O decréscimo da razão masculino/feminino de casos e de óbitos e o fato da AIDS figurar entre as principais causas de mortalidade nas mulheres em idade fértil demonstram, inequivocamente, a magnitude com que a AIDS tem atingido nossa população feminina

Como já observado o uso de drogas injetáveis foi um fator fundamental na feminização da epidemia no Estado de São Paulo, e este mesmo fato ocorreu em outros locais do mundo, como na Europa (96) e nos EUA (23). 
Um aspecto essencial na epidemia de AIDS é que. ao contrário da fantasia da maioria da população e mesmo dos trabalhadores da saude . ela já não está restrita a "grupos de risco" específicos há muito tempo e isto é mais facilmente observado na população feminina (6.41.64.98). Uma parcela cada vez mais expressiva das pacientes notificadas de AIDS tem parceria sexual única no momento do diagnóstico e um número de parceiros sexuais na vida que não difere muito do relatado pela maioria da populaçào (67)

Há que se considerar, ainda, que o aumento do número de casos em mulheres traz, como consequência, o aumento no número de crianças com AIDS pela transmissão materno-infantil e traz à tona o problema da orfandade (93). 


\section{3. O enfoque nas mulheres}

Quanto à feminização e fundamental procurar intervir nos fatores que tornam a população feminina tão mais vulneravel à AIDS. Sabe-se que o empobrecimento, que se apresenta hoje como um fenòmeno globalizado. é ainda mais acentuado entre as mulheres.

BARBOSA (1999) coloca: "Neste contexto, a situação da população feminina é desvantajosa. Nos EUA, dois em cada très adultos que viviam abaixo do nivel de pobreza em 1983 eram mulheres. Este fenòmeno - chamado de feminização da pobreza - ocorre tanto nos paises ricos quanto nos pobres, especialmente na última década, quando o desemprego aumentou consideravelmente em quase todo o mundo" (9)

Para além da questão do empobrecimento $(47,97)$ e, intimamente ligadas a ela, estão outras questões de gênero que aumentam sobremaneira a vulnerabilidade das mulheres.

Apesar de todo o discurso de liberação feminina nas sociedades ocidentais, no que diz respeito aos direitos sexuais e reprodutivos, as mulheres ainda se encontram em grande desvantagem $(8,12,65)$ e grandes mudanças culturais e estruturais são necessárias para que se alcance a tão sonhada igualdade de direitos entre homens e mulheres

O papel da mulher ainda de submissão com relação às questões sexuais e a responsabilização das mulheres no que diz respeito às questões reprodutivas dificultam o diálogo com seus parceiros e aumentam a vulnerabilidade das mulheres.

Novamente citando BARBOSA (1999): "Fica claro que não se pode discutir a AIDS e seu enfrentamento sem compreender os papeis de gênero e todas as implicações que esses têm nas relações entre homens e mulheres. A adoção de medidas preventivas, como $\dot{e} \mathrm{o}$ caso do preservativo. esbarra em assuntos 
profundamente arraigados e sobre os quais ainda e dificil dialogar. romper barreiras (especialmente emocionais). vencer medos, enfim. entrentar abertamente uma ameaça real à vida de milhares. senão milhòes. de homens. mulheres e crianças em todo o mundo a vulnerabilidade feminina ao HIV necessariamente remete as formas como homens e mulheres se relacionam em nossa sociedade, a dinàmica de poder que perpassa tais relações e o imaginario coletivo em relação aos papéis de gènero - que, certamente, constituem importantes variáveis na conformaçào do atual perfil da epidemia" (9. p281), e em outro trecho a autora coloca: "Porém, é indiscutivel que, quando o controle da fertilidade é reduzido a informaçōes técnicas e uso de metodos. sem se discutirem a sexualidade $\mathrm{e}$ as relações de gênero, as mudanças são mais limitadas. e o poder é menos ameaçado ou, até, não ameaçado Falar sobre sexo é ameaçador. Educar os jovens para o sexo é visto como ameaçador Mudar as práticas sexuais e torná-las mais seguras é percebido como ameaçador $\dot{E}$ ameaçador para a autoridade masculina, parental, religiosa, enfim, para todos aqueles que decidiram o que é certo e o que é errado para a sociedade como um todo".

O papel de "cuidadoras", que as mulheres desempenham ate hoje na nossa sociedade. faz com que, para a maioria delas, sua primeira responsabilidade seja com a saude de suas crianças e outras pessoas na familia que possam precisar de seus cuidados (20), além de, muitas vezes, elas não se entenderem sob risco

Muitos são os aspectos especificos do atendimento às portadoras de HIV/AIDS se considerarmos as questões de gènero $(17,95)$. Para as mulheres. de uma forma geral, as decisões sexuais e reprodutivas são complexas, considerando que permeiam diversas questões fundamentais do universo feminino, tais como afetividade, desejo sexual, saúde e a reprodução propriamente dita. Para as portadoras do HIV, as decisòes reprodutivas são um dilema ainda maior, raramente colocado nas diversas instàncias onde a AIDS é foco de discussão, sejam elas governamentais ou não. Quanto à reprodução destas mulheres, apenas uma questão é colocada como relevante: a possibilidade de transmissão materno-infantil (8) 
Mas se entendermos a atençào a saude reprodutiva como um conjunto de metodos. técnicas e serviços que contribuem para a saude e o bem-estar das mulheres, prevenindo e solucionando seus problemas ligados à reprodução, e diminuindo sensivelmente a morbidade a ela associada através de programas de planejamento familiar, pré-natal e atenção ao parto e puerpério (83), veremos que em nosso meio estamos muito aquém do minimo desejado em termos desta atenção, particularmente no que se refere as mulheres HIV positivas.

Apesar do avanço da terapia anti-retroviral, temos, ainda hoje, um prognóstico relativamente reservado para os pacientes de AIDS, e a prevenção primaria da transmissão do HIV continua sendo a maneira de intervenção mais eficiente para controlar a propagação deste virus. Sendo assim, é fundamental buscarmos diminuir a vulnerabilidade $(4,5,44)$ da população, em especial das mulheres, para que elas possam realizar, efetivamente, esta forma de prevenção 


\section{4. Justificativa}

Observando-se a trajetoria da epidemia de AIDS em todo o mundo e. especialmente no nosso meio, fica patente a relevància das mulheres. particularmente as que estão em idade fértil. neste cenario

Atribui-se à reprodução um dos mais importantes papeis a serem desempenhados pelas mulheres nas diversas sociedades.

A pesquisa entre as mulheres HIV positivas nos paises industrializados sugere que o diagnóstico pode interromper a vida sexual (42), mas a maioria das mulheres e homens mantém sua atividade sexual apesar da angústia que sobrevem ao diagnóstico da infecção pelo HIV (45)

Algumas pesquisas de AIDS e de saude reprodutiva, assim como a grande maioria dos serviços de saúde, lidam. muitas vezes, com as questões relacionadas à prevenção das DST/AIDS e as especificas da saude reprodutiva, de uma forma dicotomizada. relevando o fato de que a infeç̧ào pelo HIV e a gravidez podem ocorrer nas mesmas relações sexuais em vários cenários e como resultado do mesmo "script" sexual, determinado pelas relações de gènero (72).

Muitos estudos confirmam o acesso limitado das mulheres brasileiras às informações que lhes permitiriam fazer escolhas com relação à contracepçào (43). As mulheres HIV positivas estão às voltas com estes mesmos problemas

Sabemos que o conhecimento da possibilidade de transmissão do HIV através das relações sexuais, nem sempre se traduz imediatamente em medidas preventivas com relação a esta infecção (36,84). Assim como o conhecimento dos riscos (maternos e para a criança) que podem advir de uma gestação na vigència de uma infecção pelo HIV, provavelmente também não se traduzem na adoção de métodos contraceptivos eficazes e/ou seguros. 
Que representaçào assume para as mulheres, em sua fase reprodutiva. uma infecçào tào grave quanto a produzida pelo HIV? Infecçào esta que, além de interferir de forma contundente na possibilidade da mulher se manter sadia. traz o risco de transmissão desta mesma infecção ao seu concepto e ao seu parceiro

Que repercussões a epidemia de AIDS tem sobre as decisões pró-maternidade ou de negação da mesma. nas mulheres?

Como elas podem optar pela maternidade e. ao mesmo tempo, adotar medidas preventivas com relação ao HIV?

Estão elas suficientemente orientadas quanto aos riscos e às possibilidades técnicas de prevenção da infecção pelo HIV em seus conceptos para realizarem suas opções quanto à reprodução? A mesma questão vista pelo avesso: como as mulheres que, não desejam de forma alguma ter filhos, são orientadas para conseguirem este objetivo?

Estas são algumas das indagações que nos levaram a propor um trabalho, onde as mulheres que protagonizam estas situações pudessem ter espaço e voz para colocarem suas expectativas, experiências e propostas. 
OBJETIVOS 


\section{OB.JETIVOS}

\subsection{Objetivo Geral}

- Avaliar o modo pelo qual a infecçào pelo HIV afeta as decisões reprodutivas das mulheres por ela atingidas

\subsection{Objetivos Especificos}

- Estimar a proporção de mulheres HIV positivas que pensam em ter filhos

- Estudar algumas variaveis tais quais o uso de contraceptivos, número de filhos, existência de parceiro fixo, percepção de risco e outras que possam estar associadas às decisões reprodutivas destas mulheres 
MÉTODO 


\section{MÉTODO}

\subsection{Pesquisa realizada com 148 mulheres soropositivas para o HIV.}

Realizamos uma pesquisa com mulheres HIV positivas, clientes do ambulatório do CRT-DST-AIDS de São Paulo, uma instituição pública da Secretaria de Estado da Saúde de São Paulo. sede do Programa Estadual de DST/AIDS, especializada no atendimento a individuos portadores de HIV/AIDS e outras DST.

Esta pesquisa. denominada "Barriers to acess and adherence to AIDS early care among HIV positive women in São Paulo, Brazil" foi realizada como resultado de uma parceria entre três instituições: O CRT-DST-AIDS , o NEPAIDS (Núcleo de Estudos para Prevenção de AIDS, da Universidade de São Paulo) e a Universidade da Califórnia.

Realizamos um estudo exploratório, cujo instrumento elaborado para a coleta de informações foi um questionário semi-estruturado, aplicado através de entrevistadoras treinadas (duas médicas, cinco psicólogas e cinco estagiárias de psicologia)

Este questionário (anexo 1) continha perguntas fechadas e abertas, e descrevia caracteristicas sócio demográficas como idade, escolaridade, raça, ocupação. dependência econòmica, acesso ao serviço de saúde e a relação das mulheres com os profissionais do serviço. Além disto, as mulheres foram questionadas sobre as formas de conhecimento de seu estado sorológico, fatores de risco para o HIV, percepção de risco antes de se saberem HIV positivas, comportamento sexual e reprodutivo e aderència aos métodos de prevenção secundária e medicamentos preconizados pelo serviço.

Neste instrumento foram introduzidas questões sobre vida reprodutiva e anticoncepção com a finalidade precipua de obter dados para a análise que aqui se propõe. 
As mulheres foram recrutadas. pelas entrevistadoras. no periodo de agosto a dezembro de 1997. na sala de espera dos consultórios dos diversos profissionais do serviço ambulatorial do CRT-DST-AIDS

Foi oferecida. a todas aquelas que compareceram ao ambulatorio no periodo do estudo, a possibilidade de participar do mesmo. excluindo-se as debilitadas fisicamente, as menores de 18 anos. as mulheres que estavam indo ao serviço em busca de atenção medica para seus filhos e as que haviam participado de outros estudos exploratórios recentemente no CRT-DST-AIDS, pois estes fatores poderiam constituir-se em desconforto para a participaçào destas mulheres ou influenciar nas respostas obtidas.

Obtivemos assim uma amostra consecutiva. nào probabilistica.

Foram entrevistadas 148 mulheres às quais consentiram em responder ao questionário

A taxa de recusa foi em torno de $17 \%$. A falta de disponibilidade de tempo para a entrevista, não gostar de se expor ou falar de coisas pessoais e "não estar a fim" de participar de pesquisas foram os motivos mais frequentes para as recusas.

No momento da entrevista, foram discutidos com todas elas os aspectos éticos da pesquisa, e o cuidado na utilização das informações, de modo que, em nenhum momento fossem citados nomes ou outras formas de identificação pessoal. Explicou-se, ainda, o tempo necessário para responder o questionario era de aproximadamente uma hora e deu-se as mulheres um termo de consentimento (anexo 2), em duas vias, onde constava a maioria das orientações verbais antes colocadas. As mulheres liam o consentimento, assinavam e mantinham consigo uma cópia. A outra copia era entregue à entrevistadora

Foi, ainda, colocado o seguinte: a possivel participação delas em grupos de apoio a serem realizados no seguimento da pesquisa e o acesso à abordagem terapèutica individual e de grupo com as psicólogas do serviço, caso necessitassem. Foi-lhes assegurado que não perderiam quaisquer direitos no CRT-DST-AIDS, como por exemplo, qualquer tratamento oferecido, caso não quisessem participar do estudo 
Os resultados $\mathrm{e}$ analises preliminares foram apresentadas para as mulheres que participaram do estudo. antes de qualquer outra apresentaçào. como parte do processo de seguimento do trabalho. Este processo incluiu grupos institucionais e de suporte para as mesmas.

Organizamos très diferentes grupos de suporte. abertos a todas as participantes do estudo: um grupo informativo. um grupo para discutir formas de diminuir o estresse e um grupo de arte-terapia.

Estes grupos foram realizados com a finalidade de dar a estas mulheres acesso a informações importantes na realizaçào da prevenção secundaria. como opções de tratamento e sexo seguro, também formas relevantes de prevenção, nem sempre enfatizadas, especialmente entre mulheres que não são trabalhadoras do sexo. E, ainda, discussões sobre discriminação, preconceito, relações familiares e aspectos legais ligados ao fato de serem soropositivas para o HIV.

Os grupos de arte-terapia e diminuição do estresse tinham a finalidade especifica de dar a elas a oportunidade de colocarem suas questões mais conflitantes naquele momento e de discutirem formas de minimizar estes conflitos, tanto quanto possivel

Cada um destes grupos foi conduzido por, pelo menos, duas investigadoras e uma estagiária de psicologia, que atuou como anotadora das questões discutidas. produzindo, posteriormente. relatórios destes encontros.

Os dados obtidos das entrevistas foram armazenados em um banco de dados em SPSS. Os questionários foram previamente codificados antes de sua digitação. As respostas das questões abertas foram também codificadas e incluidas neste banco de dados. após terem sido categorizadas tomando-se a idéia principal do discurso.

$A$ análise quantitativa dos dados foi realizada utilizando-se o Epi-Info e $o$ SPSS

A variável dependente do estudo foi "pensa em ter filhos". Para estudar a associação desta com outras variáveis, selecionamos as mulheres com menos de 50 anos. excluindo as esterilizadas. neste grupo etário. Acreditamos, assim, estar mantendo as mulheres que, se quisessem, teriam maiores possibilidades de concretizar a idéia de uma gestação. 
Foram utilizados os testes do qui-quadrado (Yates corrigido). o exato de Fisher e o t-Student para diferença de duas medias. Para aplicação dos testes reagrupamos todas as variaveis com mais de duas categorias. simplificando-as e transformando-as. sempre que possível. em variáveis dicotòmicas.

Para avaliar a proporção das mulheres HIV positivas que pensam em ter filhos foi calculado o intervalo de confiança exato de $95 \%$ para a prevalència

As respostas das questões abaixo descritas, foram selecionadas para auxiliar a análise dos dados relativos ao desejo de ter filhos, anticoncepção e percepção de risco

9 a. Você tem filhos? - questão fechada, sim ou não.

9 e. HIV+? - quadro para se colocar a sequência de filhos, especificando sexo, idade. se moram com a entrevistada e se são HIV+.

$10 \mathrm{a}$. Vocè antes de ir fazer o teste já tinha pensado que podia ser HIV positiva?

- questão fechada, sim ou não.

$10 \mathrm{~b}$. Por què? - questão aberta.

$10 \mathrm{~d}$. Como ficou sabendo que era HIV+? - questão aberta.

11 i. Vocè pensa em ter filhos? - questão fechada, sim ou não.

11 j. Por quê? - questão aberta.

$11 \mathrm{k}$. Como acha que seria a reação das pessoas que cercam vocè se decidisse ter filhos? - questão aberta.

111. Você concorda com eles? - questão aberta

$11 \mathrm{~m}$. Vocè fícou grávida depois de estar HIV positiva? - questão aberta.

11 p. Usou anticonceptivo para evitar filho depois de se saber portadora do HIV?

- questão fechada, sim ou nào.

11 q. Se sim, qual ? - questão estruturada, com relação dos métodos anticonceptivos.

$16 \mathrm{~b}$. O que mantém vocè lutando? - questão aberta

$16 \mathrm{c}$. Pensando que exista a possibilidade de vocè faltar a seus filhos, ja pensou como encaminhar as coisas em relaçào a eles? - questão aberta

Foram revisadas todas as entrevistas copiando-se o conteúdo das questões acima colocadas, quase sempre literalmente. e, algumas vezes. tomando-se apenas a idéia central da resposta. para ilustrar a análise. 
Observando as respostas das questões lli (Vocè pensa em ter filhos?) e Ilj (Por quê??) vimos que varias vezes o motivo alegado pelas mulheres na questào $11 \mathrm{j}$ não condizia com a resposta anterior (11i). Exemplificando. varias mulheres que responderam não pensar em ter filhos, ao questionadas o porquè. forneciam respostas do tipo "meu maior sonho sempre foi ter filhos. mas tenho medo por causa do HIV". demonstrando. claramente, o desejo de ter filhos, frustado pelo fato de serem soropositivas para o HIV.

Entendendo que o "pensar em ter filhos" e o "desejo de ter filhos" podem ter concepções diferentes e, com o intuito de esmiuçar o tema. criamos, para as 148 mulheres. independentemente da possibilidade biológica de ter filhos ou não, uma nova variảvel denominada "desejo" a partir do cruzamento das questões $11 \mathrm{i}$ e $1 \mathrm{lj}$, obedecendo a seguinte categorização:

1 - sim consistente - para as mulheres que responderam sim à questão $11 \mathrm{i}$ e na resposta $11 \mathrm{j}$ expressavam os motivos pelos quais queriam ter filhos.

2 - não inconsistente, entendido como sim - para as mulheres que responderam não à questão 1 li e na resposta $11 \mathrm{j}$ expressavam claramente que desejavam muito ter filhos.

3 - não inconsistente - para as mulheres que responderam não à questão $11 \mathrm{li}$ e na resposta $1 \mathrm{lj}$ diziam que a infecção pelo HIV era o motivo pelo qual não pensavam em ter filhos, sem entretanto expressar claramente o desejo de tè-los.

4 - sim inconsistente - para as mulheres que responderam sim à questão $11 \mathrm{l}$ e na resposta $1 \mathrm{lj}$ expressavam que não queriam ter filhos de forma alguma.

5 - não consistente - para as mulheres que responderam não à questão $11 \mathrm{i}$ e na resposta $11 \mathrm{j}$ reiteravam a idéia de não desejar ter filhos.

A partir da construção desta nova variável, agrupamos os itens 1,2 e 3 considerando-os como "sim" da variável desejo, e os grupos 4 e 5 considerando-os como "não".

Medimos a associação das variáveis: idade, ter filhos, número de filhos vivos. morar com filho, ter filhos HIV +, situação sorológica do parceiro, uso de métodos contraceptivos, uso de proteção nas relações sexuais, estado conjugal e ter relatado abuso sexual com a variável desejo, utilizando o qui-quadrado (Yates corrigido) ou o teste exato de Fisher. 


\section{RESLLTADOS}

\subsection{Perfil sócio-demográfico}

As mulheres que participaram deste estudo, tendo sido recrutadas em um serviço de referência, vieram de diferentes pontos da cidade

Havia mulheres de todas as idades. variando de 19 a 63 anos. A media de idade foi de 32,6 anos e a mediana foi de 32 anos

Quanto à religião: 22 mulheres $(14,9 \%)$ se declararam atéias, 68 mulheres $(45,9 \%)$ se declararam católicas, $33(22,3 \%)$ evangélicas e $25(16,9 \%)$ referiram outras religiões (espirita, candomblé e budista). Do total de mulheres, $88 \%$ declarou ser a religiào uma coisa importante em suas vidas.

Em termos de escolaridade. 4 mulheres $(2,7 \%)$ não tinham nenhuma escolaridade. destas 4, uma referia saber ler e escrever sem ter ido à escola e as outras 3 eram analfabetas: $17 \%$ das mulheres tinham de 1 a 4 anos de escolaridade; $42,5 \%$ tinham de 5 a 8 anos, $25,6 \%$ de 9 a 11 anos e os restantes $12,2 \%$ tinham nivel superior

Resumindo, 92 das 148 mulheres $(62,2 \%)$ tinham no máximo até o primeiro grau; 18 mulheres chegaram a fazer algum curso superior, sendo que exatamente metade delas $(6,1 \%$ do total) tinham o curso superior completo.

Um terço (51 mulheres, $34,5 \%$ ) nào possuia renda própria; $32,8 \%$ era responsável por até $50 \%$ da renda familiar, enquanto outro terço $(32,7 \%$ das mulheres) era responsavel por mais da metade da renda familiar. Dentre estas, 28 mulheres ( $20 \%$ do total) respondiam por mais de $75 \%$ dos ganhos da familia.

Das 95 mulheres que referiram renda propria, 8,4\% ganhavam menos de um salário minimo, $45,2 \%$ de 1 a 3 salários minimos; $24,2 \%$ de 3 a 5 e $22,2 \%$ percebiam mais de 5 salários minimos mensais. Duas mulheres não responderam esta questão.

Com relação à renda familiar (tabela 10 ) obtivemos informação de 131 mulheres, as demais não souberam ou não quiseram responder a pergunta. 


\section{TABELA 10}

Número e porcentagem de mulheres segundo a renda familiar em salários minimos.

CRT-DST/AIDS. 1997

\begin{tabular}{lcc}
\hline Renda familiar & No & $\%$ \\
\hline Nenhuma renda & 5 & 3.4 \\
Menos que 1 salário minimo & 1 & 0.7 \\
I a 3 salários minimos & 26 & 17,6 \\
3 a 5 salários minimos & 26 & 17,6 \\
5 a 10 salários minimos & 31 & 20.9 \\
Mais de 10 salários minimos & 42 & 28,4 \\
Não sabe & 4 & 2.7 \\
Não respondeu & 13 & 8.7 \\
\hline TOTAL & 148 & 100 \\
\hline
\end{tabular}

Quanto à inserçào destas mulheres no mercado de trabalho, apenas 42 $(28,3 \%)$ tinha emprego regular; 68 mulheres $(45,9 \%)$ estavam desempregadas: $18(12,2 \%)$ referiram fazer apenas "bicos" e $18(12,2 \%)$ estavam aposentadas. Duas mulheres $(1,4 \%)$ disseram que, apesar de aposentadas, faziam "bicos" para complementarem sua renda

A maioria das mulheres que estava procurando emprego tinha muito medo do preconceito. Somente $2 \%$ delas foram trabalhadoras do sexo ou trabalharam em clubes noturnos.

Quanto ao quesito cor, auto referida, 86 mulheres $(58,1 \%)$ se descreveram como branca; $36.5 \%$ como negras ou pardas: $1(0,7 \%)$ como amarela e $4,7 \%$ (7) como "outros".

Quanto ao estado marital: 48 mulheres $(32,4 \%)$ eram casadas ou viviam maritalmente; $44(29,7 \%)$ eram viúvas. Dentre as viúvas, 40 delas perderam seus parceiros porque morreram de AIDS. $42(28,4 \%)$ eram solteiras e $14(9,5 \%)$ separadas. 


\section{2. Número de parceiros sexuais e atividade sexual destas mulheres}

A média de idade para a primeira relaçào sexual foi 17.5 anos

Com relaçào ao abuso. $32(21.6 \%)$ mulheres relataram ter sido vítimas de abuso sexual pelo menos uma vez (aqui definido como realização de sexo contra a vontade da mulher ou pelo uso de violência).

O número de parceiros que tiveram desde o inicio de sua vida sexual até o momento da entrevista pode ser visto na tabela 11

\section{TABELA 11:}

Número e porcentagem de mulheres segundo o número de parceiros sexuais na vida, CRT-DST/AIDS, 1997

\begin{tabular}{lcc}
\hline No. de parceiros sexuais & No. & $\%$ \\
\hline Parceiro único & 15 & 10,1 \\
2 a 3 parceiros & 44 & 29,7 \\
4 a 5 parceiros & 30 & 20,2 \\
6 a 10 parceiros & 24 & 16,2 \\
10 a 20 parceiros & 9 & 6,1 \\
20 a 40 parceiros & 5 & 3,5 \\
Mais ou menos 300 & 1 & 0,7 \\
Muitos. não sabe quantos & 17 & 11.5 \\
Não responderam & 3 & 2,0 \\
\hline TOTAL & 148 & 100 \\
\hline
\end{tabular}

Trabalhando-se com as porcentagens acumuladas temos que cerca de $62 \%$ das mulheres teve ate 5 parceiros na vida, $78 \%$ ate 10 parceiros e cerca de $15 \%$ das mulheres relatou mais do que 20 parceiros. A mediana do número de parceiros na vida foi quatro e estes eram, quase sempre, parceiros fixos.

A média não se mostrou um bom indicador para representar o número de parceiros da amostra, tendo sido muito alta ( 17.7 parc.) pelo elevado número de parceiros colocado por algumas mulheres. 
Desde que souberam de sua soropositividade para o HIV. menos da metade das 148 mulheres mantem vida sexual ativa. embora mais da metade tenha relatado o desejo de fazer sexo (tabelas 12 e 13 )

TABELA 12:

Número e porcentagem de mulheres segundo o desejo de fazer sexo. CRT DST/AIDS. 1997.

\begin{tabular}{ccc}
\hline Vontade de fazer sexo & No. & $\%$ \\
\hline Sim & 74 & 50,0 \\
Não & 58 & 39,2 \\
Às vezes & 14 & 9,5 \\
Ignorado & 2 & 1,4 \\
\hline TOTAL & 148 & 100,0
\end{tabular}

TABELA 13:

Número e porcentagem de mulheres segundo a existència de relações sexuais, CRTDST/AIDS, 1997

\begin{tabular}{ccc}
\hline Você faz sexo? & No & $\%$ \\
\hline Sim & 65 & 43,9 \\
muito pouco & 10 & 6,8 \\
Não tem parceiro & 73 & 49,3 \\
\hline TOTAL & 148 & 100,0 \\
\hline
\end{tabular}

Das mulheres, apenas 19\% sentia-se confortável com relação ao sexo, enquanto a maioria delas disse que o HIV mudou tudo em sua vida sexual dado o medo de contaminar seus parceiros. Elas referiram muitas novas fontes de estresse o que fez com que perdessem parte de seu apetite sexual. ou com que se sentissem menos sensuais

Muitas das mulheres solteiras relataram o temor da situação de ter que contar a um novo companheiro que são soropositivas e de serem abandonadas em consequêencia disto. Este conceito e temor fazem com que muitas mulheres sintam o desejo de encontrar um parceiro também soropositivo para o HIV. 
Das 148 mulheres. $75\left(50.7^{\circ} \%\right)$ tinham parceiro sexual no momento da entrevista. Destas. $41 \%$ tinham relaçòes sexuais mais de uma vez por semana. $30 \%$ uma vez por semana e $29 \%$ menos frequentemente. Das mulheres sexualmente ativas. $88 \%$ eram monogàmicas.

Ainda com relação a estas 75 mulheres. 30 delas $(40 \%)$ tinham parceiros tambem soropositivos para o HIV. outras 30 tinham parceiros sabidamente negativos e 15 delas $(20 \%)$ não conheciam a situação sorológica de seus parceiros.

A grande maioria das mulheres pesquisadas $(68,1 \%)$ adquiriu a infecçào pelo HIV de seu parceiro fixo, ainda presente ou anterior. A tabela 14 descreve a categoria de exposição das 148 mulheres. Ressalta-se a importància da parceria sexual com usuários de drogas injetáveis (UDI) enquanto situação de risco.

\section{TABELA 14}

Vúmero e porcentagem de mulheres por categoria de transmissão do HIV. CRT-

DST/AIDS, 1997

\begin{tabular}{lcc}
\hline Categoria de transmissão & No. & $\%$ \\
\hline Parceiro transfundido & 3 & 2,0 \\
Parceiro UDI & 44 & 29,7 \\
Parceiro bissexual & 6 & 4,1 \\
Parc. com múltiplas parceiras & 31 & 20,9 \\
Parc risco desconhecido & 17 & 11,4 \\
Usuária Drogas Injetáveis & 7 & 4,7 \\
Múltiplos parceiros & 9 & 6,1 \\
Transfusão sanguinea & 10 & 6,7 \\
Riscos múltiplos & 13 & 9,0 \\
Ignorado & 8 & 5,4 \\
\hline TOTAL & 148 & 100 \\
\hline
\end{tabular}

Algumas mulheres relataram que não conseguiam convencer seus parceiros a fazer uso regular de preservativos, mesmo estando eles cientes do fato de elas serem infectadas pelo HIV 
Va tabela 15 temos a intormação de 65 mulheres sobre a consistencia no uso de preservativos com seus parceiros sexuais. Apenas 38 relataram uso constante de preservativos e. destas. $22(57.8 \%)$ tèm parceiros soronegativos para o HIV. Das 27 mulheres que referiram nào usar preservativo consistentemente. somente uma tinha um parceiro que não sabia que ela é HIV positiva

\section{TABELA 15}

Número de mulheres segundo o uso de preservativos e situação sorológica do parceiro, CRT- DST/AIDS. 1997.

Uso de

Preservativos

Situação sorológica parceiro

Total

\begin{tabular}{ccccccc}
\cline { 2 - 4 } & Positivo & Negativo & Desconhecido & No & $\%$ \\
\hline Nunca & 11 & 2 & 3 & 16 & 24,6 \\
Raramente & 2 & - & 3 & 5 & 7,7 \\
As vezes & 2 & 4 & - & 6 & 9.2 \\
Sempre & 11 & 22 & 5 & 38 & 58,5 \\
\hline TOTAL & 26 & 28 & 11 & $65^{*}$ & 100,0
\end{tabular}

*Obs: Informação ignorada $\mathrm{em}+$ mulheres com parceiros positivos. 2 com parceiros negativos e + com parceiros com sorologia desconhecida.

Agrupando a variavel uso de preservativos em duas: uso consistente (sempre), e inconsistente (nunca + raramente + às vezes) e considerando apenas as mulheres cujos parceiro tinham sorologia conhecida. obtivemos 26 mulheres com parceiros positivos, das quais 11 usam preservativos consistentemente e 15 não usam e 28 mulheres com parceiros negativos, das quais 22 usam e 6 não usam. Aplicando o qui-quadrado observamos uma associaçào significante $\left(\chi^{2}=6,01\right.$-Yates corrigido com $p=0,0142$ ) entre o uso consistente de preservativo e situação sorológica do parceiro. As mulheres com parceiros soropositivos tendem a fazer uso inconsistente do preservativo com uma frequència muito maior do que as mulheres com parceiros soronegativos, assim como estas últimas usam consistentemente o preservativo em uma proporção muito maior do que as primeiras

Nove mulheres $(6,1 \%)$ relataram parceiros sexuais eventuais, destas 8 reportaram usar sempre o preservativo com estes parceiros e uma referiu usar preservativo na maioria das relações sexuais. 


\subsection{A percepção de risco}

Das 148 mulheres entrevistadas. $70(47.3 \%)$ responderam que ja tinham pensado que podiam ser positivas para o HIV antes de realizar o teste. Na tabela 16 podemos observar os motivos pelos quais elas ja haviam avaliado a possibilidade de estarem infectadas As outras 78 mulheres $(52.7 \%)$ responderam que nunca pensaram nesta possibilidade. e os motivos por elas alegados estão na tabela 17.

\section{TABELA 16}

Número e porcentagem de mulheres segundo os motivos pelos quais pensaram que podiam ser HIV positivas antes de fazer o teste. CRT-DST/AIDS. 1997.

\begin{tabular}{lcc}
\hline $\begin{array}{l}\text { Motivos pelos quais pensaram que } \\
\text { podiam ser HIV positivas }\end{array}$ & No & $\%$ \\
\hline O parceiro ficou doente & 24 & 34,2 \\
O parceiro disse ser HIV+ & 9 & 12,8 \\
O parceiro era bissexual & 3 & 4,3 \\
O parceiro tinha muitas parceiras & 4 & 5,7 \\
O parceiro era UDI & 12 & 17,1 \\
Ela propria ficou doente & 7 & 10 \\
Ela teve muitos parceiros & 4 & 5,7 \\
Ela era UDI & 2 & 2,9 \\
Ela recebeu transfusão sanguinea & 2 & 2,9 \\
"Porque todo mundo tem risco" & 1 & 1,5 \\
Mais de um motivo & 2 & 2,9 \\
\hline TOTAL & 70 & 100 \\
\hline
\end{tabular}




\section{TABELA 17:}

Número e porcentagem de mulheres segundo os motivos pelos quais nunca pensaram que podiam ser HIV positivas antes de fazer o teste. CRT-DST/AIDS. 1997.

\begin{tabular}{lcc}
\hline $\begin{array}{l}\text { Motivos pelos quais nunca } \\
\text { pensaram que podiam ser HIV } \\
\text { positivas }\end{array}$ & No. & $\%$ \\
\hline Nunca imaginei, nem de longe & 31 & 39,7 \\
Não sou do grupo de risco & 19 & 24,4 \\
Confiava no parceiro & 5 & 6,4 \\
Não conhecia formas de contágio & 3 & 3,8 \\
Desconheciam a doença & 2 & 2,6 \\
Tinham teste anterior negativo & 2 & 2,6 \\
Outros & 16 & 20,5 \\
\hline TOTAL & 78 & 100 \\
\hline
\end{tabular}

E importante ressaltar que, entre as mulheres que se perceberam sob risco, porque seus parceiros poderiam ser HIV positivos por serem UDI ou terem multiplicidade de parceiras, nenhuma teve uma postura concreta de prevenção com relação à infecção pelo HIV.

Embora este dado não tenha sido mensurado. nas entrevistas, algumas mulheres referiram ter discutido com seus parceiros a necessidade de usarem preservativos pela existència do risco, mas os parceiros não aceitaram a idéia $\mathrm{e}$ elas aquiesceram.

Lembre-se ainda que, sabendo da sua condição de soropositivas e da recomendação de usar preservativos em todas as relações sexuais para impedir a reinfecção, das mulheres que têm parceria sexual fixa, $41,5 \%$ não usa preservativos ou faz uso inconsistente dos mesmos e, apenas, $58,5 \%$ refere usar preservativos sempre, como foi descrito, anteriormente, na tabela 15 . 


\section{4. Anticoncepção, proteção dupla e planejamento familiar}

Antes do diagnostico da infecção pelo HIV. 62.6\% das mulheres usavam metodos anticoncepcionais para limitar o numero de filhos. Destas. dois terços usavam metodos hormonais

Os métodos anticoncepcionais mudaram radicalmente quando as mulheres souberam ser HIV positivas, como mostra a tabela 18. Houve uma passagem do predominio dos anticonceptivos hormonais para o preservativo, após o conhecimento da soropositividade para o HIV nestas mulheres

TABELA 18

Contraceptivos e métodos de proteção dupla usados pelas mulheres antes e depois do diagnóstico do HIV. CRT-DST/AIDS, 1997.

\begin{tabular}{lcccc}
\hline Métodos contraceptivos & \multicolumn{2}{c}{ Antes do HIV } & \multicolumn{2}{c}{ Depois do HIV } \\
& N. $^{\mathbf{0}}$ & $\mathbf{\%}$ & $\mathbf{N .}^{\mathbf{0}}$ & $\mathbf{\%}$ \\
\hline Esterilização & 14 & 9,5 & 7 & 4,7 \\
Pilula anticoncepcional & 57 & 38,6 & 7 & 4,7 \\
Tabelinha & 2 & 1,3 & 3 & 2,0 \\
Coito interrompido & - & - & 3 & 2,0 \\
Hormònio injetável & 7 & 4,7 & 2 & 1,3 \\
DIU & 4 & 2,6 & - & - \\
Métodos de proteção dupla & & & & \\
Preservativo somente & 6 & 4,1 & 57 & 38,7 \\
Preservativo + Horm. Injetável & - & - & 4 & 2,6 \\
Preservativo + Pilula & 6 & 4,1 & 3 & 2,0 \\
Preservativo + Tabelinha & 2 & 1,3 & 1 & 0,7 \\
Preservativo + Coito interrompido & - & - & 1 & 0,7 \\
Preservativo + Esterilização & - & - & 1 & 0,7 \\
Sub-Total usando algum método & $\mathbf{9 8}$ & $\mathbf{6 6 , 2}$ & $\mathbf{8 9}$ & $\mathbf{6 0 , 1}$ \\
\hline Não se aplica/ não respondeu & 50 & 33,8 & 59 & 39,9 \\
\hline Total & $\mathbf{1 4 8}$ & $\mathbf{1 0 0}$ & $\mathbf{1 4 8}$ & $\mathbf{1 0 0}$ \\
\hline
\end{tabular}


Uma alta porcentagem das mulheres, as quais usavam algum outro metodo anticonceptivo antes do diagnostico do HIV, estava. agora. usando preservativos isoladamente e um numero ainda menor estava usando preservativos e mais um outro método anticonceptivo. A grande maioria das mulheres não conhecia o preservativo feminino, nem o diafragma.

Além disto, 34 mulheres $(23.1 \%)$ relataram ter tido pelo menos um aborto espontàneo, sendo que $43(29,0 \%)$ já provocaram um aborto. Vinte, das 148 mulheres, relataram abortos apos o diagnostico do HIV. Entre estas, 6 declararam ter provocado este aborto. A comparação deste dado, com a população feminina geral, não é făcil, dada a dificuldade de se obter informações precisas sobre aborto, em nosso pais, pela ilegalidade do método(90)

\section{5. Filhos e transmissão materno-infantil.}

A maioria das mulheres ( 119 ou $76 \%$ ) tem filhos e $84 \%$ delas tèm filhos menores de 13 anos. A média do número de filhos é dois.

Das 119 que tinham filhos, 36 os tiveram depois de serem HIV positivas. A imensa maioria destas mulheres não foi beneficiada pela politica de livre acesso ao tratamento com AZT durante o parto, usado desde 1996 para reduzir a transmissão materno - infantil do HIV. Sendo assim, das 44 crianças nascidas de 36 mulheres HIV positivas ( $25 \%$ das 148 mulheres), 16 crianças foram positivas, apresentando uma taxa de transmissão materno-infantil de $36 \%$. Todas, exceto uma, das 16 mães das crianças soropositivas para o HIV, souberam sua sorologia quando estavam grávidas ou quando suas crianças ficaram doentes.

No momento da pesquisa 6 mulheres $(4,0 \%)$ estavam grávidas. 


\section{6. I perspectiva da maternidade}

O desejo de ter filhos e com certeza a questão mais pungente deste trabalho e foi colocado explicitamente por 31 das 148 mulheres entrevistadas. Isto e. quando questionadas se pensam ou nào em ter filhos. $31(20,9 \%)$ responderam que $\operatorname{sim}$ e $117(79,1 \%)$ responderam que não.

A prevalència de mães que querem ter filhos è de $22,1 \%$, calculando-se o intervalo de confiança exato de $95 \%$ para prevalència obtivemos

$$
\text { IC } 95 \%(15,4 \%-30,2 \%) \text {. }
$$

No entanto, cruzando a variável "pensa em ter filhos" com as respostas das mulheres à questão do porquê pensam ou nào em ter filhos (tabela 19), vè-se que muitas mulheres que responderam não pensar. expressaram o desejo da maternidade, frusto, porém, pela presença da infecção pelo HIV

\section{TABELA 19}

Número e porcentagem de mulheres segundo a variável "pensa em ter filhos" e os motivos alegados do porquê pensam ou não em ter filhos. CRT-DST/AIDS, 1997.

\begin{tabular}{|c|c|c|c|c|}
\hline \multirow{2}{*}{$\begin{array}{l}\text { Motivos pelos quais pensam ou } \\
\text { não em ter filhos }\end{array}$} & \multicolumn{4}{|c|}{ Pensa em ter filhos } \\
\hline & $\mathrm{N}^{\circ} \operatorname{sim}$ & $\% \operatorname{sim}$ & $\mathrm{N}^{\circ}$ não & \% nào \\
\hline Já tenho o suficiente & - & - & 7 & 6,0 \\
\hline Estou esterilizada & 1 & 3,2 & 25 & 21,4 \\
\hline Passei da idade & 1 & 3,2 & 7 & 6,0 \\
\hline $\begin{array}{l}\text { Queria. mas tenho medo do bebè } \\
\text { nascer positivo }\end{array}$ & 8 & 25,8 & 50 & 42,7 \\
\hline Grávida & 2 & 6,5 & 4 & 3,4 \\
\hline Medo de piorar estado saude & - & - & 4 & 3,4 \\
\hline Mais sofrimento & - & - & 2 & 1,7 \\
\hline Penso, se ficar muito bem ou curar & 7 & 22,6 & 1 & 0,8 \\
\hline Desejo de toda mulher & 7 & 22,6 & - & - \\
\hline Melhor adotar & - & - & 2 & 1,7 \\
\hline Não quero Ter filhos & - & - & 3 & 2,6 \\
\hline Outros & 4 & 12,9 & 9 & 7,7 \\
\hline Não respondeu & 1 & 3,2 & 3 & 2,6 \\
\hline TOTAL & 31 & 100,0 & 117 & 100,0 \\
\hline
\end{tabular}


Ressalte-se que das mulheres que referiram nào pensar em ter filhos. aproximadamente metade relacionou motivos ligados ao medo da doença para elas ou para seus conceptos e nào à ausència de desejo de ter filhos.

Observamos, ainda. que as 31 mulheres que expressaram o desejo de engravidar não, necessariamente. pretendiam concretizar a gestaçào. Uma delas tinha sido submetida a laqueadura: outra nào estava mais em idade fértil: 7 associavam o fato de ter filhos a melhora ou cura da doença e 8 queriam, mas temiam muito pela saude de seus bebès

Destas $31.18(58.1 \%$ ) tinham filhos. das quais 2 tinham filhos $\mathrm{HIV+}$, e $13(41,9 \%)$ não tinham filhos. Das 18 mulheres que tinham filhos, $3(16,7 \%)$ não moravam com eles, o que significa que das 31 mulheres. $16(51,6 \%)$ ou não tinham filhos ou os filhos não estavam com elas. Entre as mulheres que referiram não pensar em ter filhos esta porcentagem era de $31.6 \%$.

Muitas das 31 mulheres $(67,7 \%)$ tinham parceiro fixo no momento da entrevista

Em sua maioria expressam o receio de que seus bebês naş̧am HIV positivos e muito medo de não receberem apoio das pessoas que as cercam, incluindo seus médicos. Além disto. elas se sentem estigmatizadas por serem HIV positivas e temem que este preconceito se estenda a seus filhos

Interessante observar que, das 117 mulheres que responderam não à questão "vocè pensa em ter filhos?", $23(19,7 \%)$ referiram não usar método anticonceptivo, $65(55,6 \%)$ referiram o uso de algum metodo anticoncepcional e 29 $(24,7 \%)$ não usavam porque não tinham parceiros sexuais

Com relação à variável "desejo", obtivemos, para as 148 mulheres, os seguintes resultados

- $29(19,6 \%)$ - sim consistente.

- $17(11,5 \%)$ - não inconsistente, entendido como sim.

- $\quad 53(35,8 \%)$ - não inconsistente.

- $1(0,7 \%)$ - sim inconsistente.

- $\quad 48(32,4 \%)$ - não consistente

Agrupando-se as très primeiras categorias teremos 99 mulheres $(66,9 \%)$ que expressaram de alguma forma o desejo de ter filhos. As duas ultimas categorias agrupadas somam $49(33,1 \%)$ mulheres que nào querem ter filhos.

Estes resultados mostram coerència com os observados na tabela 19 
Utilizando-se o teste do $\chi^{2}$ aceitamos como significantes todas as associações com $p<0.05$. Assim. não encontramos associação entre pensar em ter filhos e as seguintes variáveis: importància da religião, raça. escolaridade. emprego, renda. ter filhos $\mathrm{HIV+}$, estado conjugal, situação sorológica do parceiro. uso de proteçào nas relaçòes sexuais. métodos anticoncepcionais utilizados antes e depois do diagnóstico do HIV, ter tido abortos espontâneos ou provocados, pensar muito no fato de ser HIV + e. ter decidido o que fazer, no caso de faltar aos filhos (Quadro 1)

Existe associação entre pensar em ter filhos e: idade, ter filhos, número de filhos vivos. morar com filho e, ter motivação para lutar pela vida.

Para medir a associação de pensar em ter filhos com o número de filhos vivos. utilizamos o teste t-Studant para diferença de 2 médias. A média de filhos. das mulheres que pensavam em tê-los, foi de 0,83 filhos e, a média, das que não pensavam, foi 1,70 , portanto, um numero médio maior de filhos $(p=0,003)$

A porcentagem de mulheres que pensam em ter filhos é muito maior entre aquelas com menos de 30 anos, e menor nas mulheres que têm filhos. Nestas, quanto maior o número de filhos vivos e o número de filhos que moram com elas, menor a chance de querer mais filhos. Existe uma associação positiva entre pensar em ter filhos e ter motivação para lutar pela vida.

A variável "desejo" não mostrou associação com: ter filhos HIV+, estado conjugal, situação sorológica do parceiro, uso de proteção nas relações sexuais, uso de contraceptivos antes e depois do diagnóstico da infecção pelo HIV e ter relatado abuso sexual. E, como a variável "pensar em ter filhos", foi associado a: idade, ter filhos. número de filhos vivos e morar com filho (quadro 2). 


\section{QUADRO I}

Numero e porcentagem de mulheres segundo inumeras variaveis e sua relaçào com pensar em ter filhos. CRT-DST/AIDS. 1997

\begin{tabular}{|c|c|c|c|c|c|c|c|c|}
\hline \multirow[t]{3}{*}{ Variavel } & \multirow[t]{3}{*}{ Categoria } & \multicolumn{6}{|c|}{ Pensa em ter filhos } & \multirow[t]{3}{*}{$P^{*}$} \\
\hline & & \multicolumn{2}{|c|}{ Sim } & \multicolumn{2}{|c|}{ Não } & \multicolumn{2}{|c|}{ Total } & \\
\hline & & $\mathrm{N}^{\circ}$ & $\%$ & $\mathrm{~N}^{\circ}$ & $\%$ & $\mathrm{~N}^{\circ}$ & $\%$ & \\
\hline \multirow[t]{2}{*}{ Idade (anos) } & $<30$ & 18 & 40.0 & 27 & 60.0 & 45 & 100.0 & \\
\hline & $\geq 30$ & 11 & 12.8 & 75 & 87.2 & 86 & 100.0 & 0.0008 \\
\hline \multirow{2}{*}{$\begin{array}{l}\text { Importància da } \\
\text { Religiào }\end{array}$} & Sim & 24 & 22.5 & 83 & 77,5 & 107 & 100.0 & \\
\hline & Não & 5 & 20,9 & 19 & 79,1 & 24 & 100,0 & 0.91 \\
\hline \multirow[t]{3}{*}{ Raça } & Branca & 18 & 22,8 & 61 & 77.2 & 79 & 100,0 & \\
\hline & Negra & 10 & 23,3 & 35 & 76.7 & 45 & 100.0 & \\
\hline & Outras & 1 & 14.3 & 6 & 85.7 & 7 & 100.0 & 0.87 \\
\hline \multirow[t]{2}{*}{ Escolaridade } & $\begin{array}{l}\text { Ate } 1^{\circ} \text { grau } \\
\text { completo }\end{array}$ & 20 & 23,5 & 65 & 76,5 & 85 & 100,0 & \\
\hline & $2^{\circ}$ grau ou mais & 9 & 24,3 & 28 & 75,7 & 37 & 100,0 & 0,89 \\
\hline \multirow[t]{2}{*}{ Emprego } & $\begin{array}{l}\text { Empregada ou } \\
\text { aposentada }\end{array}$ & 12 & 21,8 & 43 & 78,2 & 55 & 100,0 & \\
\hline & Não empregada & 17 & 22,3 & 59 & 77,7 & 76 & 100,0 & 0,88 \\
\hline \multirow[t]{2}{*}{ Renda } & Até $5 \mathrm{SM}$ & 8 & 16,0 & 42 & 84,0 & 50 & 100,0 & \\
\hline & Mais de $5 \mathrm{SM}$ & 16 & 23,8 & 51 & 76,2 & 67 & 100,0 & 0,41 \\
\hline \multirow[t]{2}{*}{ Ter filhos } & Sim & 16 & 16,2 & 83 & 83,8 & 99 & 100,0 & \\
\hline & Não & 13 & 40,6 & 19 & 59,4 & 32 & 100,0 & 0,0079 \\
\hline \multirow[t]{2}{*}{ Morar com filho } & Sim & 13 & 15,9 & 69 & 84,1 & 82 & 100.0 & \\
\hline & Não & 16 & 32,6 & 33 & 67.4 & 49 & 100,0 & 0,043 \\
\hline \multirow[t]{2}{*}{ Ter filho $\mathrm{HIV+}$} & Sim & 2 & 14,3 & 12 & 85,7 & 14 & 100,0 & \\
\hline & Não & 14 & 16,7 & 70 & 83,3 & 84 & 100,0 & $1,0 * *$ \\
\hline Número de & Até um & 67 & 81,7 & 15 & 18,3 & 82 & 100,0 & \\
\hline Filhos vivos & Mais de um & 32 & 48,5 & 34 & 51,5 & 66 & 100,0 & 0,00004 \\
\hline \multirow[t]{2}{*}{ Estado Marital } & Com parceiro & 19 & 27,1 & 51 & 72,9 & 70 & 100,0 & \\
\hline & Sem parceiro & 10 & 16,7 & 50 & 83,3 & 60 & 100,0 & 0,22 \\
\hline
\end{tabular}

$\mathrm{P}^{*}$ : nivel descritivo do teste de associaçao pelo qui-quadrado com correçào de Yates.

P**: Teste Evato de Fisher 


\section{QUADRO 1: (continuaçào)}

Número e porcentagem de mulheres segundo inumeras variaveis e sua relação com pensar em ter filhos. CRT-DST/AIDS. 1997

\begin{tabular}{|c|c|c|c|c|c|c|c|c|}
\hline \multirow[t]{3}{*}{ Variável } & \multirow[t]{3}{*}{ Categoria } & \multicolumn{6}{|c|}{ Pensa em ter filhos } & \multirow[t]{3}{*}{ p* } \\
\hline & & \multicolumn{2}{|c|}{ Sim } & \multicolumn{2}{|c|}{ Não } & \multicolumn{2}{|c|}{ Total } & \\
\hline & & $N^{\circ}$ & $\%$ & $\mathrm{~N}^{\circ}$ & $\%$ & $\mathrm{~N}^{\circ}$ & $\%$ & \\
\hline Sorologia do & Positivo & 8 & 27,6 & 21 & 72.4 & 29 & 100,0 & \\
\hline Parceiro & Negativo & 7 & 27,0 & 19 & 73.0 & 26 & 100,0 & 0,58 \\
\hline Proteção nas & Sim & 12 & 27,9 & 31 & 72,1 & 43 & 100,0 & \\
\hline Relações & Não & 5 & 33,3 & 10 & 66,7 & 15 & 100,0 & 0,94 \\
\hline Contracepção- & Eficiente & 18 & 25,0 & 54 & 75,0 & 72 & 100,0 & \\
\hline Antes do HIV & Não eficiente & 4 & 40,0 & 6 & 60,0 & 10 & 100,0 & $0,24^{* *}$ \\
\hline Contracepção- & Eficiente & 4 & 23,5 & 13 & 76,5 & 17 & 100,0 & \\
\hline Depois do HIV & Não eficiente & 18 & 29,0 & 44 & 71,0 & 62 & 100,0 & $0,76^{* *}$ \\
\hline Aborto & Sim & 5 & 14,7 & 29 & 85,3 & 34 & 100,0 & \\
\hline Espontâneo & Não & 23 & 24,3 & 72 & 75,7 & 95 & 100,0 & 0,36 \\
\hline Aborto & Sim & 9 & 22,5 & 31 & 77,5 & 40 & 100,0 & \\
\hline Provocado & Não & 20 & 22,2 & 70 & 77,8 & 90 & 100,0 & 0,84 \\
\hline Pensa muito no & Sim & 20 & 24,0 & 63 & 76,0 & 83 & 100,0 & \\
\hline HIV & Não & 9 & 18,7 & 39 & 81,3 & 48 & 100,0 & 0,62 \\
\hline Motivação para & Sim & 12 & 15,4 & 66 & 84,6 & 78 & 100,0 & \\
\hline Lutar & Não & 17 & 32,0 & 36 & 68,0 & 53 & 100,0 & 0,040 \\
\hline $\begin{array}{l}\text { Sabe o que fazer } \\
\text { com os filhos }\end{array}$ & Sim & 12 & 16,4 & 61 & 83,6 & 73 & 100,0 & \\
\hline Se ela faltar & Não & 4 & 23,5 & 13 & 76,5 & 17 & 100,0 & $0,49^{* *}$ \\
\hline
\end{tabular}

$\mathrm{P}^{*}$ : nivel descritivo do teste de associaçào pelo qui-quadrado com correçào de Yates.

$P^{* *}$ : Teste Exato de Fisher 


\section{QLADRO 2}

Número e porcentagem de mulheres segundo algumas variaveis e sua relaçào com o "desejo" de ter filhos. CRT-DST/AIDS. 1997

\begin{tabular}{|c|c|c|c|c|c|c|c|c|}
\hline \multirow[t]{3}{*}{ Variavel } & \multirow[t]{3}{*}{ Categoria } & \multicolumn{6}{|c|}{ Desejo de ter filhos } & \multirow[t]{3}{*}{$\mathrm{p}^{*}$} \\
\hline & & \multicolumn{2}{|c|}{$\operatorname{Sim}$} & \multicolumn{2}{|c|}{ Vão } & \multicolumn{2}{|c|}{ Total } & \\
\hline & & $\mathrm{N}^{\circ}$ & $\%$ & $\mathrm{~N}^{\circ}$ & $\%$ & $\mathrm{~N}^{\circ}$ & $\%$ & \\
\hline \multirow[t]{2}{*}{ Idade (anos) } & $<30$ & 44 & 84,6 & 8 & 15,4 & 52 & 100,0 & \\
\hline & $\geq 30$ & 55 & 57,3 & 41 & 42,7 & 96 & 100,0 & 0,001 \\
\hline Sorologia do & Positivo & 20 & 66,6 & 10 & 33,4 & 30 & 100,0 & \\
\hline Parceiro & Negativo & 21 & 70.0 & 9 & 30,0 & 30 & 100,0 & 1,0 \\
\hline Proteção nas & Sim & 11 & 68,7 & 5 & 31,3 & 16 & 100,0 & \\
\hline Relações & Não & 36 & 73,4 & 13 & 26,6 & 49 & 100,0 & $0,75^{* *}$ \\
\hline Contracepção- & Eficiente & 56 & 63,6 & 32 & 36,4 & 88 & 100,0 & \\
\hline Antes do HIV & Não eficiente & 7 & 70,0 & 3 & 30,0 & 10 & 100,0 & $1,0^{* *}$ \\
\hline Contracepçào- & Eficiente & 15 & 62,5 & 9 & 37,5 & 24 & 100,0 & \\
\hline Depois do HIV & Não eficiente & 62 & 82,6 & 13 & 17,3 & 75 & 100,0 & 0,074 \\
\hline Sofreu & Sim & 20 & 62,5 & 12 & 37,5 & 32 & 100,0 & \\
\hline Abuso sexual & Não & 79 & 65,5 & 37 & 34,5 & 116 & 100,0 & 0,70 \\
\hline \multirow[t]{2}{*}{ Ter filhos } & Sim & 70 & 62,0 & 43 & 38,0 & 113 & 100,0 & \\
\hline & Não & 29 & 82,8 & 6 & 17,2 & 35 & 100,0 & 0,036 \\
\hline \multirow[t]{2}{*}{ Filho HIV } & Sim & 9 & 60,0 & 6 & 40,0 & 15 & 100,0 & \\
\hline & Não & 90 & 67,6 & 43 & 32,3 & 133 & 100,0 & $0,57^{* *}$ \\
\hline \multirow[t]{2}{*}{ Morar com filho } & Sim & 57 & 60,0 & 38 & 40.0 & 95 & 100,0 & \\
\hline & Não & 42 & 79,2 & 11 & 20,8 & 53 & 100,0 & 0,027 \\
\hline \multirow[t]{2}{*}{ Estado marital } & Sim & 56 & 72,7 & 21 & 27,3 & 77 & 100,0 & \\
\hline & Não & 43 & 60,5 & 28 & 39,5 & 71 & 100,0 & 0,16 \\
\hline Número de & Até dois & 16 & 25,0 & 59 & 75,0 & 75 & 100,0 & \\
\hline Filhos vivos & Mais de dois & 0 & 0,0 & 24 & 100,0 & 24 & 100,0 & $0,01 * *$ \\
\hline
\end{tabular}

$\mathrm{P}^{*}$ : nivel descritivo do teste de associação pelo qui-quadrado com correção de Yates. P**: Teste Exato de Fisher 


\subsection{Estímulo para viver e possibilidade de faltar aos filhos}

Com relação aos motivos que as mantêm lutando, 65 mulheres $(43,9 \%)$ referiram serem os seus filhos: $38(25,7 \%)$ referiram a vontade de viver; 16 $(10,8 \%)$ referiram a fé em Deus. outras referiram o apoio da familia e dos amigos e. em menor proporção, o trabalho, o medo de morrer e vários motivos interligados. Apenas 4 das 148 mulheres( $2.7 \%$ ) referiram não ter vontade de lutar

Quanto à possibilidade de faltar aos filhos, 62 mulheres $(55,8 \%$ das 111 respostas válidas) decidiram deixa-los com os avós, tias, padrinhos e o pai; 29 $(26,1 \%)$ não pensaram ou não decidiram o que fazer; $4(3,6 \%)$ já deram a guarda da criança e $2(1,8 \%)$ não têm com quem deixar. Existem, ainda, aquelas que já têm filhos autônomos, que não pensaram na possibilidade de faltarem aos filhos e que. além destes. apresentaram outros motivos diversos. 


\section{DISCUSSÃO}

Considerando as 148 mulheres entrevistadas, poucas delas representavam o padrão típico de risco para a AIDS que o imaginário social construiu; 15 delas teve um único parceiro sexual na vida e mais da metade delas teve ate quatro parceiros.

A distribuição da escolaridade é semelhante à encontrada para a população feminina do Municipio de São Paulo. Observamos, entretanto, que apesar de a maioria das mulheres apresentar baixa escolaridade, a proporção de analfabetas neste estudo é bem menor. e a de mulheres com segundo grau e universitárias discretamente maior do que as mesmas proporções no Municipio (49)

Isto nos remete à questão, levantada quando estudamos o perfil da epidemia de AIDS no Estado de São Paulo, de que devemos ser cuidadosos para que o discurso da pauperizaçào da epidemia não leve às mulheres com maior escolaridade e melhor nivel sócio-econômico uma falsa sensação de "proteção" e distanciamento da doença

Somente $2 \%$ das mulheres foram trabalhadoras do sexo ou trabalharam em clubes noturnos, o que também contradiz o perfil tido como de risco para as mulheres no imaginário social do Brasil.

A proporção de solteiras e separadas foi a mesma em nossa amostra da encontrada para as mulheres do Brasil como um todo. Entretanto a proporção de viúvas é muito maior e, a de mulheres casadas, é menor em nossa amostra com relação à população feminina brasileira (16). Esta diferença não foi inesperada, dado que grande parte destas viủvas tinham um parceiro falecido por AIDS.

A média da idade da primeira relação sexual foi, neste estudo, dois anos mais cedo do que a média das mulheres brasileiras, em geral (16).

A atividade sexual é uma questão muito importante, e está, muito freqüentemente, relacionada ao amor e à afetividade e não somente à questão da procriação(99). Estes sentimentos românticos se contrapõem, na prática, às medidas preconizadas para a prevenção das DST/AIDS. 
O preservativo não e uma coisa fäcil de ser introduzida nas relaçōes entre homens e mulheres. Há grandes dificuldades de negociação para o seu uso de uma forma geral e. especialmente. para seu uso constante nas relações que se estendem durante um longo tempo (9)

Solicitar o uso de preservativos pelo parceiro implica em assumir diversos riscos que vão desde as questões mais ligadas à afetividade, como a quebra de confiança entre o casal, passando pelas questões culturais que não vêem com bons olhos as mulheres que demonstram conhecimento e iniciativa na esfera sexual, até nos casos em que existe dependència econòmica da mulher com relação ao seu parceiro, risco de perder o apoio financeiro do companheiro $(14,46,102)$.

Como coloca PAIVA(1996): "Por mais que se trabalhe o preconceito, falar de AIDS é trazer algo muito dificil entre um homem e uma mulher, não se quebra rapidamente este tom de acusação construido durante uma década em relação à AIDS, associado ao estigma histórico das doenças transmitidas sexualmente"- (71$\operatorname{pg} 276)$.

Em nosso estudo, o fato de algumas mulheres se perceberem sob risco não se constituiu em estímulo suficiente, para que tivessem alguma ação concreta no sentido de evitar a propria infecção. Discutir AIDS, uso de preservativo e relações extraconjugais é muito dificil em uma sociedade onde teoricamente todos são monogâmicos.

Como vimos, mesmo a preocupação das mulheres já infectadas pelo HIV com a possibilidade de reinfecção e consequente aumento da carga viral, não redundou no uso consistente de preservativos.

Parece menos dificil propor o uso de preservativo nas relações eventuais, onde os vinculos são menos estreitos. Mulheres com parceiros fixos, entretanto, sentem que é muito dificil usar preservativos em todas as relações sexuais. As razões são as mesmas que se ouve sempre e que se conhecem de diversos estudos: a maioria dos parceiros não gosta de usar preservativos e prefere não fazê-lo $(62,71)$.

Neste sentido precisamos promover discussões de outras formas de prevenção, além do preservativo masculino, em todos os espaços possíveis. $\dot{\mathrm{E}}$ fundamental, para diminuir, concretamente, a vulnerabilidade das mulheres, estimular a pesquisa e a produção a baixo custo de métodos anticoncepcionais e de proteção para o HIV que possam ser controlados por elas, como os cremes 
espermicidas(7). E. importantissimo. que se encontre uma substància que. além de apresentar uma efetiva atividade bactericida e virucida in viro, nào provoque irritabilidade da parede vaginal, que pode levar a microlesões. aumentando, assim. a suscetibilidade desta parede a entrada de microorganismos

E, sobretudo, ter coragem de flexibilizar a discussão.

Discutir a possibilidade de acordos entre casais estáveis, nos quais ambos fazem o teste anti-HIV, com alguma periodicidade e, se negativos, tem relações sexuais sem preservativos, comprometendo-se a usá-los nas relações extra-casal. Obviamente. temos ai um risco implicito, de que um dos componentes do casal possa não cumprir o acordo. Não podemos negar, entretanto, que se aplicada para um grande número de casais, esta conduta poderia levar, além de uma maior conscientização das pessoas comprometidas nestes acordos, a identificação de alguns pares discordantes, que, com a falta de diálogo, não se identificam e permanecem mantendo relações sexuais desprotegidas.

Discutir a possibilidade do uso do preservativo feminino, como alternativa ao masculino. Abrir a possibilidade de relações sem penetração como uma medida de prevenção da infecção pelo HIV.

Não podemos dizer, simplesmente, que se deve usar preservativos nas relações sexuais anais, vaginais e orais, sem explicitar que, embora exista possibilidade de infecção pelo HIV em todas elas, a sua probabilidade de ocorrência é muito diferente nos diversos tipos de relações sexuais

Orientar, claramente, quanto ao fato de que, no periodo menstrual e na presença de lesões genitais o risco para aquisição de qualquer doença sexualmente transmissivel fica aumentado.

Enfim, deixar claro, sempre, as possibilidades de proteção e de risco em cada situação e método.

Só não podemos nos deixar imobilizar pelo discurso pronto e fechado, que as pessoas já decoraram mas, não conseguem praticar. Embora não possamos deixar de envidar esforços, no sentido de expandir o método de prevenção sabidamente mais seguro, o uso de preservativos em todas as relações sexuais, devemos considerar a questão da hierarquia de risco e que, do ponto de vista da saúde pública, alguma proteção é melhor do que nenhuma (7). 
Interessante observar que os homens tambem se expõem a riscos. Cerca de um quinto dos parceiros. não infectados pelo HIV. não fazem uso consistente de preservativos, mesmo sendo cientes da condiçào sorológica de suas parceiras

Há que se considerar. tambem, que a imprensa e mesmo alguns técnicos da saude não facilitaram a percepçào de risco da população heterossexual, particularmente a masculina. e incultiram a idéia de que "homem não pega aids de mulher" ou que "é muito dificil um homem ser infectado pelo HIV por uma mulher".

Vários estudos tèm investigado a probabilidade de transmissão do HIV nas relaçôes heterossexuais(77), e seus resultados indicam quase sempre que a possibilidade de transmissão homem-mulher é maior do que a transmissão mulherhomem. $\mathrm{O}$ que tem variado muito nestes estudos é o quanto esta possibilidade é maior. Um estudo Europeu envolvendo 525 pares discordantes, 378 casais onde o homem era o caso indice e, 148 casais onde o caso índice era a mulher, concluiu que a infectividade era maior do homem para a mulher, mas não significativamente (31)

Apesar de apontar diversos fatores biológicos. como a maior quantidade de CD4 no líquido espermático do que no líquido vaginal e, consequentemente, maior carga viral no esperma, quando o homem está infectado pelo HIV; liberação de maior quantidade de secreção sexual masculina $(5$ a $7 \mathrm{ml}$ ) do que feminina ( 1 a 3 ml) nas relações sexuais; ectopia cervical; uso de contraceptivos orais; presença de outra DST; alta prevalência de vulvovaginites e outros. como fatores explicativos da maior chance de infecção pelo HIV das mulheres pelos homens do que o contrário(81), não podemos subestimar a forte associação das relações de gênero nas sociedades com a maior vulnerabilidade das mulheres à infecção pelo $\operatorname{HIV}(35,98)$.

Remetendo-nos novamente ao perfil dos casos notificados de AIDS no Estado de São Paulo, podemos, facilmente destacar alguns fatores que indicam uma maior vulnerabilidade das mulheres: - o fato de elas terem menor escolaridade, entendido como condição sócio-econômica menos privilegiada e, uma maior proporção, entre os homens heterossexuais, de multiplicidade de parceiras e, ainda, uma maior proporção de mulheres, que apresentam como categoria de exposição para o HIV, o fato de seus parceiros terem múltiplas parceiras sexuais. Reiterando o fato de que, apesar da idealização das relações monogàmicas, por diversas questões sócio-culturais, a prática de multiplicidade de parceiros é mais freqüente e mais aceitável socialmente nos homens do que nas mulheres. embora este fato raramente seja explicitado entre os casais 
Vale ressaltar que. a orientação de diminuir o numero de parceiros ou permanecer em monogamia. enquanto forma de prevenção das DST/AIDS. não e de muita valia para as mulheres. Lembramos. mais uma vez que, mais da metade das mulheres desta pesquisa teve até 4 parceiros na vida. e que $15 \%$ delas teve um único parceiro. Além de que, a maioria delas se contaminou em relações monogâmicas. Ressaltamos ainda, que. segundo dados da Vigilância Epidemiológica de DST/AIDS do Estado de São Paulo. mais de 50\%, das mulheres notificadas com AIDS, com categoria de exposição heterossexual, referiram parceria sexual única no momento do diagnóstico.

Além da dificuldade de diálogo, a percepção de risco destas mulheres é muito pequena, até mesmo para as que se encaixam nos chamados grupos de risco, como colocaram algumas entrevistadas:

"Nunca imaginei. naquela época não sabia nem o que era AIDS, não via televisão, não lia jornal. Era desligada... Mesmo com o marido HIV+ não suspeitava que teria AIDS. Não imaginei porque ele usava droga e achei que AIDS pegava só pelo uso de drogas, mas como eu não tomava, nunca usei droga, eu achava que não podia ter"

"Soube há 3 anos. estava grávida. Achava que não tinha porque não era "homem sexual" e estava fora, depois descobri que o câncer gay dava em mulher também." (ela era parceira de um UDI)

"Eu usava drogas e quis mostrar para o meu marido atual que eu não era HIV+, pedi para a gineco pedir o teste. dai deu positivo. Aí caiu o mundo."

"Como a maioria das pessoas nunca pensei que pudesse acontecer comigo, só fiquei sabendo quando meu marido adoeceu." (ela era parceira de um UDI)

“Eu casei virgem, tenho até vergonha de falar isto...minha filha tinha 11 meses e estava amamentando quando descobri que ele tinha AIDS. A gente via televisão e anúncios de AIDS e eu falava para ele: já pensou estar namorando agora com estas coisas para se preocupar." (parceiro bissexual) 
Analisando. neste estudo. as respostas a pergunta: vocè ja tinha pensado que podia ser $\mathrm{HIV}+$, antes de fazer o teste? Vimos que 70 mulheres responderam sim. A primeira vista parece ser um indicador de que quase metade das mulheres tinha percepção do seu risco para adquirir a infecção pelo HIV. Mas atentando para os motivos alegados por elas. temos que a maioria só pensou na possibilidade de infecçào pelo HIV pelo adoecimento dos maridos, filhos ou delas mesmas.

Uma vez colocadas diante da irreversibilidade da infecção pelo HIV estas mulheres se encontram com um dilema. ainda maior do que o das mulheres em geral. que é o de viver sua afetividade e sexualidade frente a este novo quadro e ainda dar conta das questões reprodutivas.

É interessante observar que o aconselhamento para o planejamento familiar das mulheres HIV positivas, ainda não é uma ação sistemática (ou prevista) na maioria dos programas de AIDS no Brasil. Mesmo serviços considerados de boa qualidade de atendimento ainda não atentaram para esta questão de gênero de fundamental importància.

E, sabendo-se que a maioria destas mulheres está em idade fértil e que o desejo de ter filhos é algo culturalmente cultivado no gènero feminino, a estruturação de serviços, técnica e humanamente preparados para o aconselhamento sobre anticoncepção e planejamento familiar seria fundamental $(21,54,55,103)$.

Mesmo com o uso apropriado de AZT na gestação e a possibilidade de reduzir, assim, a transmissão materno-infantil para $2 \%$ a $8 \%$, a discussão sobre os direitos reprodutivos das mulheres com HIV/AIDS ainda é bastante controversa e passa por diversas instàncias, desde questões de fórum intimo dos profissionais que lidam com estas mulheres até a inexistência de serviços tecnicamente preparados para recebê-las

Um claro exemplo disto é que, algumas mulheres, nas questões abertas e nos grupos, referiram ser informadas pelos seus médicos dos métodos anticonceptivos mais apropriados ao uso, pelo fato de serem HIV+, mas a quase totalidade delas referiu não ter tido orientações sobre as questões relativas ao planejamento familiar e estavam mal informadas sobre reprodução e a probabilidade de infecção pelo HIV para seus conceptos, com e sem o uso de AZT e outras drogas anti-retrovirais, ou qual a melhor forma de engravidar diminuindo o risco do bebê se infectar, de reinfecção da mãe e de infecção ou reinfecção do parceiro 
E, alem disto. sabe-se que a infecção pelo HIV. se não diminui a fertilidade. diminui as chances da gravidez chegar a termo. interferindo negativamente na evolução desta $(91,92)$.

Entretanto, a imensa maioria dos serviços de tratamento de infertilidade. em todo o mundo. consideram a infecção pelo HIV, na mulher. como criterio de exclusão para tratamento (37.61), mesmo sabendo que. com o uso do AZT a taxa de infecçào do feto pode ser reduzida até atingir apenas $2 \%$. Interessante os questionamentos: Por que mulheres com outras patologias graves, como por exemplo diabetes juvenil, não são automaticamente excluidas destes serviços? Por que os serviços de infertilidade não orientam, às mulheres HIV positivas, sobre a possibilidade de realizar inseminação artificial como uma opção segura de engravidar sem riscos para os parceiros soronegativos?

Temos aqui, sem sombra de dúvida. uma influència do preconceito a que os portadores do HIV são submetidos. pelos diversos segmentos da sociedade, inclusive o setor da saúde.

Os profissionais de saúde parecem ter medo de que, abrindo a discussão sobre prevenção e anticoncepção, as pessoas se sintam respaldadas para tomar posturas com relação ao planejamento familiar, das quais estes profissionais, geralmente, discordam, calcados em suas concepções técnicas e em seus próprios principios morais e éticos. Preferem, assim, manter uma postura hermética e autoritária, como se isto fosse suficiente para que todos os usuários dos serviços seguissem à risca suas orientações de prevenção e anticoncepção.

No Brasil, na verdade, não há empecilho legal para uma mulher HIV positiva ter filhos. O teste anti-HIV sequer é compulsório por muitas razões, inclusive por questões éticas. Entretanto, no Estado de São Paulo, em 1999, foi estabelecida uma lei que torna obrigatório o oferecimento do teste anti-HIV a todas as mulheres grávidas nos serviços de pré-natal e a possibilidade de realização do mesmo(59), com o consentimento da gestante. Teoricamente todas as mulheres grávidas têm acesso ao AZT, se seu teste resultar positivo. Na prática, contudo, isto nem sempre acontece.

É preciso considerar, ainda, que, mesmo quando o AZT é oferecido as mulheres, nem sempre elas aderem ao seu uso, na gestação(89). 
Faz-se urgente o entendimento de como preparar os profissionais e os serviços para a discussão de formas de atenção. mais adequadas. a resolução desta questão primordial para mulheres HIV positivas

Como prepara-las para tomar decisòes reprodutivas conscientes?

$\mathrm{O}$ que se vè é muita ambigüidade no que diz respeito ao desejo de ter filhos pelo medo e/ou sensação de culpa diante da possibilidade da criança nascer $\mathrm{HIV+}$. Uma das mulheres entrevistadas expressou esta ambigüidade de forma contundente. quando questionada se concordava com a critica que os outros fazem à mulheres HIV+ que desejam ter filhos:

“ O HIV não tira o direito da mulher ser mãe. mas é uma irresponsabilidade. A gente não tem direito de pôr uma pessoa com isto no mundo Mas e a gente. como fica? O amor que a gente tem para dar, os nossos sonhos, como ficam? E muito complicado. o que mais dó no HIV é a impotência. Eu me arriscaria a ter um filho. mas tenho medo."

Esta ambiguidade se reflete também no que diz respeito ao uso de métodos anticonceptivos. Tanto as mulheres que pensam em ter filhos quanto as que não pensam usam. na sua maioria, o condom com esta finalidade. Poucas se preocupam com a questão da proteção dupla, e quase todas receberam de seus médicos a orientação de usar condom, sem discutirem a efetividade do método enquanto anticonceptivo. Sabendo-se que está muito aquém de 100\% (95) para ser usado enquanto metodo unico em mulheres, para quem engravidar pode representar uma tragédia.

A proteção dupla pode evitar tanto a gravidez como a transmissão ou reinfecção do HIV e também de outras DST. Além disto, serve de proteção tanto para a mulher quanto para seu parceiro.

Com relação ao desejo de ter filhos, os achados deste estudo são condizentes com outros da literatura. Os testes de associação mostraram que o desejo de ter filhos não. necessariamente. obedece ao que parece racional ao senso comum

Assim, fatos como: o parceiro ser HIV+, a mulher ter tido filhos $\mathrm{HIV}+\mathrm{e}$ abortos, ter parceiro fixo, e também raça, escolaridade, renda familiar, percepção de risco, uso de proteção nas relações sexuais e dos diferentes métodos anticonceptivos nào mostraram, ao contrário do que a lógica poderia sugerir, associaçào significante com o "desejo de ter filhos" ou com "pensar em ter filhos" 
Ter filhos. um maior numero de filhos e ter filhos morando com elas sào fatores que influenciam negativamente o desejo de ter mais filhos. Parece natural a relação das mulheres mais jovens e um maior desejo de ter filhos, ate porque. via de regra. as mulheres mais velhas ja tiveram seus filhos. o que interfere, decisivamente. neste desejo. Os filhos constituem, na maioria das vezes. um estimulo para lutar pela vida

Em uma pesquisa realizada com uma amostra de mulheres da população geral (16), investigou-se também, o desejo de ter filhos e a demanda por anticoncepção. Nessas, como nas mulheres da nossa pesquisa. o desejo de ter filhos diminui com o aumento da idade, com o número de filhos e com o número de filhos vivos. Duas de cada très mulheres sem filhos, desejam ter filhos, entre aquelas com um filho, a proporção é de uma em cada duas mulheres, e se reduz em uma para cada dez. para as mulheres que já tem dois filhos. Nesta pesquisa o percentual de mulheres que não querem ter filhos é maior quanto mais alta a escolaridade. Nessas mulheres se observa, também, a não utilização de métodos anticoncepcionais, mesmo diante da falta de desejo de ter mais filhos, este fato é mais freqüente nas mulheres em uniões estáveis. O percentual de filhos indesejados aumenta com a idade da mãe e com o número de filhos tidos, indicando a alta frequência de gestações sem planejamento

Em dois estudos conduzidos nos EUA, com 403 e 1921 mulheres HIV positivas, respectivamente $(1,15)$, foram obtidos resultados semelhantes aos nossos, não tendo sido encontrada associação da decisão de ter filhos nem com percepção de risco, nem com uso de anticoncepcionais, mas existe a associação com ter filhos e ter filhos vivendo com elas. Diferentemente do nosso estudo, eles encontraram associação das decisões de ter filhos com a raça e com o fato de ter parceiro fixo. Num destes estudos, embora não houvesse associação entre escolaridade e decisão de ter filhos, a escolaridade interferia positivamente no fato da gestação chegar a termo. 


\section{CONCLUSÃO}

Concluimos que a infeç̧ão pelo HIV não modifica. substancialmente. o fato de querer ter filhos. Embora apareça, para muitas mulheres. teoricamente. como um motivo para coibir a maternidade

Nas mulheres HIV positivas a intenção de ter filhos não signnifica. necessariamente, planejamento do melhor momento clínico e pessoal para realizar a gestação. Assim como, a intenção de não tè-los, não se traduz, na prática, na adoção de métodos anticonceptivos seguros o suficiente para evitar consistentemente uma gestação, pelo menos teoricamente, indesejada, assim como acontece para muitas mulheres da população em geral.

Enquanto os serviços de saúde se perdem em considerações éticas e filosóficas e, os profissionais mantèm uma postura hermetica e autoritária, não respondem à demanda destas mulheres que continuam usando métodos contraceptivos inadequados, tendo gestações indesejadas e não tendo a melhor evolução possível, para si e seu concepto, nas gestações desejadas.

Independente dos conflitos morais a que os profissionais de saúde estão submetidos(2), as mulheres HIV positivas têm direito a uma decisão consciente sobre que métodos anticonceptivos usar e sobre ter ou não ter filhos, e devem fazê-lo o mais informadas possivel quanto à perspectiva de contaminação, ou não, de seus bebês e parceiros soronegativos no momento da concepção.

É urgente e importantíssimo buscarmos novas formas de prevenção do HIV condizentes com as necessidades físicas e psicológicas das mulheres $(29,30,46,48)$, considerando-se, entretanto, que a participação masculina é primordial neste processo(3). Se não considerarmos as expectativas de ambos os gêneros, no que diz respeito à sexualidade e reprodução, será muito dificil conseguirmos implantar e/ou implementar, na prática, quaisquer formas de prevenção.

Sendo asssim, urge preparar os serviços de saude para o atendimento e orientação das mulheres HIV positivas ou parceiras de homens HIV positivos. São necessários serviços que promovam um ambiente de suporte para estas mulheres e seus parceiros(86), propiciando às pessoas vivendo com HIV/AIDS condições de realizar opções no que concerne a sexualidade e às decisões reprodutivas 
REFERÊNCIAS BIBLIOGRÁFICAS 


\section{REFERÊNCIAS BIBLIOGRÁFICAS}

1 Ahluwalia IB. DeVellis RF, Thomas JC. Reproductive decisions of women at risk for acquiring HIV infection. AIDS Education and Prevention. 1998, $10(1), p 90-97$

2 Araujo NJSM AIDS e preconceito. São Paulo. 1992. [Dissertação de mestrado Pontificia Universidade Católica de São Paulo]

3 Arilha M. Homens, Saúde Reprodutiva e Gênero: o desafio da inclusão. In: Giffin K. Costa SH(Orgs) - Questões de Saúde Reprodutiva. Rio de Janeiro: Editora FIOCRUZ, 1999.

4 Ayres JRCM, França Jr. I, Calazans GJ. AIDS, Vulnerabilidade e Prevenção. In: Anais do II Seminário Saúde Reprodutiva em Tempos de AIDS. Rio de Janeiro: ABIA/IMS-UERJ; 1997. p20-37.

5 Badiani R, Quental I, Santos EM. DST/AIDS e a Pesquisa Nacional sobre Demografia e Saúde: Uma análise do nível de conhecimento e comportamentos de vulnerabilização. Relatório de pesquisa - BENFAM e DHS. Rio de Janeiro; 1997.

6 Barbosa MAR, Favero JCF, Grilo NAG, Silva GMS, Fonseca EMG, Negreiros RSN, Quadros RG. Assessment of the programme os serological assistence to pregnant women (PASG) and the programme of assistance to seropositive pregnant women $(\mathrm{PGA}+)$ in the city of Guaruja, Brazil. 12th World AIDS Conference, Geneva, June28-July3 - 1998, Anais.

7 Barbosa RM. HIV/AIDS, Transmissão heterossexual e métodos de prevenção controlados pelas mulheres. In: Saúde Sexual e Reprodutiva, n' 2. ABIA, 2000, Rio de Janeiro

8 Barbosa RM, Lago TG. AIDS e direitos reprodutivos: para além da transmissão vertical. In: Parker, R. (org). Políticas, instituições e AIDS: enfrentando a epidemia no Brasil. Rio de Janeiro: Jorge Zahar Ed.: ABIA, 1997. pl63-175. 
9 Barbosa RHS AIDS e Saude Reprodutiva: novos desafios. In Giffin K. Costa SH (Orgs) - Questões de Saúde Reprodutiva Rio de Janeiro Editora FIOCRUZ. 1999

10 Barre-Sinoussi F. Montagneir L. Chermann JC. Rey F. Nugyese MT. Isolation of T-lynphotropic retrovirus from a patient at risk for acquired immune deficiency syndrome (AIDS). Science. 1983; 220:868

11 Bastos FI. Barcellos C. Geografia social da AIDS no Brasil Rev. Saúde Pública. 1995, 29(1):52-62.

12 Bastos. FI A feminização da epidemia de Aids no Brasil: Determinantes Estruturais e Alternativas de enfrentamento. In: Saúde Sexual e Reprodutiva, no 3. Rio de Janeiro: ABIA/IMS-UERJ, 2000. (Coleção ABIA)

13 Bastos, FI Ruína e construção: AIDS e drogas injetáveis na cena contemporânea. Rio de Janeiro, Relume-Dumara/ABIA/IMS-UERJ; 1996.(Historia Social da AIDS,6).

14 Bauni E.K. and Jarobi B.O. Family planning and sexual behavior in the era of HIV/AIDS The case of Nakuru District, Kenya. Studies in Family Planning 2000,31(1):69-80

15 Bedimo AL, Bessinger R, Kissinger P. Reproductive choices among HIVpositive women Soc. Sci. Med. 1998, Vol 46. №2, p171-179

I6 BENFAM. Pesquisa Nacional sobre Demografia e Saúde - 1996. Rio de Janeiro; 1997

17 Berer M, Ray S. Mulheres e HIV/AIDS: um livro sobre recursos internacionais. Natividade. AG e Botassi M (tradutoras). São Paulo: Editora Brasiliense, 1997

18 Bower JE: Kemeny ME; Taylor SE; Fahey JL. Cognitive processing, discovery of meaning, CD4 decline, and Aids related mortality among bereaved HIVseropositive men. J Consult Clin Psychol. 1998; 66(6):979-986 
19 Buchalla C.Y A Sindrome da Imunodeficiência Adquirida a mortalidade masculina, de 20 a 49 anos. no Município de São Paulo:1983 a 1986. São Paulo. 1991 [Doutorado. Faculdade de Saude Pública, USP]

20 Casali Oliveira MC Singularidades do Luto por Aids em Mulheres - As Viúvas da Aids. São Paulo, 2000. [Dissertação de Mestrado - Departamento de Psicologia Clinica da Pontificia Lniversidade Católica deSP]

21 Catz S L. Meredith KL. Mundy LM. Women's HIV transmission risk perceptions and behaviors in the era of potent antiretroviral therapies. AIDS, Education and Prevention, 2001; 13(3): 239-251.

22 Centers for Disease Control and Prevention - CDC - HHS NEWS - U.S. Department of health and human services. Aids Falls from Top Ten Causes of Death: Teen births. Infant Mortality, Homicide All Decline. Atlanta: oct, 1998

23 Centers for Disease Control and Prevention - CDC. HIV and AIDS - United States, 1981-2000. MMWR. June, 2001; (50)n²1:430-433.

24 Centers for Disease Control and Prevention - CDC. The Global HIV and AIDS Epidemic,2001. MMWR. June, 2001; (50):434-439.

25 Centers for Disease Control and Prevention - CDC. First report of AIDS. MMWR . June, 2001; (50): 429 .

26 Centers for Disease Control and Prevention - CDC. Kaposis sarcoma and pneumocistis pneumonia among homossexual male residents of New York city and California. MMWR. May, 1981; (30):305-308.

27 Centers for Disease Control and Prevention - CDC. A group of HIV positive women. MMWR. May, 1999; (48):413-416.

28 Chaisson RE. Impact of opportunistic disease on survival in patients with HIV infection. AIDS; 12(1):29-33, jan 1.

29 Chen, Lincoln C, Amor JS, Segal SJ (Edit). AIDS and Women's Reproductive Health. New York: Plenum Press; 1991. 
30 Correa S. "Saude Reprodutiva". Gènero e Sexualidade legitimação e novas interrogaçòes. In: Giffin K. Costa SH (Orgs) - Questões de Saúde Reprodutiva Rio de Janeiro. Editora FIOCRUZ, 1999

31 Downs AM, Vicenzi I Probability of Heterosexual Transmission of HIV Relationship to the number of unprotected sexual contacts Journal of AIDS and Human Retrovirology. 1996; 11:388-395

32 European Center for the Epidemiological Monitoring of AIDS. HIV/AIDS Surveillance in Europe: Report $n^{\circ}$ 61, 30 June 1999.

33 Fonseca MG, Bastos FI, Derrico M, Andrade CLT, Travassos C, Szwarcwald CL. AIDS e grau de escolaridade no Brasil: evolução temporal de 1986 a 1996 Cad. Saúde Pública, Rio de Janeiro. 2000:16(Supl. 1) 77-87

34 Gallo RC, Popovic M, et al. Frequent detection and isolation of cytopathic retrovirus (HTLV-III)from patientes with AIDS and a risk for AIDS. Science. $1984 ; 224: 500-503$

35 Giffin K. Beyond empowerment: heterosexualities and the prevention of AIDS Soc.Sci. Med. 1998; 46(2):151-156

36 Goldstein,D. Aids and Women in Brazil: the emerging problem, Soc.Sci.Med. 1994; Vol.39, n 7, p 919-929.

37 Gollub E.L. Human rights is a US Problem, too: The case of women and HIV. American Journal of Public Health. 1999; 89: 1479-1482

38 Gottlieb MS, Schroff R, Schanker HM, et al. Pneumocystis Carinii pneumonia and mucosal cadidiasis in previously healthy homossexual men: evidence of a new acquired cellular immunodeficiency. N Engl J Med. 1981; 305: 1425-1431

39 Grangeiro A. O perfil sócio econòmico dos casos de aids da cidade de São Paulo. In: Parker R. et al [Orgs]. A Aids no Brasil. Rio de Janeiro: Relume Dumará. 1994. p91-125.

40 Greco DB. Ética, Saude e Pobreza - As doenças emergentes no seculo XXI Bioética. 1999: 7:189-198 
41 Greco DU. Epidemiological profile of women over age 15 at risk or infected with HIV in Belo Horizonte. Brazil - Jan.-Dec. 1996. 12th World AIDS Conference, Geneva, June28-July3 - 1998, Anais.

42 Green G. Sex. love and seropositivity: balancing the risks. In: Aggleton P., Davies P., Hart G.(eds). AIDS: Safety, Sexuality and Risk. London Taylor \& Francis; 1995.

43 Grillo Diniz S, Mello e Souza C, Portella A. Not like our mothers - reproductive choice and the emergence of citizenship among Brazilian rural workers, domestic workers and housewives. In: Petchesky R, Judd $K$ (eds). Negotiating Reproductive Rights. London: Zed Books; 1998.

44 Guimarães CD Mulheres, Homens e AIDS o visivel e o invisível. In: Parker R. et al [Orgs]. A Aids no Brasil. Rio de Janeiro: Relume - Dumará, 1994. p217230.

45 Hankins C, Gendron S, Tran T et al. Sexuality in Montreal women living with HIV. AIDS Care. 1997; 9(3):261-71.

46 Heise LL, Elias C. Transforming AIDS prevention to meet women's needs: a focus on developing countries. Soc. Sci. Med. 1995, Vol 40. No7, p931-943.

47 Herriques HN. Prevention of AIDS among black women living in slums: A Latin-American experience. 12th World AIDS Conference. Geneva, June28July3 - 1998, Anais.

48 Hunter DJ, Mati JK. Contraception, family planning, and HIV. AIDS and Women's Reproductive Health. Edited by Chen L.C. et al. Plenum Press, New York, 1991

49 IBGE - Instituto Brasileiro de Geografia e Estatistica. Censo Demográfico. 1991

50 Joint United Nations Programme on HIV/AIDS (UNAIDS). AIDS epidemic update: December 2000. Global HIV/AIDS \& STD Surveillance. Geneva: UNAIDS: december. 2000 
51 Joint United Nations Programme on HIV/AIDS (LNAIDS). El primer análises de la epidemia mundial, país por pais. revela inquietantes diferencias com respecto al SIDA. Geneva: UNAIDS; june. 1998

52 Joint United Nations Programme on HIV/AIDS (UNAIDS). Um nuevo informe de las Naciones Unidas para el dia mundial de SIDA; advierte de que la epidemia de VIH es mucho peor de lo que se creía. Paris; november, 1997.

53 Kalichman AO. Pauperização e banalização de uma epidemia. In: Seminário Epidemiologia Social da AIDS, Anais. Rio de Janeiro, 1994, p.20-26.

54 Kass NE. Policy, ethics, and reproductive choice: Pregnancy and childbearing among HIV infected women. Acta Pediatr 1994:(suppl 400):95-98

55 Korn AP, Abercrombie PD. Gynecology and Family Planning care for the women infected with HIV. Obstetrics and Gynecology Clinics of North America. 1997, 24(4):855-871.

56 Lackritz EM. Prevention of HIV transmission by blood transfusion in the developing world: achievements and continuing challenges. AIDS 1998; 12 (Suppl A): S81-86

57 Lei $N^{\circ} 5.190$ de 20 de junho de 1986. Dispõe sobre a realização de testes para deteç̧ào de anticorpos do virus da Sindrome da Deficiència Imunológica Adquirida (AIDS). Pub. D.O.E. de 21/06/86.

58 Lei $\mathrm{N}^{\circ} 7.649$ de 25 de janeiro de 1988. Estabelece a obrigatoriedade de cadastramento dos doadores de sangue, bem como a realização de exames laboratoriais no sangue coletado, visando a previnir a propagação de doenças, e dá outras providências. Pub. D.O.U. de 27/01/88.

59 Lei $N^{\circ} 10.449$ de 20 de dezembro de 1999 Institui a obrigatoriedade do oferecimento às gestantes do teste para deteç̧ão de anticorpos anti-HIV e da sifilis. em todo pre-natal realizado pelos serviços publicos e privados no Estado de São Paulo. Pub. D.O.E. de 21/12/99. 
60 Lira MMTA. Mortalidade Prematura no Município de São Paulo. Anos Potenciais de Vida Perdidos: 1980,1985,1990 e 1995. São Paulo; 1998. [Dissertação de Mestrado - Faculdade de Saúde Pública da USP]

61 Lyerly AD, Anderson J. Human immunodeficiency virus and assisted reproduction: reconsidering evidence, reframing ethics. Fertil Steril. 2001; 75(5):843-58.

62 Loyola MA (organizadora), Giami A [et al] Aids e sexualidade: o ponto de vista das ciências humanas. Rio de Janeiro: Relume-Dumará: UERJ, 1994

63 Mann J, Tarantola DJM, Netter TW. Como avaliar a vulnerabilidade à infecção pelo HIV e AIDS. In: Richard Parker. Jane Galvão, José Stalin Pedrosa (orgs da edição brasileira) - A AIDS no Mundo. Rio de Janeiro: Relumé Dumará: ABIA IMS, UERJ, 1993, 275-300.

64 Martins TA, Queiroz TRB, Broutet N, Evangelista CN, Feitosa IS. Profile of the women with AIDS and the women consulted at STD clinics in Fortaleza, Ceara, Northeast Brazil. 12th World AIDS Conference, Geneva, June28-July3 1998, Anais.

65 Miller K, Rosenfield A. Population and women's reproductive Health: international perspective. Annu. Ver. Public Health. 1996. 17:359-82.

66 Ministerio da Saúde - Coordenação Nacional DST/Aids - Vigilância Epidemiológica. Boletim Epidemiológico de AIDS ano XIV-nº2. Brasilia; abril a junho de 2001

67 Ministério da Saúde - Coordenação Nacional DST/Aids e CEBRAP - Centro Brasileiro de Análise e Planejamento. Comportamento sexual da população brasileira e percepções do HIV /AIDS. Brasilia ; 2000

68 Moatti JP, Souteyrand Y. HIV/AIDS social and behavioural research: past advances and thoughts about the future. Social Science \& Medicine. 2000; $50: 1519-1532$ 
69 Mocroft A. Vella S. Benfield TL et al Changing patterns of mortality across Europe in patients infected with HIV-1. EuroSIDA Study Group Lancet. 1998, 352(9142): 1725-1730

70 Moore JS. Harrison JS, Doll LS. Interventions for Sexually Active, Heterosexual Women in the United States In Ralph J Di Clemente and Join $L$ Peterson(edit). Preventing AIDS: Theories and Methods of Behavioral Interventions. New York: Plenum Press, 1994; p.243-262.

71 Paiva V Fazendo arte com camisinha: A história de um projeto de prevenção da AIDS para jovens. São Paulo, 1996. [Tese de doutorado. Instituto de Psicologia USP].

72 Paiva V Gendered scripts and the sexual scene promoting sexual subjects among Brazilian teenagers. In Parker R, Barbosa RM. Aggleton P (eds) Framing the Sexual Subject: the Politics of Gender, Sexuality and Power. Berkeley: University of California Press (in press).

73 Parker R, Camargo Jr KR. Pobreza e HIV/AIDS: aspectos antropológicos e sociológicos. Cad. Saúde Pública, Rio de Janeiro. 2000, 16(Supl. 1): 89-102.

74 Parker R. A construção da solidariedade: AIDS, sexualidade e politica no Brasil. Rio de Janeiro. Relume-Dumará/ABIA/IMS-UERJ. 1994. Cap. 3. Abaixo do Equador: bissexualidade e AIDS no Brasil. p55-66. (Historia Social da AIDS;3).

75 Parker R. Sexo entre homens: Consciência da AIDS e comportamento Sexual entre os homens homossexuais e bissexuais no Brasil. In: Parker R. et al [Orgs]. A Aids no Brasil. Rio de Janeiro: Relume - Dumará. 1994 p129-149

76 Piot P, Quinn TC, Taelman $H$, Minlangu KB, Wobin O, Mbendi $N$ et al. Acquired immunodeficiency syndrome in a heterossexual population in Zaire. Lancet 1984, July (14):65-69. 
77 Plummer FA. Moses S. Ndinya-Achola JO. Factors affecting female-to-male transmission of HIV-! Implications of transmission dynamics for prevention AIDS and Women's Reproductive Health. Edited by Chen L.C. et al Plenum Press, New York, 1991.

78 Quinn SC. AIDS and the African American Woman: The triple burden of race, class and gender. Health Education Quarterly. 1993. Vol. 20(3):305-320.

79 Rao VK. The impact of comorbidity on mortalidade following in-hospital diagnosis of tuberculosis. Chest. 1998; 114(5): 1244-1252.

80 Rocha FMG. Política de prevenção ao HIV/AIDS no Brasil: o lugar da prevenção nessa trajetória. Rio de Janeiro, 1999. [Dissertação de Mestrado Escola Nacional de Saude Pública]

81 Ronald AR. Slowing heterosexual HIV transmission. Infectious Disease Clinics of North America. 1995, 9(2):287-296.

82 Sabino EC, Salles NA, Sáez-Alquézar A, Ribeiro-dos-Santos G, Chamone DF, Busch MP. Estimated risk of transfusion-transmitted HIV infection in São Paulo, Brazil. Transfusion. 1999; 39(10):1152-3.

83 Sadik N. Reproductive health/family planning and the health of infants, girls and women. Indian J. Pediatr. 1997, 64(6): 739-44

84 Santos NJS, Munhoz R. A aids entre as mulheres: reflexões sobre seus depoimentos. In: Parker R e Galvão J (orgs)."Quebrando o silêncio: mulheres e Aids no Brasil". Rio de Janeiro. Relume-Dumará ABIA:IMS/UERJ,1996; parte 2,cap 6:115.

85 Santos NJS. A Aids entre as mulheres no Estado de São Paulo. In: Parker R. e Galvão J (orgs). "Quebrando o silêncio: mulheres e Aids no Brasil". Rio de Janeiro Relume-Dumara: ABIA:IMS/UERJ.1996; parte 1,cap 2:33.

86 Santos NJS, Paiva V, Ventura-Filipe E. HIV positive women, reproduction and sexuality in Sao Paulo. Brazil. Reproductive Health Matters. 1998; Vol 6(12),p31-41. 
87 Secretaria de Estado da Saude de SP - Programa Estadual DST/AIDS Vigilància Epidemiológica - Boletim Epidemiológico ano XIX - n"1. São Paulo, abril, 2001

88 Secretaria Municipal de Saúde de São Paulo - Programa Municipal de DST/AIDS Boletim Epidemiológico de AIDS ano I - nº 1. São Paulo, 1997

89 Siegel K. Lekas HM, Schrimshaw EW. Johnson JK. Factors associated with HIV infected women's use or intent to use AZT during pregnancy. AIDS, Education and Prevention, 2001; 13(3): 189-206.

90 Sorrentino SR, Lebrão ML. Os abortos no atendimento hospitalar do Estado de São Paulo. 1995. Rev.Bras.Epidemiol.1998; 1(3):256-267

91 Stephenson JM, Griffioen A. The effect of HIV diagnosis on reproductive experience. AIDS 1996, 10:1683-1687

92 Sunderland MSW, Minkoff HL, Handte J, Moroso G, Landesman S. The impact of human immunodeficiency virus serostatus on reproductive decisions of women. Obstet Gynecol. 1992; 79:1027-31

93 Szwarcwald CL, Andrade CLT, Castilho EA. Estimativa do número de orfãos decorrentes da AIDS materna, Brasil, 1987-1999. Cad. Saúde Pública, Rio de Janeiro 2000, 16(Sup.1): 129-134

94 Szwarcwald CL, Bastos FI. AIDS e Pauperização: Principais conceitos e evidências empíricas. In: Brasil, Ministério da Saúde, Coordenação Nacional de DST e AIDS. Sobre a epidemia da aids no Brasil: distintas abordagens. Brasilia. 1999. P. 7-19

95 U.S. Department of Health and Human Services - HIV/AIDS Bureau A guide to the clinical care of women with HIV. Jean Anderson (edit). Preliminary edition Washington: Government Printing Office, 2000

96 Ueli Zelhveger J. Wang M R. Schrid B. The male IDU epidemic is closely linked to its secondary epidemic among heterossexual women in Europe 12th World AIDS Conference. Geneva. June28-July3 - 1998. Anais. 
97 Veloso VG High prevalence of HIV infection in low income pregnant women in Rio de Janeiro - Brazil 12th World AIDS Conference, Geneva. June28-July3 - 1998, Anais.

98 Vermelho L. Women with AIDS transmission and prevention strategies. 12th World AIDS Conference, Geneva. June28-July3 - 1998, Anais.

99 Villela WV. Barbosa R Repensando as relações entre gênero e sexualidade In Parker R., Barbosa RM (eds). Sexualidades Brasileiras. Rio de Janeiro. RelumeDumará: 1996

100 Waldvogel B, Morais LCC. Mortalidade por AIDS em São Paulo: dezoito anos de história. In: Secretaria de Estado da Saúde de SP - Programa Estadual DST/Aids - Vigilància Epidemiológica - Boletim Epidemiológico ano XVI n². São Paulo, junho, 1998.

101 Waldvogel B, Morais LCC. O cenário promissor da evolução da mortalidade por AIDS no Estado de São Paulo no final do século XX. In: Secretaria de Estado da Saúde de SP - Programa Estadual DST/Aids - Vigilância Epidemiológica - Boletim Epidemiológico ano XX - n"1. São Paulo, janeiro, 2002 (no prelo)

102 Weeks MR, Schensul JJ, Willians SS. Singer M. Grier M. AIDS prevention for African-American and latina women: Buiding culturally and gender appropriate intervention. AIDS Education and Prevention. 1995; 7(3):251-263.

103 Williams HA, Watkins CE. Risby JA. Reproductive decision-making and determinants of contraceptive use in HIV infected women. Clinical Obstetrics and Gynecology. 1996; 39(2) 333-343 
ANEXO 1 


\section{QUESTIONARIO}

codigo da ontrevistada:

data da ontrevista:

mitrevisador losal da mitrevista

duraçào

1- IDADF

Data de nascimento, dia mès ano:

2. ORIGEM

\begin{tabular}{|l|l|l|l|}
\hline a- Voce nasceu onde? & Cidade e estado \\
\hline b- Seu pai nasceu onde? & \\
\hline c- Sua mà nasceu onde? & \\
\hline
\end{tabular}

d- Há quantos anos uhimamente vocè esta $\mathrm{em}$ São Paulo?

3- RESIDEXCIA:

a- Em que bairro vocè mora?

b- Voci mora numa:

(1) 1-Casa de tijolo ( ) 2-Apartamento ( ) 3-Casa de madeira/Barraco () 4-Quarto

() 5-Casa de apoio

() 88-Outro:

c- Quantos cómodos tem sua casa? (contar: dormitorio, sala, cozinha, banheiro)

4. RELIGIJO

a- Qual sua religião?

() 1 -Catolico ou $\mathrm{D}$

() 2-Espiriza ou $\square$

() 3-Evangélica/cranteprotestante

() 4-limbanda/candomble ou $\mathrm{C}$

b- Qual a importáncia da religiảo em sua vida?

() 1-Muno imponante ( ) 2-lmportante ( ) 3-Pouco importante ( ) 4-Nada importante

5-COR R.ACA (documento)

a- Como vocè definiria sua raca/cor?

() 1-Branca () 2-Preta ( ) 3-Parda () 4-Amarela ( )5-outra

6- EDLCACÃO. PROFISSÃO. RENDA. DEPENDÉNCLA ECONOMICA

a- Até que serie vocè estudou? (anotar a serie do lado)

() 1-Vảo sabe let nem escrever

() \$1-Recém convertida

() 52-Recem converida

( ) 53-Recem converida

( ) 54-Recem converida
() 7-Nào tenho religião

() 88 -Ourro

() 58-Recem convertida ao ourr

( ) 77-Não Quis Responder
() 2-Sabe ler e escrever sem ter ido a escola

() 3-Não complatou a ta serie

( ) 4-Complatou a 4 a scrie

() 5-Nào complaou 8a serie
() 9-Complaou $8 \mathrm{a}$ serie
( ) 10-Nào completou o 30 colegial
( ) 11-Complaou o 30 colegial
( ) 12-Lniversidade incompleto
( ) 13-l niversidade completo
( ) 77-Não Quis responde 
1-. Itualmante voce sta empregada'

( ) -Sim emprego ( ) 2-Sim bico ( ) 3-Não desempregada ( $14-$ Wào aposcntada

() 5-Nunea trabathei() 6-Detental () 7-Estudante

¿- Qual e a atividade enprego atual?

d-O que roes ja fez? (anotar do lado algum ditalhe)
() 2- Junca trabalhei
( ) 8-Gerente Empresana
() 14-ioite danca
( ) 3-Do lar dona de casa
( ) 9-No comctcio (balcão, caixa)
( ) 15-Roga
( ) 4-Domestica diarista
( ) 10-Escritorio
() 16 - Iendasibico
() S-Prostituta
( ) 11-Serviços (beleza. costura. de)
() 17-Superior/univ.
( ) 6-Detenta
() 12-Industria (operaria)
( ) 88-Outras
( ) 7-Ténico Magisterio
() 13-Recepcionisa telefone
( ) 77-Nào Quis Respond

e- Quanto vocé ganha por mès?_(em Reais) ( ) 99-Não sabe ( ) 77-Não Quis

f- No ủhimo mès. quanto somou a renda de todos (inciuindo vocè) que ganham dinheiro em sua casa?

Não sabe () 77-Não Quis Responder

g- Quantas pessoas vivem com essa renda. incluindo vocè?

h-Entào. quantas pessoas moram na mesma casa que vocè. incluindo vocè?

7.EVENTO ESTRESSANTE - questóes sobre eventos estressantes

8-EVEXTO SIGNIFICATIVO-quesdes sobre eventos significativos?

\section{9-FAIIILIA}

a- Voce tem filhos?

( ) 1 Sim

( ) $2+\mathrm{NaO}$

( ) 99-Não se aplica

\begin{tabular}{|l|l|l|l|}
\hline b- Idade (No.) & e-Sexo $(F / M)$ & d- Moram com voce? $(\mathrm{S} / \mathrm{N})$ & e- HIV-(S/N) \\
\hline & & & \\
\hline
\end{tabular}

f- De quantas pessoas você cuida. excluindo vocè? (comida. roupa. limpeza. doença)
g- Alguem ajuda?
( ) 1-Sim Quem

( ) 2-Nào

h- Vooe tem parceiro/a fixo/a? () 1-Sim

( ) 2-Nào

i-Como define seu "estado conjugal" parceria sexual ?

() - mora junto

( ) viuva de AIDS sem parceiro

() - casada

() - viuva - outros motivos - sem parceiro

( ) - namora ou caso fixo

(). separada sem parceiro

() - viuva de AIDS com novo parceiro

() - sohteira sem parceiro

() - varios parceiros (mora junto easada namora)

( ) - varios parceiros ( sohteira viuva separada)

j- Seu parceiro atual e positivo?

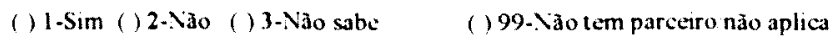




\section{0-PERCEPC IO DE RISCO. ESTIGMAIE TESTE HII}

a- Vocé antes de ir fazer o teste ja tinha pensado que podia set posuiva?

() 1-Sim + 12-Não

b-Por que?

c- Ha quanto tempo voce sabe que e HIV +?

d. Como voce ficou sabendo que era HIV? (anotar a historia. mas as cat egorias que surgiram foram

e- Como voce se sentiu?

f- Como se sentiu em relaçào ao marido / namorado / parceiro parceiros'?

g- Qual voci acha que foi o caminho do virus ate voce??
( ) 1-Mau parceiro se infectou em transfusão
() 7-Recebi uransfusào de sangue
() 2-Meu parceiro usa va drogas
( ) 8-Parceiro me contaminou nào sei como ele pegou
() 3-Marido/namorado teve outros parceiros homens
(1) 9-Marido/namorado teve outros parceiros. não sei se homem ou mulher
() 4-Marido/namorado teve outras parceiras mulheres
( ) 10-Parceiro anterior a esse me infectou
() S-Eu usei drogas injaáveis
( ) $99 \cdot$ Não sabe
() 6-Tive muitos parceiros
( ) 88-Outro

h- Voce fez o teste porque:
() 1-. ledico pediu - porque parcero HIV+/AIDS
() 6-Firma exigiu
( ) 2-Medioo pediu - rotina pre-natal
() 7-Doer sangue
() 3-Medico pediu - porque filho HIV/AIDS
( ) 8-Decidi ir fazer sem médico pedir/
() 4-Medico pediu - porque eu adoeci. fiquei com uma infecăo percebi que tinha possibilidade de ter pego o HIV
() S-Fizeram sem me avisar
( ) 9-Meu marido pediu
( ) 88-Outro

() S-Fizeram sem me avisar

i- Antes de fazer o exame vocè

() 1- Teve uma sesş̃o de conversa com um profissional só sobre o teste

( ) 2- Lma sessão de grupo sobre o teste

( ) 3. O medico conversou bastante comigo

() 4-O medico conversou um pouco comigo

( ) 5. Não tive nonhum aconsethamento

( ) 88 - Ounro

j- Para receber o resultado do exame

() 1 - Fui sozinha

() 2- Fui com uma pessoa amiga ou da familia

( ) 88- Ouro

k- Ao receber o resultado

( ) 3-Recebi o resultado do medico e ele procurou me ajudar

() 4- Recebi do medico e me senti mal tratada

() 5- Recebi do médico que me encaminhou para uma consuta com um outro protissional de saude psicólogo

( ) 6-Recebi de um outro protissional que me maluratou

( ) 7-Recebi de outro profissional que procurou me ajudar

() 8-Recebi uma carta no laboratorio

( ) 9-Recebi do medico que me deu tratamento medico

( ) 88-Ouno 
Depors que soce recebeu o resuhado do exame. quanto tempo voce levou para.

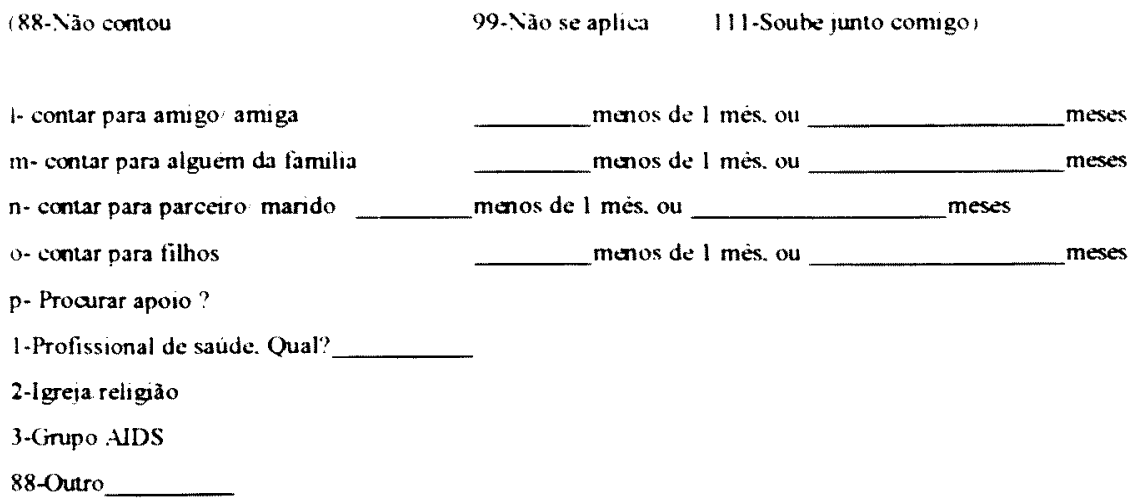

88-Outro

\section{1-HISTORIA SEXT:AL HISTORIA OBSTETRICAE CONTRACEPTIVA}

Agora vamos falar um pouquinho de sua vida mais imima. Espero que vocè se sinta à vontade de falar sobre sexo. filhos comigo ... Sente? $\mathrm{O} . \mathrm{K}$

1- Voce sente vontade de fazer sexo? (Investigar, porques. comos)

b- Vocé tem alguma dificuldade ou dúvida nessa area?

c- Vocè tem relaçðes sexuais com seu pareeiro fixo (sobre ourros parceiros a gente pergunta ja)?
() 1-Sim
( ) 2-Não
( ) 99.Não se aplica/não tenho parceiro

\section{d- Com que frequéncia?}
() -Menos de uma vez por mès
( ) - - uma vez por semana
() -Nào se aplica
( ) -De 1 a 3 vezes por mes
() - Mais de uma vez por semana

¿- Vocés usam algum tipo de precauçio contra o HIV? Qual?
( ) -Nảo
() -Sim camisinha na matoria das vezes
() - Viào se aplica
() -iào. somos os dois HIV.
() -Sim camisinha todas as vezes
() -Oruro
() -Sim. camisinha rarament
() -Sim. fazemos sexo sem penceraça

i- Se nào. porque?

g- Voce tem mais de um parcero sexual?

() $1-\operatorname{Sim}$

( ) 2-Nào 
h. Se sim. wom ester s outros s wee toma alguma presuluio contra ofll

() 1 Nảo

() 4-Sim. camsinha na matoria das vezes

() $99-\mathrm{Na}$

( ) 2-Não, somos os dois HIV.

( ) 5 -Sim camisinha todas as vezer

1) 3-Sim. camsinha raramente

() 6-Sim. tazemos sexo sem pentaraça

- Voce pans em ter fithos"

$(1+\operatorname{sim}$

$2+130$

y. Por qué?

h. Como voce acha que sena a reapo das pessoas que te cercam se voce docidisse tor fithos? (famulua amgos medioos. viznhos. ac)

1. Voce concorda com eles?

m- Vocé ficou gravida depois de exar HIV + ? (Se cla já teve algum evento reprodunivo no periodo pos diagnostico. levantar sobre o contexto da decasao de ter ou nato ter ofitho: como se sentiu. como reagu o profissional de saude como reagu familia. como se sente agora

n- Yox usava algurn metodo anti-oncoptwo fexplicar l para evnar fitho antes de se sabt ponadora do HIV"

(1) Sim $12 \times \mathrm{Nal}$

"se SIM Qual?

\section{(1) Condom}

() 2-Conto unterrompido

( ) 3-Tabela

( ) 88-Outro
( ) 4-Pilula

() 5-Injegho hormonal

() 6-Esterilizada
(1) 7-DIC

() 8-Vaseatoma do parceiro

() 9-Diafragma

p. Voce usou anti-conceptivo para evnar filho depois de se saber ponadora do HIV?
() I-Sim
() 2-Nao
() 99-N3o aplio

9- Se SIM Quas"
1 Condom
() 4-Pilula
(1) 7-DIL"
(1) 2-Cono intertompido
(1) 5-lnjecto hormonal
(1) 8-Vasearoma do parceiro
(i) 3-Tabela
(3)-Estenlizada
() 9-Diafragma

( ) 88-Ouero

r- Nguma crianga ou nene morreu?

() 1 -Sim

() 2-Na

\begin{tabular}{|c|c|c|c|}
\hline & de que? & quantos? & quando? \\
\hline Expontaneo $1-7$ meses: & & & \\
\hline Satmonat -7meses: & & & \\
\hline Veomono inasced bi o morteu & & & \\
\hline Vivea - de 28 das e daposs morreu & & & \\
\hline
\end{tabular}

- Quantos abonos provocados:

1- Sais ou menos quantas vezes voce fez pre-natal na sua utuma gavidez?
consuha(s)
() 99-Nao aplica 
u- Que idade voce tinha quando voce teve sua primeira relaçào sexual?'

$\checkmark$ - Vocè queria ter essa primeira relaçào sexual?
( ) $1-\operatorname{Sim}$
( ) 2-Não
( ) 88-outro (qual'?)

x- Quantos parcetros sexuars voce tete ate hoje?
( ) 99-Muritos. nào sabe
Exatos.
ou. Mais ou menos

y- Quantos foram teu parceiro tixo (namorado. companherro. marido. noivo)?

Z- Na sua vida até hoje, vocé foi forcada a fazer sexo contra a sua vontade'?

() 1-Muitas vezes, não lembro () 2-Poucas vezes () 3-Nunca ( H- Uma vez

w- Na sua vida até hoje. vocé foi forcada com violéncia a fazer sexo contra sua vontade?

() 1-Murtas vezes. não lembro () 2-Poucas vezes () 3-Nunca ( H-Uma vez ww- Foi com alguem que vocè conhecia antes?
( ) $1-\operatorname{Sim}$
( ) 2-Não
( ) 99-Não se aplica

www- Porque você acha que isso aconteceu?

wwww- Vocè ja fez sexo em troca de dinheiro. presentes favores?

() 1-Muitas vezes. não lembro () 2-Poucas vezes () 3-Nunca () 4-Uma vez wwwww- Porque?

12-ACESSO E RELAC ÃO COM SISTEMA DE SAUDE - questóes relacionadas a satisfação e diticuldades no atendimento

\section{3-ATITUDES E CONHECIMENTO SOBRE OS CUIDADOS COM A SAUDE}

a- $\mathrm{O}$ que vocè acha que é ser portador do virus HIV?

b- O que vocè acha que è ter AIDS?
c- Você sabe o que é o exame de CD4?
() 1 -Sim
( ) 2-Não

d-O que é?

e- Quando vocè fez o último exame de CD4?

f- Qual foi o resultado?

() 99-Não sabe

g- Vocé sabe o que è o exame de carga viral?

( ) 1-Sim ( ) 2-Não

h. O que é?

i- Vocè já fez?

() 1-Sim Quando? ( ) 2-Não

j- Qual foi o resultado?

( ) 99-Nào sabe

$k$ - $O$ que voce acha que e o coquatel?

1- Quando é que vocè acha que alguém deve começar a tomar?

m- Vocè conhece os efétos do remédio (beneficios. efeitos colaterais)?( ) 1-Sim( ) 2-Não

n- Quais såo?

\section{4-ADES ÃO AS RECOMENDACÕES DE PREVENC IO SECLTDARIA}

a- Em termos gerais. nos uhtimos 30 dias. como descreveria seu estado de saúde?
() 1-Órimo
( ) 2+Bum
( ) 3-Não muito bom
( ) 4-Ruim

Descreva seu exado de saude em palavras:

b-Como esteve set apain nos úhimos 30 dias'?
( ) 1-Oximo
( ) 2-Bom ( ) 3-Não muito bom
( ) 4-Ruim 


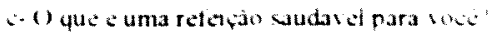

d- Voce comer uma refeica saudavel por da tna uhama semanal

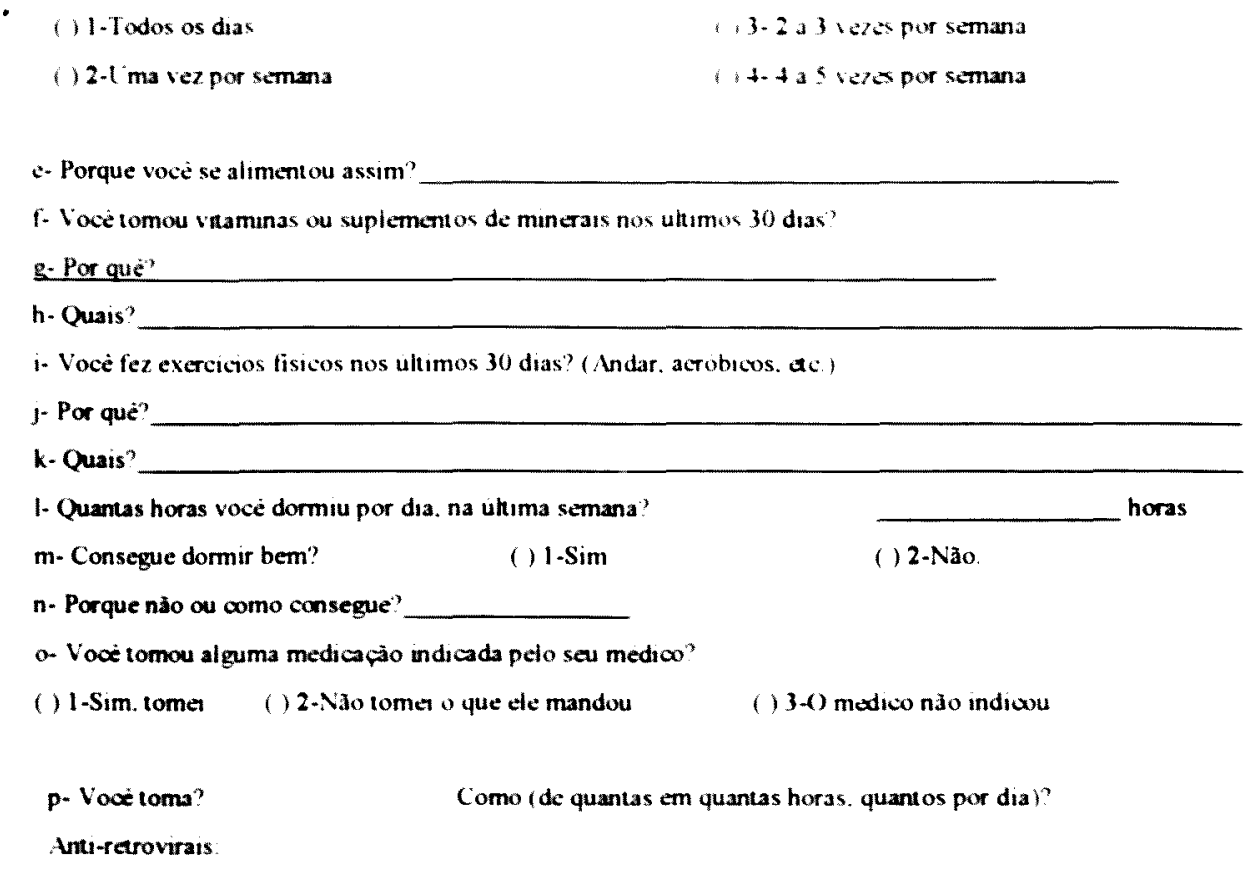

q- Que efeno este remedio tem na sua saude (especificar o remedio)?

r- Vocé organiza a sua alimentacio em funclo dos remedios? () 1-Sim ( ) 2-Nao

Como?

s- Fez algum tratamento altemativo caseiro? () 1-Sim () 2-Nåo

1- Tomou alguma medicaca de farmacia por conta propria?

() 1-Sim - Quem reoomendou? () 2-N1o

U-Em relagio a medicaplo que tomou por conta propra. voce informou o medico?
( ) 1-Sim
() $2 \cdot \mathrm{Nazo}$

v- Esta usando outros matodos de tratamento e ajuda?(Oraço. remedios espirituais. trabalhos de candomble. visitas a espiritas) ( $12+\mathrm{NaO}$ 
15-FONTES DE IPOIO

3. Vocé pensa muno em qua vocé é HIV'+?

b- O que mantem voce lutando?

- Pensando em que exista a possibilidade de vocé faltar aos sous filhos. ja pensou como meaminhar as coisas em rela äo a eles?

d. O que voce gostana de receber como aporo. ajuda. colaboraglo. sen ipos para melhorar sua qualidade de vida?

a- Voce pode dizer o que vem primetro. segundo. teteero. ac?

f. Que tipo de apoio organizado voce prefere (mais de uma opplo)

() 1 - Eu prefiro o mais perto possivel da minha casa.

() 2- Eu prefiro mais distante da minha casa.

( ) 3- Eu prefiro ajuda individual

( ) - Eu prefiro me encontrar com um grupo.

() 5 - Eu prefiro um grupo de mulheres.

() 6- Eu prefiro um grupo que tenha homens e mulheres.

() 88 -Outro

g- Tem algum tipo de pessoa que nào te deixaria contona vel no grupo?

h-Agora cu vou ler para voce o nome de alguns grupos de apoto e o que eles se propoje a fazer. Me diga o que voce acha de cada um. (listar os que existem) OBRIGADA:: 
ANEXO 2 
Numero do Ptontuario

Número da Entrevista

\section{CONSENTIMENTO PARA PARTICIPAR DA PESOUISA}

\section{A- Identificaçào e Proposta}

Vera Paiva. Prof. Dra da Lniversidade de Sào Paulo. a Dra. Naila Santos do CRTA (Centro de Referência c Tratamento em AIDS) e o Dr. Norman Hearst Universidade da Califórnia cstào conduzindo este estudo para pesquisar diversos aspectos da infecção pelo HIV nas mulheres e as maneiras para apoiar as mulheres HIV positivas em São Paulo.

\section{B- Convite e Recusa}

Eu estou sendo convidada a participar deste estudo. assim como todas as mulheres que estão vindo neste periodo ao ambulatório do CRTA.

Eu sei que a participaçào neste estudo é absolutamente voluntána. Eu tenho o direito de recusar a participar ou desistir em qualquer ponto deste estudo. Minha decisão $\mathrm{em}$ participar ou nào desta pesquisa não terá influència em meus direitos de ter um tratamento de saúde de boa qualidade e não prejudicará meu atendimento.

\section{C- Procedimentos}

Se eu concordar em participar deste estudo. o seguinte ocorrerá:

Uma entrevistadora irá me fazer perguntas previamente escritas num questionário. ela irá ouvir minhas respostas e anotá-las. Esta entrevista será realizada em um ambiente que somente eu e a entrevistadora escutemos o que eu estarei respondendo. As perguntas serão sobre meu estado de saúde. minha familia e amigos, minha relação com o sistema de saúde. as situações boas e ruins que eu tenho enfrentado em relação ao HIV/AIDS e minhas práticas relacionadas a AIDS e reprodução. Algumas destas perguntas serão muito pessoais. incluindo questðes sobre práticas sexuais. A entrevista terá duração aproximada de $1 \mathrm{~h} 30 \mathrm{~min}$.

Eu escolherei participar em um ou mais grupos oferecidos durante este estudo. O grupo será constituido das mulheres HIV positivas que são atendidas no CRTA. e que estão participando desta pesquisa. Uma ou mais facilitadoras da USP. do CRTA e do UCSF estará presente nos grupos.

Cada inicio de sessão de grupo. retomaremos o compromisso de respeito às diferenças de opiniảo. e de manter nomes e histórias compartilhadas. confidenciais.

Ao final. eu serei convidada a avaliar os grupos. como eles afetaram a minha vida e a relevancia das questões trabalhadas no grupo. Discutiremos tambem a contunuidade.

\section{D- Risco/Desconforto}

Nảo há nenhum efeito prejudicial antecipado em participar da pesquisa. Algumas perguntas são pessoais e delicadas. Se alguma questào me deivar chateada ou desconfortável. eu sou livre para me recusar a responder a qualquer momento

Sigilo

Meus dados serảo guardados e usados o mais confidencialmente possivel. Nenhuma identidade pessoal será usada em qualquer relato ou publicação que possam resultar do estudo. Nenhum nome será associado ao questionário. O questionário terá um número nele e somente a Prof. Vera Paiva da USP terá acesso à lista que pode associar o numero à pessoa. Esta lista ficará trancada em lugar diferente dos questionánios. Os questionários serjo destruidos depois que o estudo terminar 


\section{E- Beneficios}

Eu terei a oportunidade de receber sessão de aconselhamento e participar de un grupo de mulheres num periodo de maior conveniència para mim. sem estar em fila. Além disso eu receberei R\$10.00 como reembolso por minha participação $\mathrm{em}$ responder o questionário.

\section{F- Questão}

Se eu tiver alguma questão ou comentários sobre a participação neste estudo. eu posso falar com a Prof. Vera Paiva. na Universidade de São Paulo (USP).

O endereço é

Prof. Vera Paiva

Instituto de Psicologia USP- Av.. Prof. Mello de Moraes. 1721- Cidade Universitária- São Paulo005508-900

O telefone do Instituto de Psicologia é \#818-4184

\section{G- Consentimento}

Eu conversei com sobre o estudo e foi dada uma cópia deste consentimento para mim. Eu entendi o que li ou o que ouvi e tive minhas perguntas respondidas. A participação neste estudo ć voluntária. Eu sou livтe para recusar estar no estudo ou desistir a qualquer momento. Minha decisão não irá afetar meus direitos de receber os serviços aqui ou em qualquer outro serviço público.

Data:

Assinatura da Participante entrevistadora

Endereço para o seguimento: 